\title{
Historic Sites Reconnaissance of the Oak Ridge Reservation Oak Ridge, Tennessee
}

\author{
George F. Fielder, Jr. \\ Steven R. Ahler \\ Benjamin Barrington
}

\section{OAK RIDGE NATIONAL LABORATORY}

OPERATED BY UNION CARBIDE CORPORATION FOR THE ENERGY RESEARCH AND DEVELOPMENT ADMINISTRATION 


\section{DISCLAIMER}

This report was prepared as an account of work sponsored by an agency of the United States Government. Neither the United States Government nor any agency Thereof, nor any of their employees, makes any warranty, express or implied, or assumes any legal liability or responsibility for the accuracy, completeness, or usefulness of any information, apparatus, product, or process disclosed, or represents that its use would not infringe privately owned rights. Reference herein to any specific commercial product, process, or service by trade name, trademark, manufacturer, or otherwise does not necessarily constitute or imply its endorsement, recommendation, or favoring by the United States Government or any agency thereof. The views and opinions of authors expressed herein do not necessarily state or reflect those of the United States Government or any agency thereof. 


\section{DISCLAIMER}

Portions of this document may be illegible in electronic image products. Images are produced from the best available original document. 


\section{Printed in the United States of America. Available from National Technical Information Service \\ U.S. Department of Commerce \\ 5285 Port Royal Road, Springfield, Virginia 22161 \\ Price: Printed Copy $\$ 5.50$; Microfiche $\$ 3.00$}

This report was prepared as an account of work sponsored by the United States Government. Neither the United States nor the Energy Research and Development Administration/United States Nuclear Regulatory Commission, nor any of their employees, nor any of their contractors, subcontractors, or their employees, makes any warranty, express or implied, or assumes any legal liability or responsibility for the accuracy, completeness or usefulness of any information, apparatus, product or process disclosed, or represents that its use would not infringe privately owned rights. 
Contract No. W-7405-eng-26

ENERGY DIVISION

HISTORIC SITES RECONNAISSANCE OF

THE OAK RIDGE RESERVATION

OAK RIDGE, TENNESSEE

George F. Fielder, Jr. Steven R. Ahler Benjamin Barrington

Department of Anthropology

University of Tennessee

Knoxville, Tennessee

August 1976

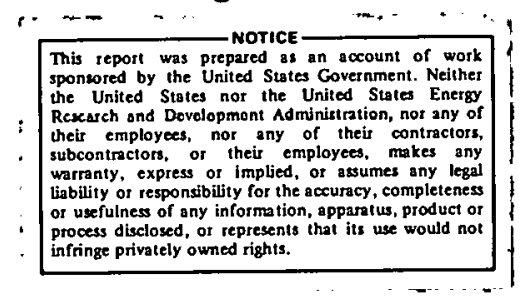

Project Conducted and Reported in Accordance with Union Carbide Corporation, Nuclear Division Subcontract 4419

Date Published: April 1977

OAK RIDGE NATIONAL LABORATORY

Oak Ridge, Tennessee 37830 operated by UNION CARBIDE CORPORATION

for the

ENERGY RESEARCH AND DEVELOPMENT ADMINISTRATION 
THIS PAGE

WAS INTENTIONALLY

LEFT BLANK 


\section{ABSTRACT}

The Oak Ridge reservation area, acquired by the U.S. Corps of Engineers for the Manhattan Project in 1942, was a typical portion of the ridge-and-valley section in eastern Tennessee, containing approximately 1000 individual land tracts complete with farmsteads, schools, churches, and communities. In compliance with Executive Order 11593, Union Carbide Corporation, Nuclear Division, contracted with the University of Tennessee Department of Anthropology to locate, record, and assess the historical significance of the extant buildings and structures that predated Federal acquisition and are now located on Federal land.

Four hundred fifteen structures and structure sites were located, recorded, and evaluated as to their architectural and historical significance. Of that number, 215 no longer have any physical evidence remaining, 115 are represented by foundation remains, 46 are partially standing, and 41 are standing structures.

Selected structures were recommended for on-site preservation through periodic maintenance and others for possible relocation to less hostile or more compatible surroundings. One structure, a double-pen $\log$ house constructed in the early 19th century, was recommended for nomination to the National Register of Historic Places based on architectural and historical significance. Three grave structures, one of them of $\log$ construction, were recommended for on-site preservation through periodic monttoring and maintenance. 


\section{THIS PAGE}

\section{WAS INTENTIONALLY LEFT BLANK}




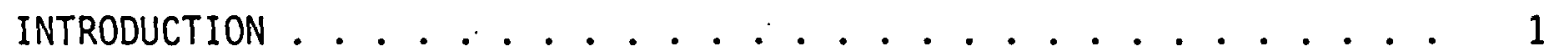

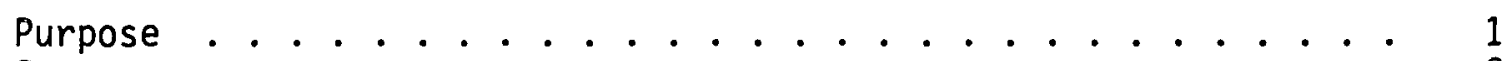

Scope ....................... 2

Further Research . . . . . . . . . . . . . 2

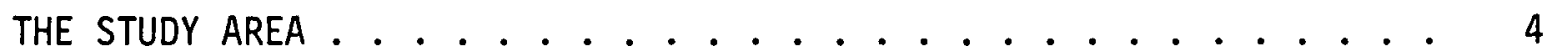

Location .................... . . . 4

Physiography ................... . . 4

Settlement History ................ . . 4

PREVIOUS RESEARCH .................. 6

Clinch River Breeder Reactor Plant . . . . . . . . . . . 6

Archaeological Survey of the Oak Ridge Reservation . . . . . . 6

Exxon Nuclear Company Proposed Bear Creek Plant Site . . . . . . . 7

Possible Expansion Area at ORGDP Site ........... 7

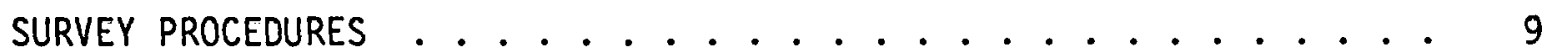

Documentary Sources Consulted . . . . . . . . . . . . 9

Field Methods . . . . . . . . . . . . . . . 10

Areal Coverage .................... 11

Disposition of Field Records .............. 11

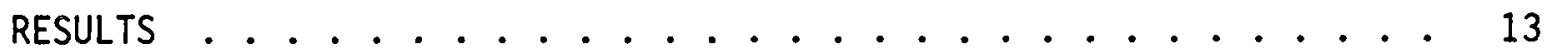

Summary of Physical Condition of Located Structures . . . . . 15

Structure Descriptions .................. 16

Geographical Distribution of Extant Structures ........ 16

DISCUSSION OF RESULTS .................. 21

RECOMMENDED DISPOSITION OF RECORDED STRUCTURES . . . . . . . 23

Recommendation Categories ............. 23

Field Recommendations .............. . . 25

CONCLUSIONS ........................... 40

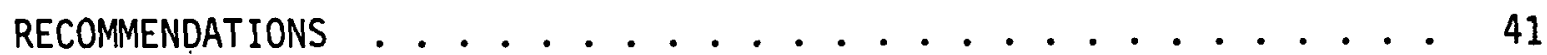

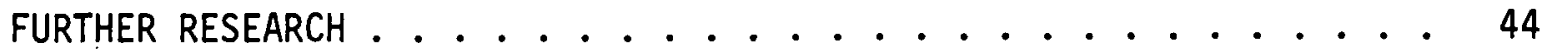

REFERENCES CITED ........................ 45 
$v i$

Page

APPENDIX A: INVENTORY OF RECORDED INVESTIGATED STRUCTURES . . . • 46

APPENDIX B: COPY OF THE RECONNAISSANCE RECORDING FORM . . . . . . . 81 


\section{INTRODUCTION}

This study of the pre-1942 structures and buildings now located within the boundaries of the ERDA Oak Ridge area is a direct result of a survey of the prehistoric archaeological sites of the area conducted in 1974 (Fielder 1974). During the 1974 survey, the field party encountered several examples of standing log structures dating from the early nineteenth century occupation of the Oak Ridge area. The survey report recommended that a survey be conducted of the extant historic sites and structures to evaluate any such remains or buildings in compliance with Federal historic preservation policy (Fielder 1974:82).

Following that recommendation, such a survey was undertaken by personnel from the Department of Anthropology, University of Tennessee, Knoxville, under Union Carbide Corporation, Nuclear Division, Subcontract No. 4419. Under the overall direction of George Fielder, Jr., Research Associate, Department of Anthropology, the field work was conducted by Steven Ahler and Ben Barrington during the period 1 July to 31 August 1975. The final report was written by George Fielder, Jr. Marion Drescher drafted the figures, and Dorothy Fielder typed the final copy.

\section{Purpose}

The primary purpose of the present reconnaissance was to locate, inventory, and evaluate extant historic sites and structures on the Federally controlled portion of the Oak Ridge area pursuant to national policy concerning the protection and conservation of our cultural resources. A summary statement of the current Federal historic preservation policy can be found in the Federal Register. 


\section{Scope}

The areal extent of the current study included the portions of the reservation that are under Federal control. It did not include the areas that have been investigated and evaluated as part of specific proposed impact areas (Fig. 1). These other proposed projects are discussed below in the section on previous research (p. 6). All known structure locations within the study area boundary were examined by the field party.

\section{Further Research}

Although this report is final in terms of the contract agreement (Subcontract 4419), it does not address itself to, nor exhaust, the folk cultural aspects of the data generated by the reconnaissance. The primary intent of this report is the evaluation of extant structures and recommendations for the their preservation and disposition. The information on traditional building practices recorded by this survey will be synthesized and incorporated into local and regional studies of the folkways of the Southern Appalachian area. In addition, the results of this survey will add to the historic sites and structures data base in the southeastern United States.

No further work is anticipated to meet the information needs of Oak Ridge Operations Office of the Energy Research and Development Administration project to evaluate the environmental effects of ERDA operations on the Oak Ridge site, a study conducted by the Energy Division of Oak Ridge National Laboratory. 


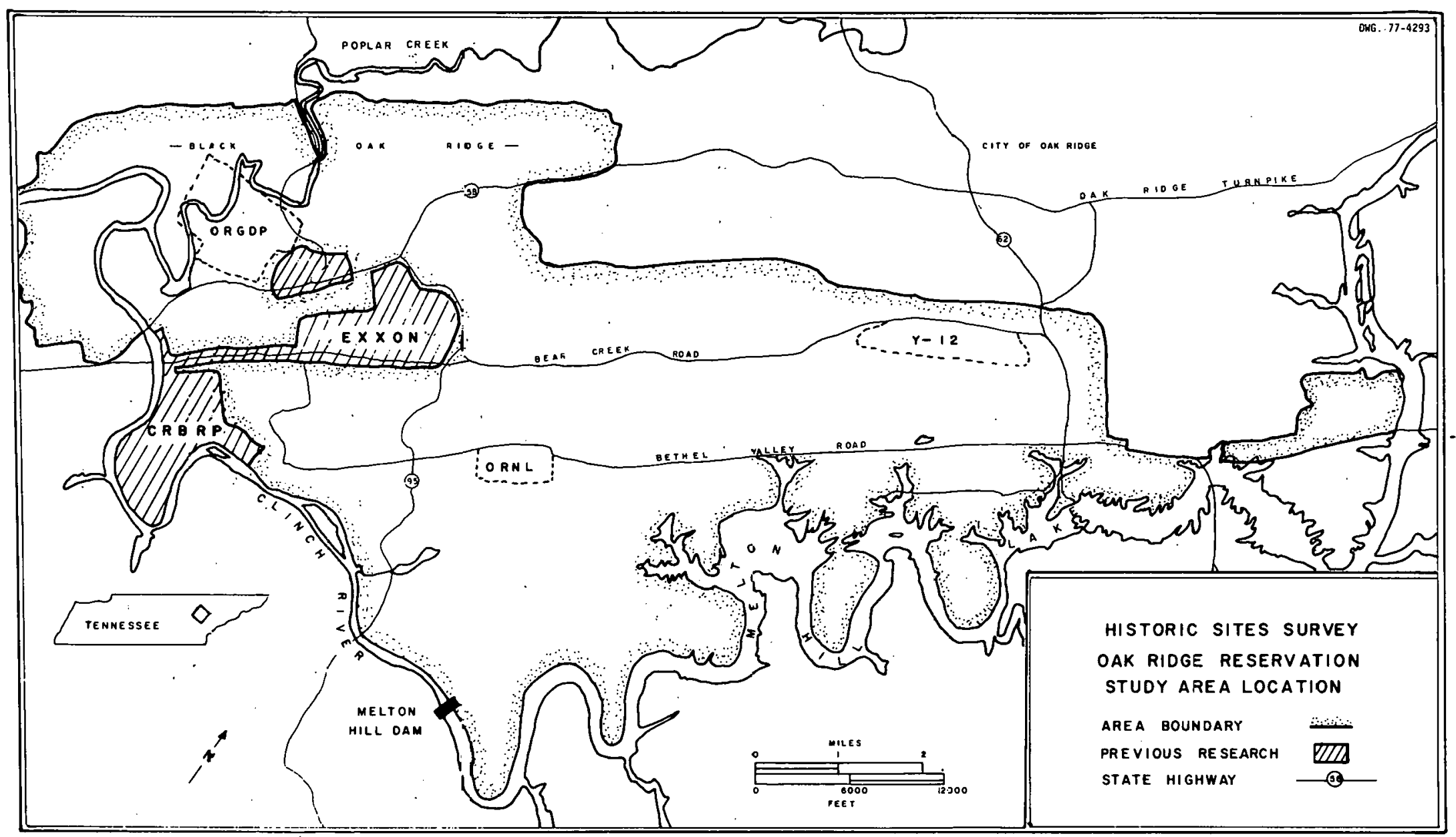

Fig. 1. Location of Study Area. (Base map: Oak Ridge Area S16A [1974]). 
THE STUDY AREA

\section{Location}

The Oak Ridge reservation, located in eastern Tennessee, occupies portions of Anderson and Roane counties. It is bounded on the east, south, and west by meanders of the Clinch River; the north boundary is oriented parallel to Black Oak Ridge (Fig. 1).

\section{Physiography}

The area is located in the Ridge and Valley physiographic province which lies between the Appalachian Mountains and the Cumberland Plateau. Characterized by series of parallel abrupt ridges and narrow valleys, the topography influenced land-use patterns and other cultural features. For example, the highway patterns generally follow the valleys and cross the ridges infrequently. The ridges were usually forested and the valleys cleared for agricultural use. In the present 0ak Ridge reservation, regrowth, both natural and planted, covers the old cleared areas.

\section{Settlement History}

The following comments on the Euroamerican settlement of the Oak Ridge area are very brief and do not represent research of primary documents or sources. No detailed historical studies of the Oak Ridge area prior to Federal acquisition has been made to present. However. several general publications concerning selected aspects of the local history have been prepared. Clifford Seeber (1928) wrote a history of Anderson County; Snyder Roberts prepared a history of the Roberts family of Roane County, including those Roberts who occupied the portion of the 
reservation acquired for the present Oak Ridge Gaseous Diffusion Plant (Roberts 1969). In a popular book on the history of the Manhattan Project and Oak Ridge, Robinson (1950) devotes one chapter to the area prior to Federal acquisition.

The area was first settled in the late 1700's and continued as a basic agrarian economy until 1942 (Roberts 1969; Robinson 1950). By this time there were about 1000 families ( 3000 persons) living in the immediate area affected by the Manhattan Project (Robinson 1950:29). U. S. War Department final land acquisition records list a total of 866 land tracts acquired (U. S. War Department 1942-45). Names of many of the previous property owners are listed in Appendix B, along with a description of existing structures.

of the four communities in the area--Elza, Robertsville, Scarboro, and Wheat--only the latter two were included in the present study area. Scarboro was located along Bethel Valley Road at the present location of UT-CARL administrative offices; Wheat was a thriving community located near the present intersection of Oak Ridge Turnpike and Blair Road east of ORGDP. 


\section{PREVIOUS RESEARCH}

Prior to 1972 there had been no scientific investigation of the historic sites and structures on the reservation. Since this time, however, several studies have been performed in conjunction with the evaluation of potential impact of specific Federally supported or licensed construction projects under the requirements of the National Environmental Policy Act of 1969. These previous studies are discussed below.

\section{Clinch River Breeder Reactor Plant}

Part of the assessment of potential environmental impact of the proposed Tennessee Valley Authority-Project Management Corporation breeder reactor plant project involved an archaeological survey that determined possible adverse impact on prehistoric and historic period archaeological sites (Schroed1 1972). The project area is located on the southwestern corner of the Oak Ridge reservation and is part of an area under the jurisdiction of the Tennessee Valley Authority (Fig. 1).

As part of the mitigation of adverse impact, the historic period structures were located and inventoried (Thomas 1973; Schroedl 1974). The results of research in the CRBRP area are not included in the present study; the area was not reexamined by the field party.

\section{Archaeological Survey of the Oak Ridge Reservation}

In the spring of 1974, G. F. Fielder, Jr. conducted a survey of the prehistoric archaeological sites on the reservation. In addition to the aboriginal sites reported, two historic period sites were described. 
One was a foundation in the Wheat area representing the remains of a fourcrib log barn (Fielder 1974:69); the other historic site, Freels Cabin, was recommended to be considered for nomination to the National Register of Historic Places (Fielder 1974:29). This cabin, constructed of hewn horizontal logs in a double-pen configuration with a massive, centrally placed, cut 7 imestone chimney and double fireplace, is an excellent example of $\log$ architecture of the early nineteenth century.

\section{Exxon Nuclear Company Proposed}

Bear Creek Plant Site

In conjunction with potential plant site evaluation, the Department of Anthropology, University of Tennessee, Knoxville, investigated the cultural resources in a portion of the 0ak Ridge reservation adjacent to the Clinch River Industrial Park. The study area, located along Bear Creek Road, Pine Ridge, and portions of Clinch River-Watts Bar Lake, was examined for extant prehistoric and historic archaeological sites (Fig. 1). The survey recorded 20 historic structures in the study area. A report of the survey (Fielder 1975a) was submitted to G. R. Kiel, Manager, Reprocessing, Licensing, and Compliance, Exxon Nuclear Company, Richland, Washington. The results of this survey are not included in the present report. The Exxon study area was not reexamined.

\section{Possible Expansion Area--ORGDP Site}

Located adjacent and east of Oak Ridge Gaseous Diffusion Plant, the possible plant expansion area (Fig. 1) was survcycd by G. F. Fielder in June 1975 in order to locate, identify, and evaluate prehistoric and historic archaeological sites or structures in the Wheat community that could be adversely affected by construction activities. The survey report 
recommended that the Roberts Memorial Church and associated cemetery be protected from construction activities and maintained to facilitate public access (Fielder 1975b:28). The results of the possible K-25 expansion site survey are not incorporated into the present report, and the area was not reexamined. 


\section{SURVEY PROCEDURES}

In summary, the survey procedures were quite straightforward. Using cultural features shown on pre-Manhattan Project editions of USGS topographic quadrangle maps (Elverton, Bethel Valley, Windrock, and Lovel1) and a special edition of a planimetric map of the Oak Ridge area prepared by the Tennessee Valley Authority (USTVA 1942), the field crew field checked all of the indicated structure sites. Some of the 1940 roads have been maintained on the reservation so that access to the structure sites varied from easy to difficult.

\section{Documentary Sources Consulted}

Maps

1. Final Land Acquisition Maps.

This set of maps shows acquisition tract boundaries on a planimetric base map. Each tract is numbered with a letter and number. The letter designation indicates the map sheet and the numbers are consecutive within blocks. Block $A$ includes tract numbers 1-100; Block B contains tract numbers 101-200, etc. Copies of this map are on file at the ERDA-ORO offices, Federal Office Building, Oak Ridge, Tennessee.

2. USGS 7-1/2 Minute Series. Topographic Quadrangles.

This series of maps depicts natural and cultural features at a map scale of $1: 24,000$; the Oak Ridge area is covered by the following quadrangles: Bethel Valley, Elverton, Lovell, Windrock, and Crinton. Cultural features, such as structures, are shown as 
stylized map symbols; houses are represented by black squares and barns usually are shown as open squares. Churches, schools, cemeteries, and roads are also shown by specific map symbols. The survey team used copies of the following editions of the applicable topographic maps: Bethel Valley--1941, Elverton--1941, Lovell-1953, Windrock--1952, and Clinton--1952.

3. Kingston Demolition Range Map (USTVA 1942).

Produced by the Tennessee Valley Authority for the Manhattan Project under the code name "Kingston Demolition Range" and compiled from circa 1938 planimetric editions of the Bethel Valley, Elverton, Lovell, Windrock, and Clinton quadrangles, this map shows roads, trails, water features, and structure locations. Copies of this map are presently available from the Tennessee Valley Authority Maps and Surveys Office, Knoxville, Tennessee.

\section{Other Primary Sources}

The ERDA-ORO Photographic Laboratory has a copy of an aerial photomosaic of the entire Oak Ridge reservation made prior to any construction activity. This photomosaic shows individual structures, fence lines, field patterns, haystacks, and other natural and cultural features to a degree unmatched by other available sources. Aithough this photomosaic was used to a limited extent during the current survey, it represents an extremely valuable and irreplaceable source of information on the pre-Manhattan Project cultural landscape.

\section{Field Methods}

Using land acquisition tract maps and circa 1940 topographic maps, each depicted structure was assigned an identification number and 
letter combination. The number referred to the tract number on which it was located; individual structures were assigned letters. For example, four structures--409A, 409B, 409C, and 409D--were examined on Tract 409. This structure identification convention was used previously in the survey of two other areas of the Oak Ridge reservation (Fielder 1975a, 1975b).

The field crew visited each structure site on foot and recorded the extant remains (if present) using a historic structures field recording form adapted from a Canadian Inventory of Historic Buildings survey form. A copy of the field recording form is reproduced as Appendix C. The location of individual structures was determined graphically from the USGS quadrangle maps and recorded as latitude and longitude. In addition to the survey form being filled out, the structure was photographed with color and panchromatic film.

\section{Areal Coverage}

The survey team examined 415 structure locations on 117 tracts. Figure 2 indicates the tracts that were examined; tracts in areas previously investigated (Fig. 1) are not indicated as "examined."

\section{Disposition of Field Records}

The original copies of all field records collected during this survey are stored in the permanent record files of the Department of Anthropology, University of Tennessee, Knoxville. Photographic records are filed in the department permanent photograph file. 


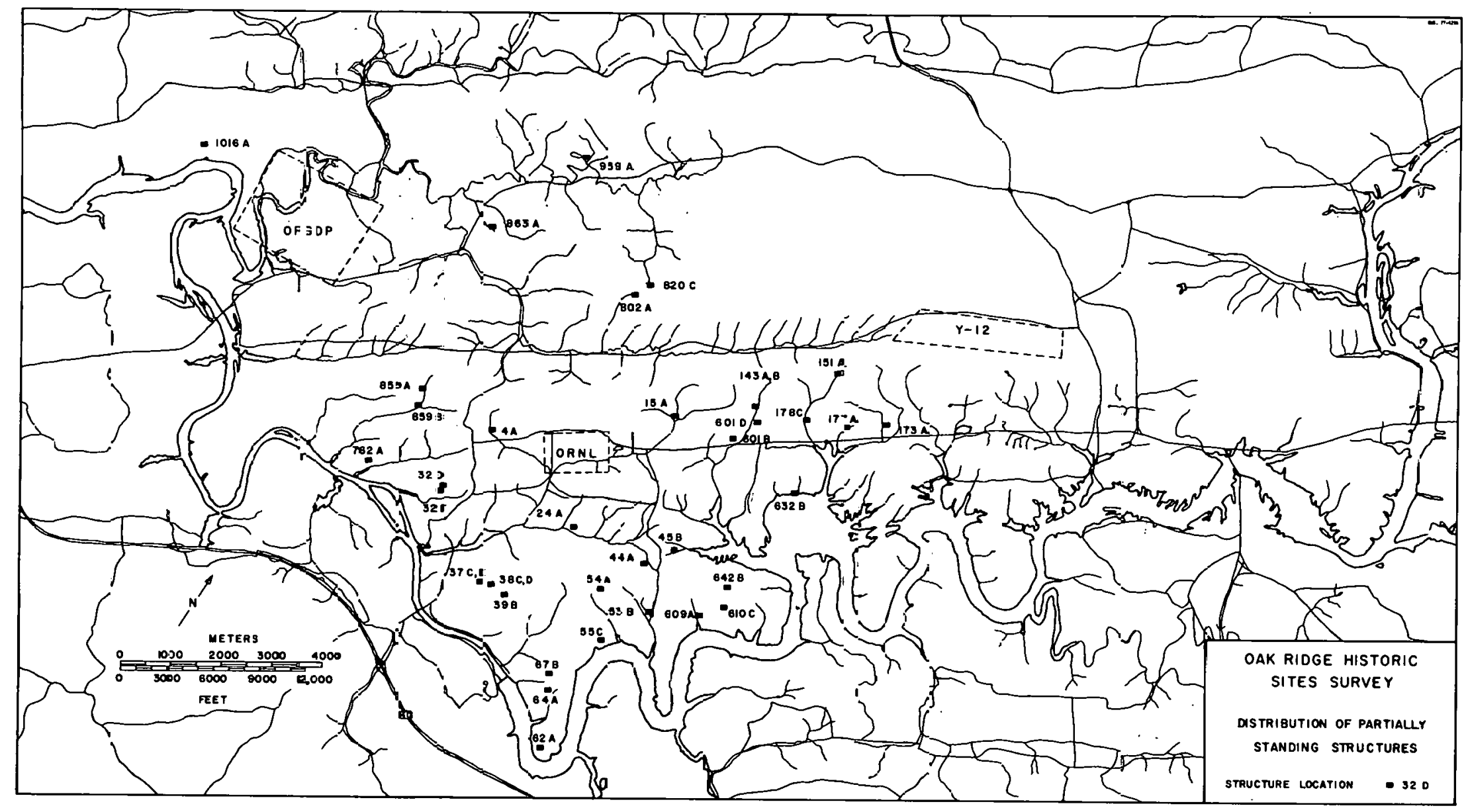

Fig. 2. Land Tracts Examined by the Current Survey. (Base map: U.S. Corps of Engineers Final Land Acquisition Maps 1943-45.) 


\section{RESULTS}

The survey recorded extant buildings in a wide range of existing conditions. The structure conditions were classified into four categories: (1) No physical remains present, (2) foundation only, (3) partially standing structures, and (4) standing structures.

Category 1 includes structures that have been completely razed and/or the structure site has been altered to the extent that the precise original location is not discernible.

Category 2 includes building or structure sites where the fabric of the building (e.g. walls, roof, and other structural elements) has been removed from the site and only the foundation materials remain (Fig. 3). This category includes sites where only the scattered foundation piers or stone rubble from foundations and piers are observable on the surface.

Category 3 includes sites where the building fabric is incomplete. Examples include structures for which one or two of the walls are in their original location but the roof, other walls, etc, are missing or deteriorated (Fig. 4). A structure in which the walls are standing and only the roof has been removed would be classed as belonging to Category 4 .

Category 4 contains structures in which the fabric is essentially intact to the degree that very few construction details are not directly observable. This category includes buildings that can be either preserved in their existing condition (stabilized), restored, or relocated to a new site. 


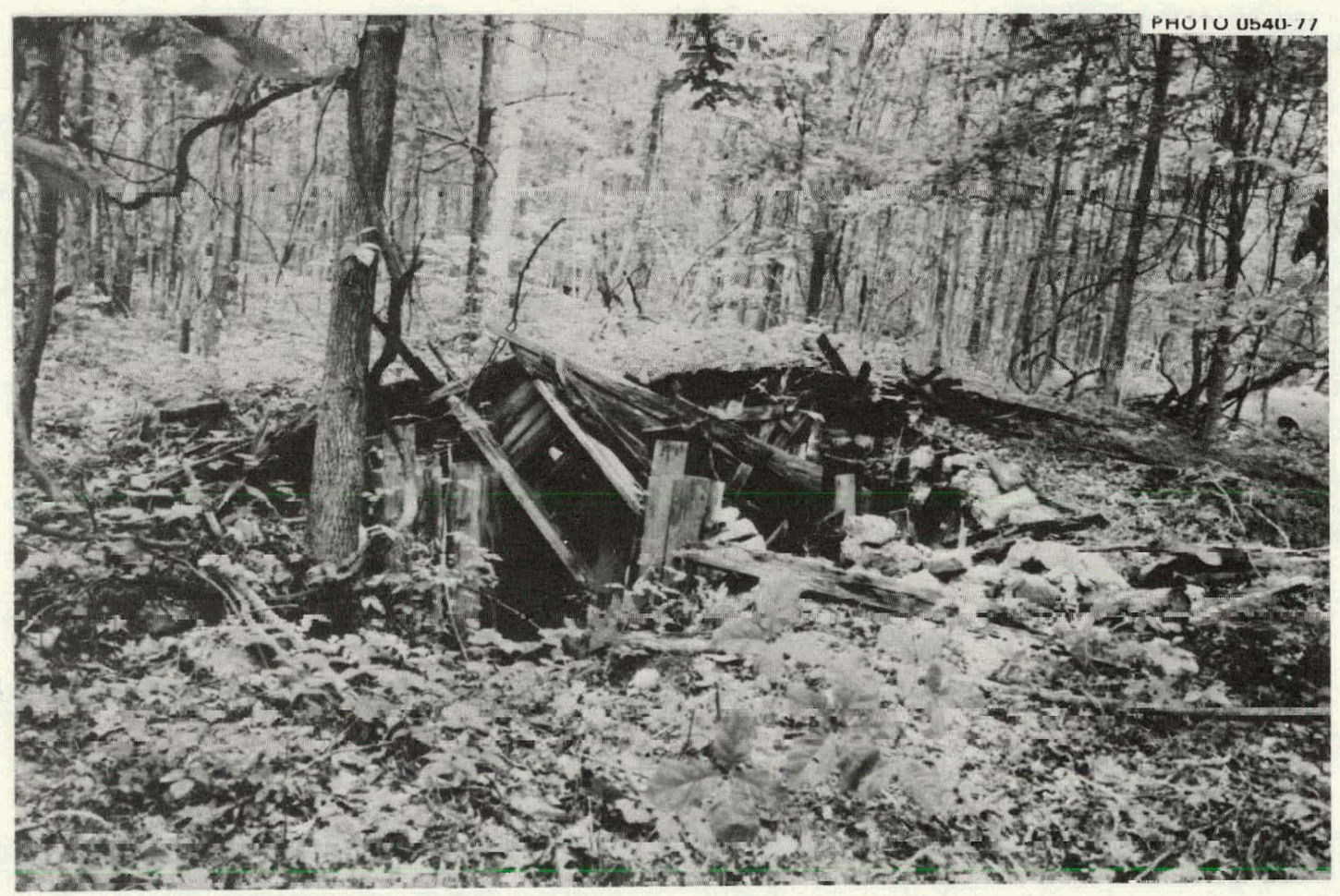

Fig. 3. Example of Condition Category 2--Foundation Only.

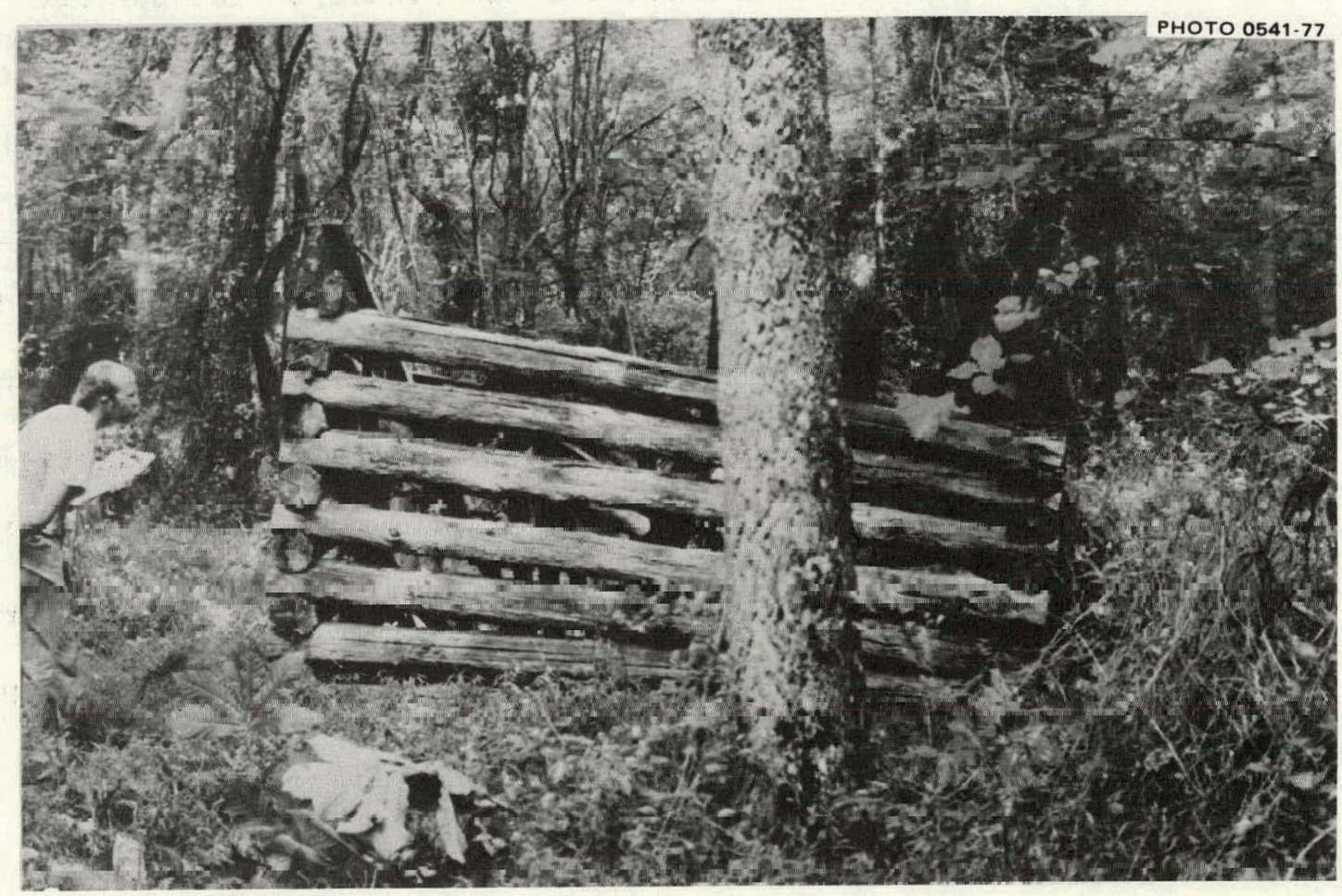

Fig. 4. Example of Condition Category 3--Partially Standing. 
$\frac{\text { Summary of Physical Condition }}{\text { of Located Structures }}$

Condition 1--No Physical Evidence

of the 413 structure locations examined, 215 did not have any physical remains of the structure present.

Condition 2--Foundation Only

The building fabric had been removed from 115 structures, leaving only the foundation remaining. The structures recorded as Condition 2 are listed below:

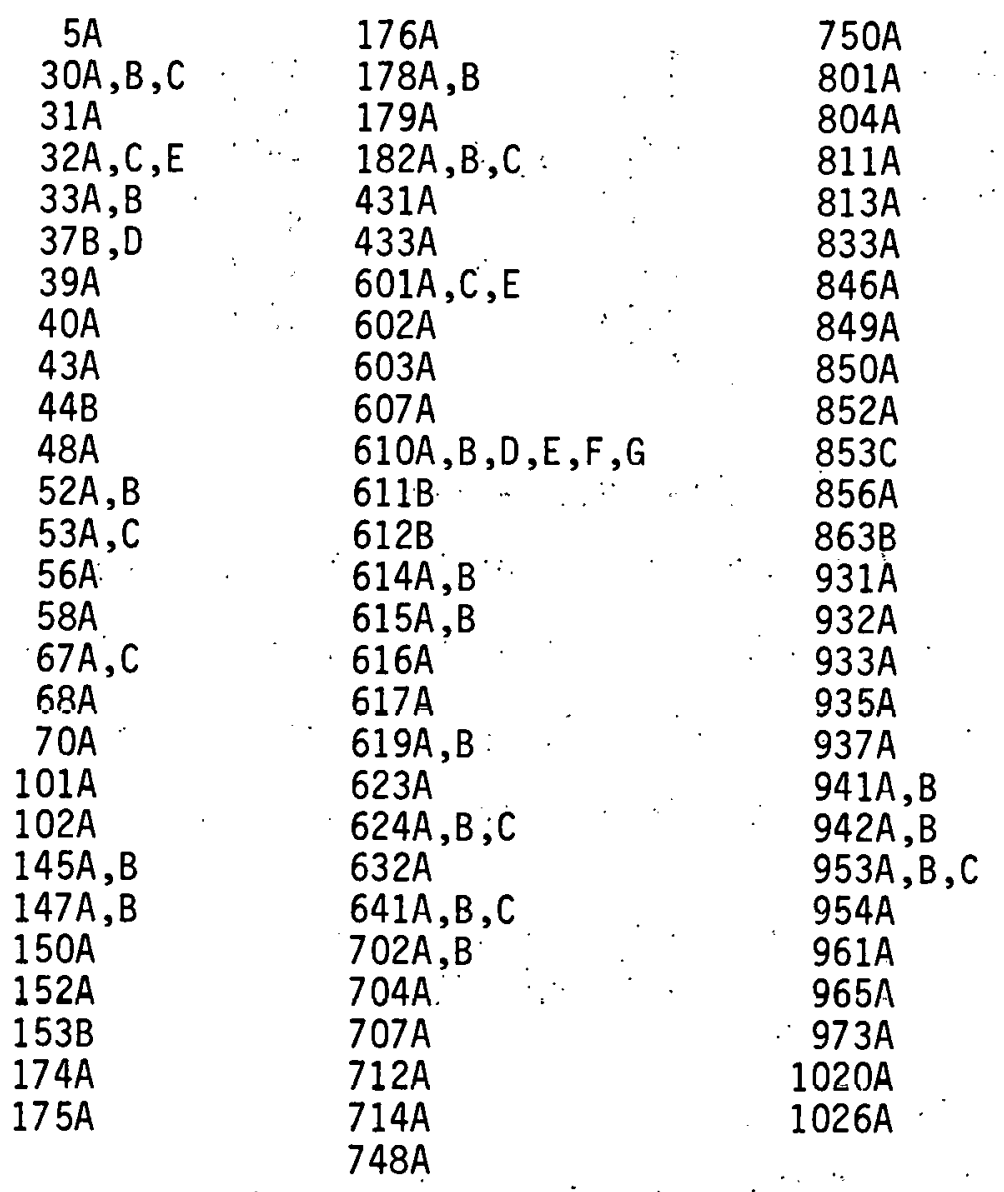

Condition 3--Partially Standing Structures

Forty-six partially standing structures were recorded. The structures assigned to this category are listed below: 


$\begin{array}{llc}4 A & 55 A, B, C & 610 C \\ 15 A & 57 B & 632 B \\ 24 A & 62 A & 642 A, B \\ 32 D, F & 64 A & 762 A \\ 37 C, E & 67 B & 802 A \\ 38 C, D & 143 A, B & 820 C \\ 39 B & 151 A, B & 853 B \\ 44 A & 173 A & 859 A, B \\ 45 A, B & 177 A & 863 A \\ 53 B & 178 C & 939 A \\ 54 A, B & 601 B, D & 1016 A \\ & 609 A & \end{array}$

Condition 4--Standing Structures

Forty-one structures were classified as Condition 4; these are listed below:

$$
\begin{aligned}
& 16 A, B, C \\
& 32 B \\
& 37 A \\
& 38 A, B, E, F \\
& 39 C \\
& 57 A \\
& 62 B
\end{aligned}
$$

$151 C, D$
$153 A$
$409 A, B, C, D$
$413 A, B, C$
$415 A$
$454 A, B, C, D$
$611 A$
$612 A$

$612 A$

$613 A$
$622 A$
$640 A$
$643 A, B$
$763 A$
$820 A, B$
$853 A$

Structure Descriptions

Additional information on each of the structures recorded, including location and function, is given in Appendix B. Future research will investigate the traditional building practices of the Oak Ridge area in greater detail than is contained in the present report.

\section{Geographical Distribution of} Extant Structures

Condition 2-- Foundation Only

The locations of the structures listed in the previous section are shown in Figure 5. 


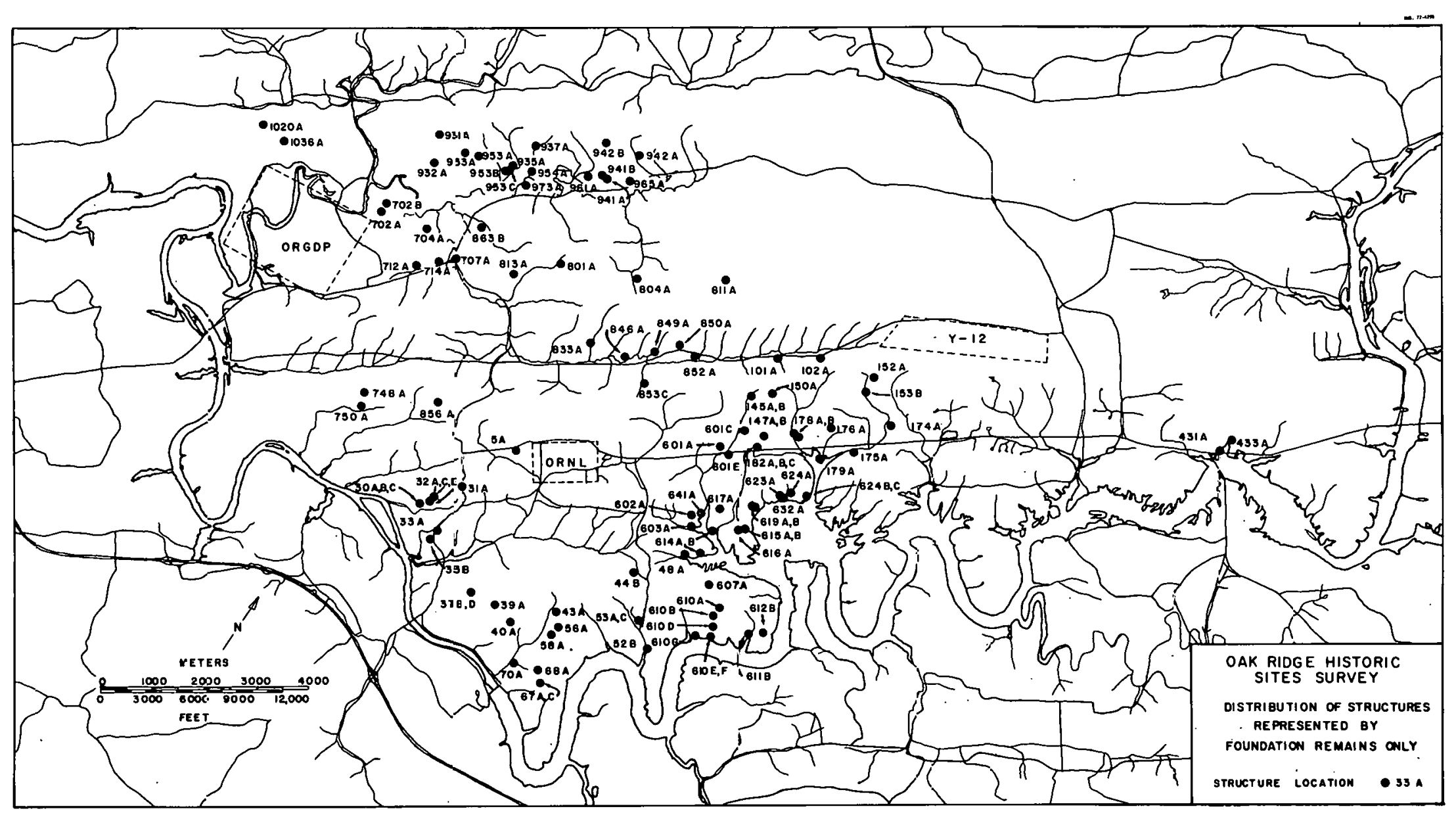

Fig. 5. Distribution of Structures Assigned to Condition 2--Foundation Only Extant Evidence. 
Condition 3--Partially Standing Structures

The location of Condition 3 structures is shown in Figure 6 .

Condition 4--Standing Structures

The location of Condition 4 structures is shown in Figure 7. 


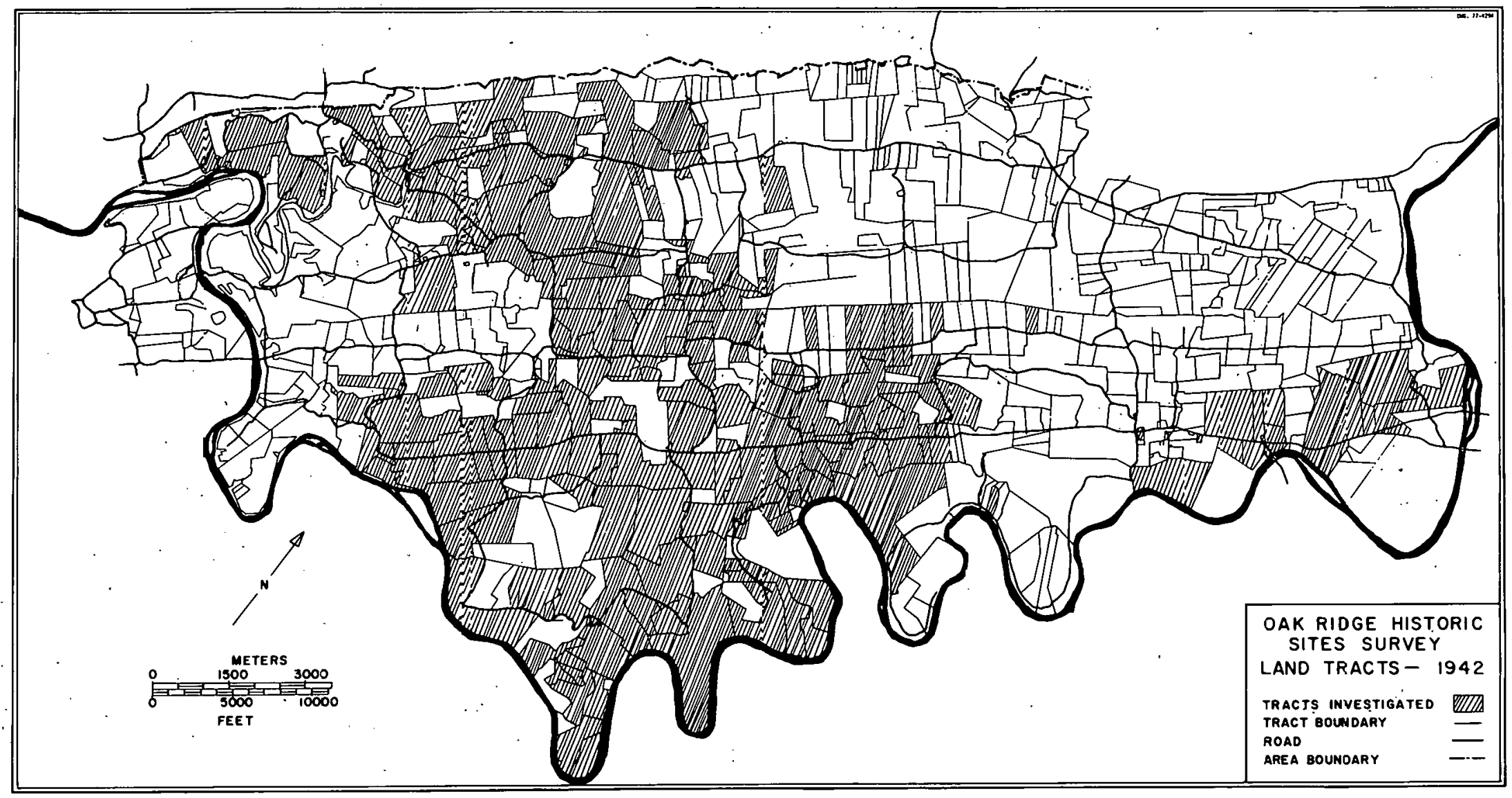

Fig. 6. Distribution of Structures Assigned to Condition 3--Partially Standing Structures. 


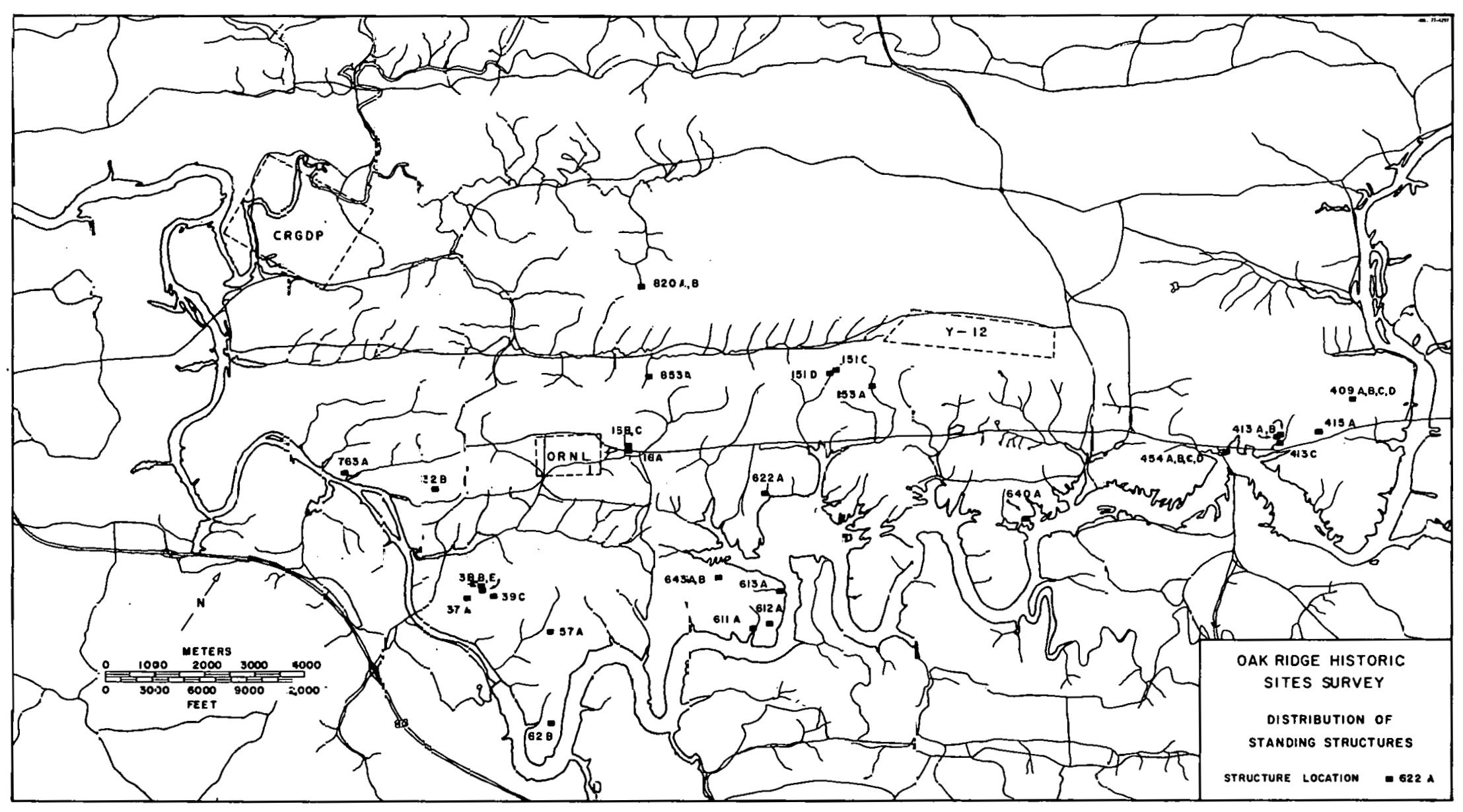

Fig. 7. Distribution of Structures Assigned to Condition 4--Standing Structures. 


\section{DISCUSSION OF RESULTS}

One of the striking results of the survey is that only about 20 percent of the sites examined contained standing or partially standing structures. There are several reasons for this situation. (1) Structures were probably partially razed by the former residents at the time of Federal acquisition. (2) Many structures were razed as a consequence of the construction of the Manhattan Project facilities. (3) During the 1950 's, standing structures on the reservation were made available for salvage of the usable building materials. This especially affected those structures located near ma in access roads.

The result of this selective deterioration of structural remains is that most of the present intact structures are located in the more isolated portions of the reservation. In one case, however, a situation developed in which several structures under the administration of the UT-CARL facility were preserved. Freels Cabin (Structure 640A), an excellent example of early nineteenth century log architecture, was preserved through adaptive restoration. This cabin, the focal point of an employee picnic area within the UT-CARL area, was maintained without significant alteration to the original fabric. It is presently in excellent condition and should be nominated for inclusion on the National Register of Historic Places (see Fielder 1974:29 for a description of the Freels Cabin).

Other wel1-preserved structures within the reservation include several houses that were moved from their original location in the Scarboro community. These houses are presently being used as housing for UT-CARL personnel. One other house in this group, Structure 426A, presently 
occupied by Mr. Merle Byrd, is in its original location and was apparently built around the middle of the nineteenth century. 
RECOMMENDED DISPOSITION OF RECORDED STRUCTURES

\section{Recommendation Categories}

The field recording form lists five possible field recommendations:

1. No further work required.

2. Salvage material from site.

3. Salvage structure, i.e. relocate if necessary to preserve structure.

4. Preserve structure in original location if possible.

5. Archaeological investigation necessary to reveal additional details.

Each of these fieid recommendations is briefly discussed below.

Category 1--No Further Work Required

This category is recommended in cases where the structure site or structure does not warrant mitigation of possible adverse impact, nor does it warrant further investigation based on available information.

\section{Category 2--Salvage Material from Site}

This recommendation is made when, in the judgment of the field recorder, the fabric of the structure does not warrant mitigation of impact in itself but does contain building materials that could be used advantageously in other restoration or reconstruction endeavors. For example, a structure that contained only several intact hewn oak logs and the dressed limestone foundation blocks for the chimney may not warrant preservation as a structure, but the logs and cut stone could be used in restoring another cabin. This field recommendation indicates that there are salvageable materials present on the site and that no other mitigation procedures are warranted. 


\section{Category 3--Salvage Structure}

This recommendation indicates that the fabric of the building is sufficiently complete and its architectural merits warrant mitigation of adverse impact through possible relocation of the structure. In this case, the inherent value of the building is in the architectural components rather than the immediate environs of the structure. This recommendation is only made when it is impossible to preserve the structure in its original location. It should be noted that once a structure is moved from its original location, it loses much of its value except in certain circumstances. For example, if the structure will be placed in a hostile environment (one which is out of character with the structure) due to surrounding development, then moving the structure to a more suitable location is desirable.

Category 4--Preserve Structure in the Original Location

This recommendation is preferred whenever possible, since it preserves the fabric of the structure as well as its natural surroundings. If it is not possible to preserve the structure in its original condition and/or on the original site, then the structure can be relocated to more suitable surroundings (Recommendation 3) or other mitigation of adverse impact. For structures satisfying the criteria for inclusion in the National Register of Historic Places, preservation on the original location is the only acceptable alternative, except in unusual circumstances.

Category 5--Archaeological Research Required

This category is applicable in the event a structure is historically significant and below-surface remains are the only ones 
present. None of the structures recorded by the survey fall into this category.

\section{Field Recommendations}

Field recommendations for the located structures were made by Messrs. Ahler and Barrington and are grouped by combinations of structure condition and recommendation. No additional research was recommended for 122 structures or structural remains.

Sixty-one structures contained salvageable materials such as timbers, hewn logs, weathered lumber, hand-split shakes, brick, and dressed limestone block. If the materials are made available to qualified groups to be used for restoration projects, the structural remains should be recorded (photographed, mapped, drawn) prior to salvage.

Seven structures were judged to have architectural merits that would warrant mitigation of adverse impact through relocation to more suitable surroundings. One place of relocation could be the University of Tennessee Arboretum, which is located on the eastern end of the reservation. A brief description of these seven structures is given on page 28.

Nine structures are recommended for on-site preservation through stabilization, restorition, and maintenance. These are described on page 31 .

Condition 2--Foundation Only Recommendation 1--No Further Work Required

A total of 83 structures (listed below) are included in this combination. Descriptions of each structure are given in Appendix $A$. 


$\begin{array}{clr}5 A & 152 A & 704 A \\ 30 B & 153 B & 706 A \\ 31 B & 174 A & 712 A \\ 32 C & 178 A & 714 A \\ 33 B & 179 A & 748 A \\ 37 B, D & 182 A, B, C & 750 A \\ 39 A & 431 A & 801 A \\ 40 A & 433 A & 804 A \\ 43 A & 601 A, C, E & 833 A \\ 44 B & 602 A & 850 A \\ 48 A & 603 A & 852 A \\ 53 A, C & 607 A & 853 C \\ 56 A & 610 A, B, D, E, F, G & 856 A \\ 58 A & 611 B & 931 A \\ 67 A, C & 612 B & 932 A \\ 68 A & 614 A, B & 935 A \\ 70 A & 615 A, B & 937 A \\ 101 A & 617 A & 941 A \\ 102 A & 619 A & 953 C \\ 145 A, B & 624 C & 965 A \\ 147 B & 632 A & 973 A \\ 150 A & 641 A, B, C & 1036 A\end{array}$

Condition 2--Foundation Only Recommendation 2--SaTvage Structure Materials

Thirty-one structures (listed below) were recorded as foundation onty and salvageable material present on the site. The salvageable material primartly consists of cut limestone and brick chimney and fireplace materials. Detailed descriptions of each structure are given in Appendix B. The location of these structures is shown in Figure 5 .

$\begin{array}{clc}30 A, C & 616 A & 863 B \\ 32 A, E & 619 B & 933 A \\ 33 A & 623 A & 941 B \\ 52 B & 624 A, B & 942 A, B \\ 147 A & 702 A, B & 953 A, B \\ 175 A & 811 A & 954 A \\ 176 A & 813 A & 961 A \\ 178 B & 846 A & 1020 A \\ & 849 A & .\end{array}$

Condition 3--Partially Standing Structure Recommendation 1--No. Further Work Required

Twelve structures were recorded under Condition 3 and Recommendation 1. All of these structures are either recent (ca. 1930-40) or 
have deteriorated to such a degree that no salvageable materials are present. These structures are listed below; a detailed description of each structure is given in Appendix $A$. The location of these structures is shown in Figure 6.

$\begin{array}{lll}37 C & 62 A & 601 B \\ 45 B & 67 B & 632 B \\ 53 B & 143 A, B & 820 C \\ 55 C & 178 C & \end{array}$

Condition 3--Partially Standing Structure Recommendation 2--Salvageable Material Present

Twenty-seven structures were included in this combination of condition and recommendation; the locations of these structures is shown in Figure 6. A description of each of the structures is given in Appendix A.

$\begin{array}{crr}4 A & 54 A & 642 B \\ 15 A & 64 A & 762 A \\ 24 A & 151 A & 802 A \\ 32 D, F & 173 A & 853 B \\ 37 E & 177 A & 859 A, B \\ 38 C, D & 601 D & 863 A \\ 39 B & 609 A & 939 A \\ 44 A & 610 C & 1016 A\end{array}$

Condition 3--Partially Standing Structure Recommendation 3--salvage Structure

Four structures, 55A, 55B, 57B, and 151B, were assigned to this combination. The location of these structures is shown in Figure 6 . A detailed description of the structures is given in Appendix $A$.

Condition 3--Partially Standing Structure Recommendation 4--Preserve Structure

One structure, 853B, was recommended by the field party in this combination. The senior author, however, places this structure in Recommendation 3. This structure, a log crib, does not necessarily warrant preservation in situ in the absence of other farmstead buildings. 
Condition 4--Standing Structure (Fig. 7) Recommendation 1--No Further Work Required

The field party assigned 12 structures to this combination: 409A, B, C, D; 413A, B, C; 415A; and 454A, B, C, D. Structures 409A, B,C,D; 413A, B, C; and 415A are presently occupied by UT-CARL personnel, thus providing a measure of preservation through adaptive use. From the results of this reconnaissance, it does not appear that any of the above structures requires any special consideration other than present use. Structures 454A, B, C, D are presently unoccupied. Based on the reconnaissance data, the structures can probably be razed without adverse impact on the cultural resources of the reservation. However, they should be examined in detail prior to actual demolition.

Seven structures (38E; 151C, D; 611A; 612A; and 820A, B) were recommended by the field party for in situ preservation. However, the senior author recommends that these structures be left in their present condition and location, but that they do not warrant further mitigation of adverse impact other than photographing and preparing measured drawings prior to razing.

Structure $38 \mathrm{E}$ is a pole-construction tobacco barn in good condition. Structure $151 \mathrm{C}$ is a frame outbuilding with vertical board wall covering and a gable roof. Structure 1510 is a frame henhouse with vertical board walls and a shed-type roof. Structure $611 \mathrm{~A}$ is a small frame house with a central brick chimney. Exterior wall covering is vertical board and batten. Structure $612 \mathrm{~A}$ is a small frame house in good condition. Structure $820 \mathrm{~A}$ is a frame henhouse with a shed-type roof. Structure $820 B$ is a frame shed with gable roof. 
Combination 4--Standing Structure (Fig. 7) Recommendation 2--Salvage Materials Present

Four structures $(37 \mathrm{~A}, 613 \mathrm{~A}, 622 \mathrm{~A}, 643 \mathrm{~A})$ were assigned to this combination.

Structure $37 \mathrm{~A}$ is a frame house presently in a poor state of repair; the roof has partially collapsed and portions of the wal1 have fallen. Salvageable material present includes weathered boards, split shakes, and brick.

Structure 613A, a two-story frame house, contains salvageable material including two complete brick chimneys and fireplaces, splitshake roofing, and weatherboard siding.

Structure 622A, apparently used as a henhouse, is a frame building with horizontal and vertical board siding and a split-shake roof. Salvageable material includes split shakes and weathered lumber.

Structure 643A, a small one-story house, is of frame construction with board-and-batten walls. Salvageable materials present in this building include weathered lumber and split-shake roofing.

Condition 4--Standing Structure (Fig. 7) Recommendation 3--Salvage Structure

Three structures (32B, 62B, 643B) were judged of sufficient merit to warrant possible relocation to better protected and maintained surroundings.

Structure $32 B$ is a log crib constructed from partially hewn pine logs (Fig. 8). It is typical of the small cribs found on many farmsteads in eastern Tennessee.

Structure 62B, a log crib without a roof, is in acceptable condition to relocate. This structure would require some restoration, however, before it could be used as a functional building (Fig. 9). 


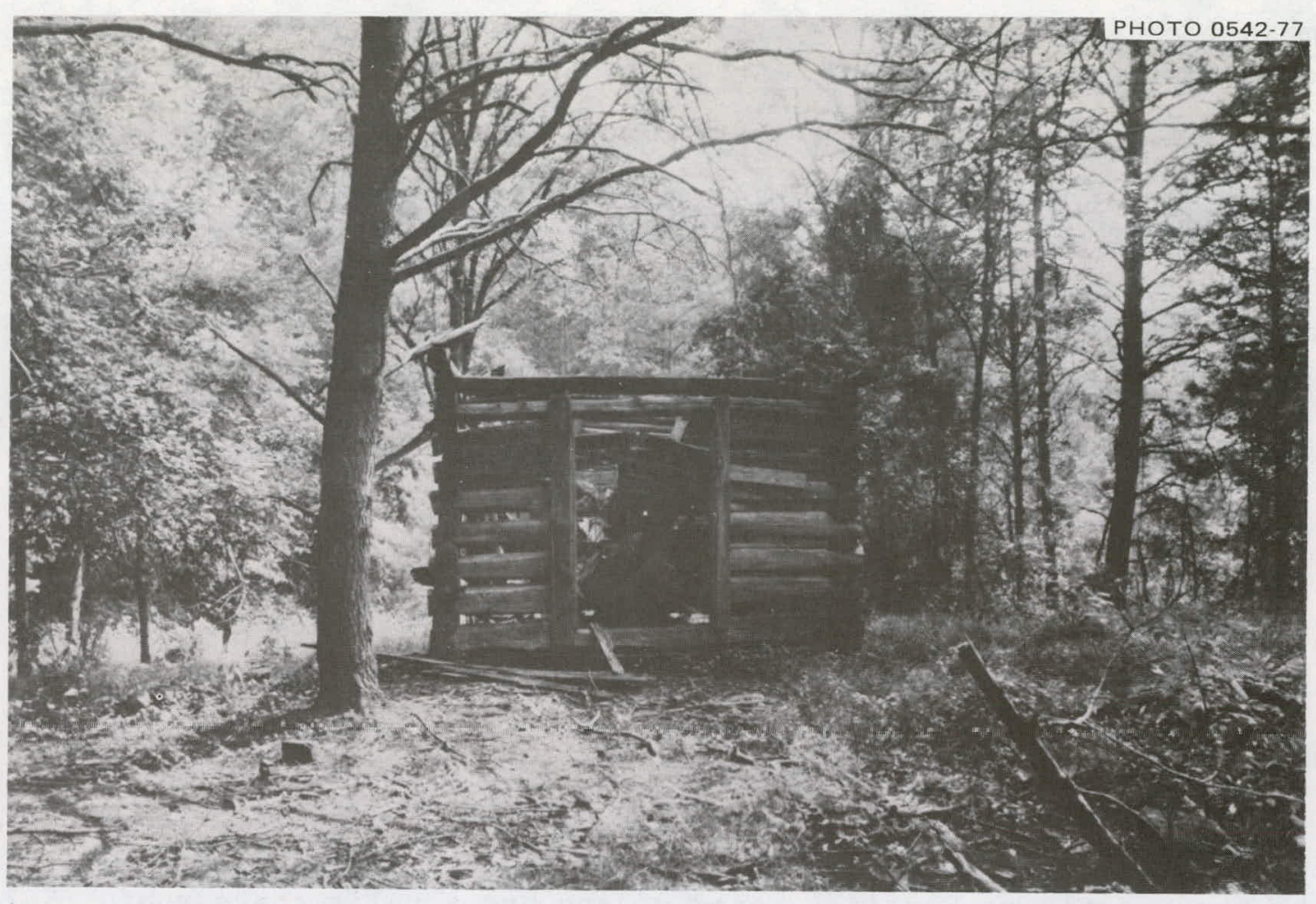

Fig. 8. Front Elevation of Structure 32B, a Log Crib.

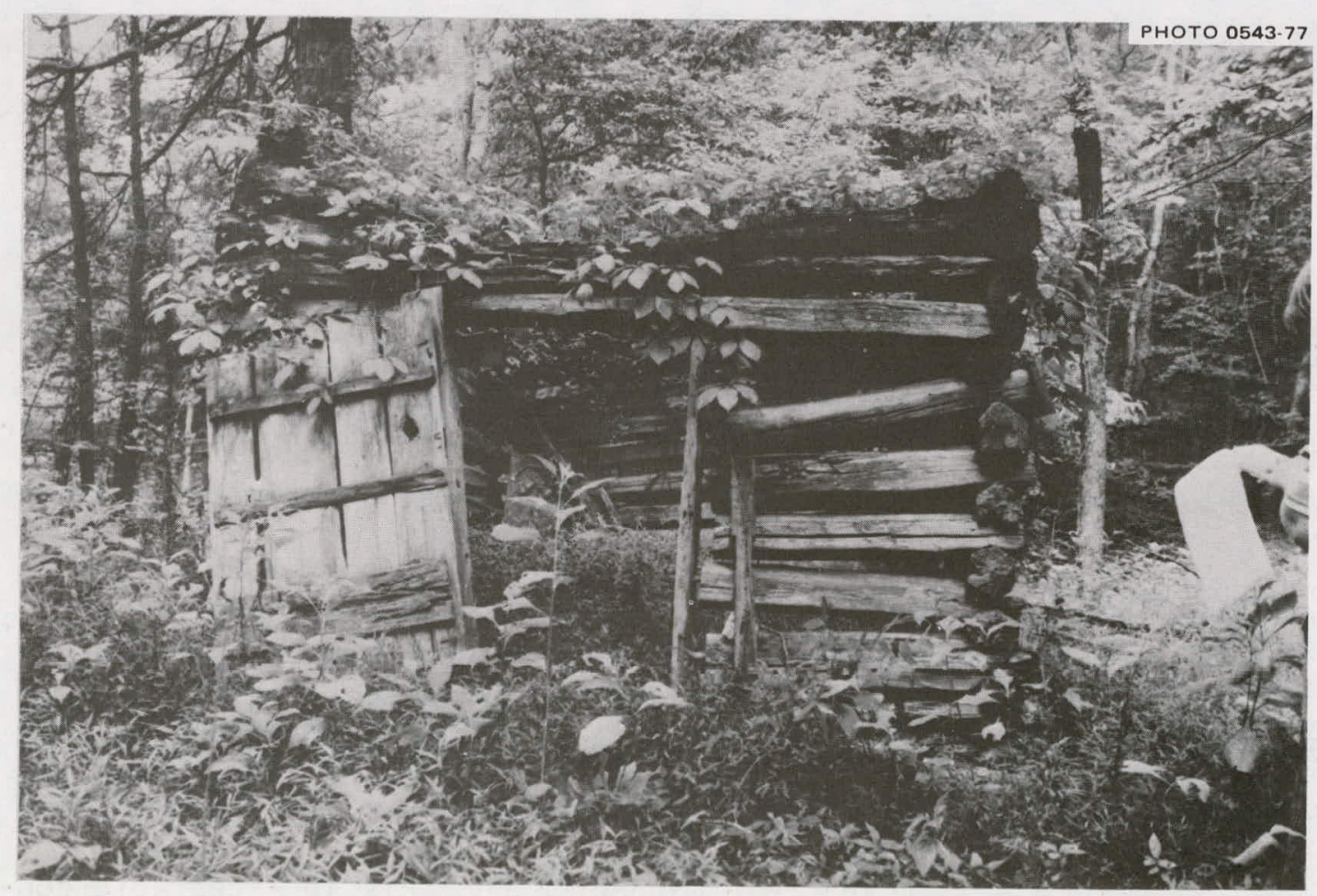

Fig. 9. Front Elevation of Structure 62B, a Log Crib with V-Notched Logs. 
Structure 643B is a good example of a round-log-constructed crib. The walls and roof are intact (Fig. 10).

Condition 4--Standing Structure Recommendation 4--Preserve Structure in Original Location

Nine structures, described below, should be preserved by maintaining them in their present condition and location. Should these structures be threatened by adverse impact of future construction or other destructive activities, mitigation of impact should be undertaken. Mitigation could include avoiding the structure areas, relocation to favorable environment, or detailed description of the fabric prior to unavoidable destruction.

Structure 16A. This structure, known as New Bethe1 Church, is located at the site of a mid-nineteenth century church. The present structure was apparently built in 1924, if the date inscribed in the steps is the construction date. The building is presently used by Oak Ridge National Laboratory for a nonreligious purpose. The structure does not appear architecturally distinctive enough to qualify for inclusion on the National Register, but it should be recorded in detail if future construction would require the building to be razed. The associated cemetery is presently in use by area residents and, since the church building plays an important role in the religious function of the cemetery, due consideration should be given from the cultural standpoint before the structure is razed.

Structures $16 \mathrm{~B}$ and $16 \mathrm{C}$. These two structures, quite unusual and very distinctive, are built over and enclosing marked graves in the New Bethel cemetery. The construction technique employed is frame with picket fence walls surrounding the grave (Fig. 11). 


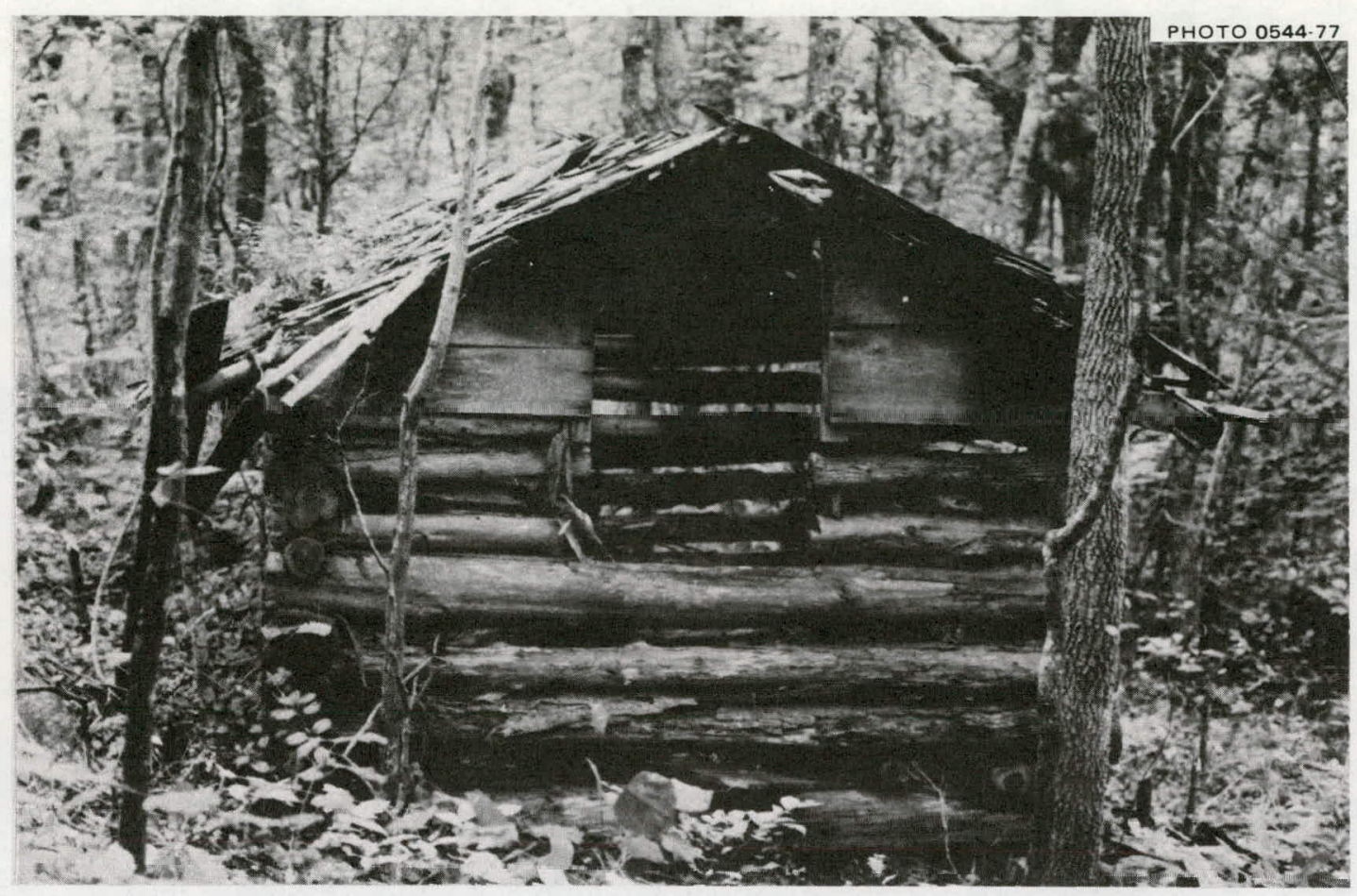

Fig. 10. Crib Constructed from Round Logs (Structure 643B).

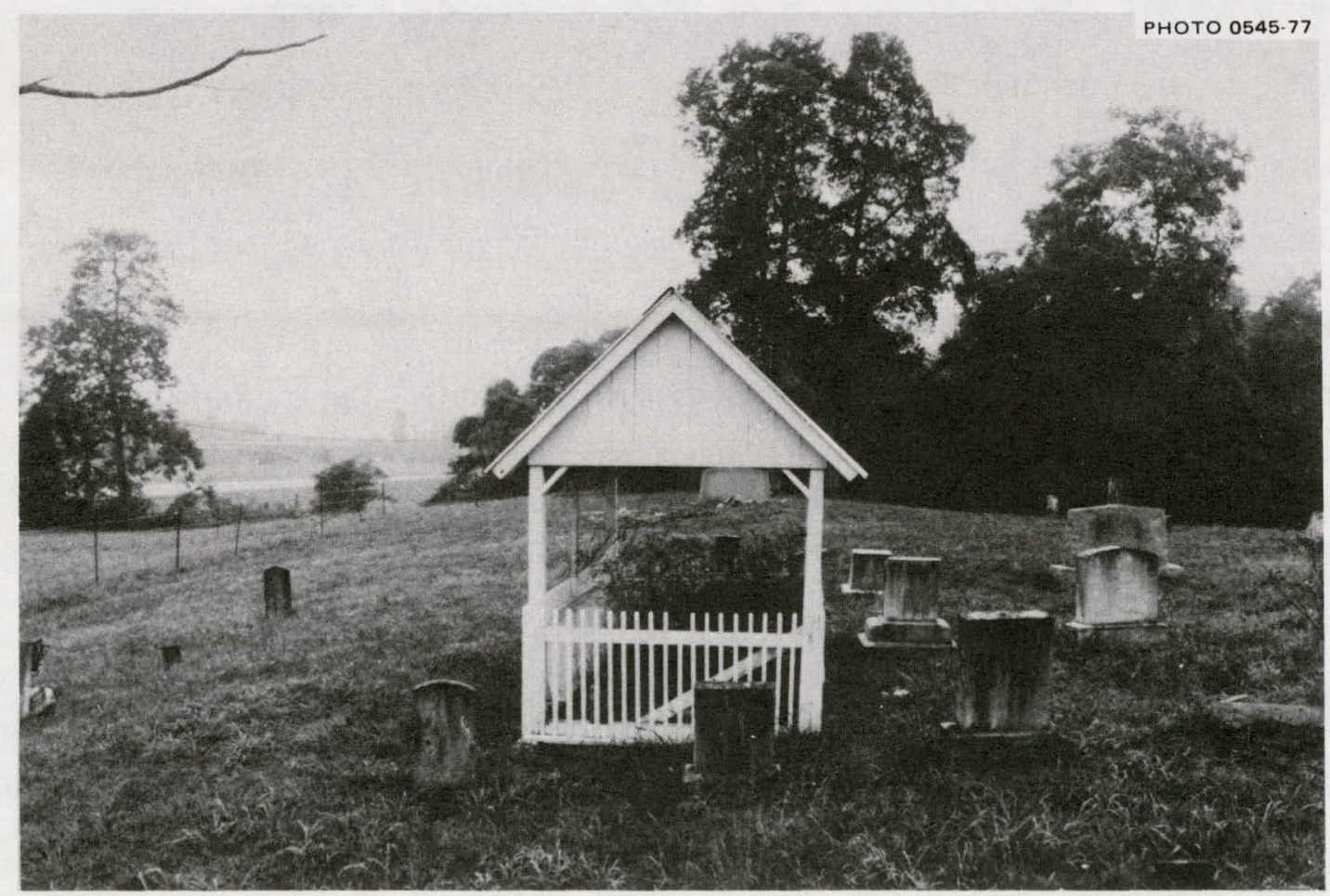

Fig. 11. Grave House in New Bethel Cemetery (Structure 16B). 
These two structures should be preserved in their present condition and maintained periodically. Their significance lies in their traditional form and as preserved examples of a kind of structure no longer found in contemporary cemeteries and memorial gardens.

Structure 38B. This structure apparently functioned as a smokehouse but was constructed airtight. Only the door has windows, and they do not open. The main part of the building is of horizontal log construction with square-notch corner timbering. The door is double thickness with cardboard between the boards. The walls are approximately 15 inches thick and solidly built. Although the building was probably built in the twentieth century, it is quite interesting from a constructionmethod standpoint. The senior author plans to try to locate former residents of the area who can provide more information concerning this structure.

It is recommended that this building be maintained in its present condition. If it is to be affected by some future construction or other adverse impact, the building should be recorded in detail, and possibly moved to less hostile surroundings. However, it does not meet the criteria for inclusion on the National Register.

Structure $39 \mathrm{C}$. This structure is a small one-crib log barn with shake roof in good condition (Fig. 12). Based on the log sizes, cornernotching technique, and general appearance, this building was probably built in the twentieth century. It does, however, represent a traditional form and construction method and should be preserved through maintenance and periodic monitoring the condition. Should the building be threatened by construction or other potentially destructive activities, it should be described in detail and possibly relocated to more favorable surroundings. 


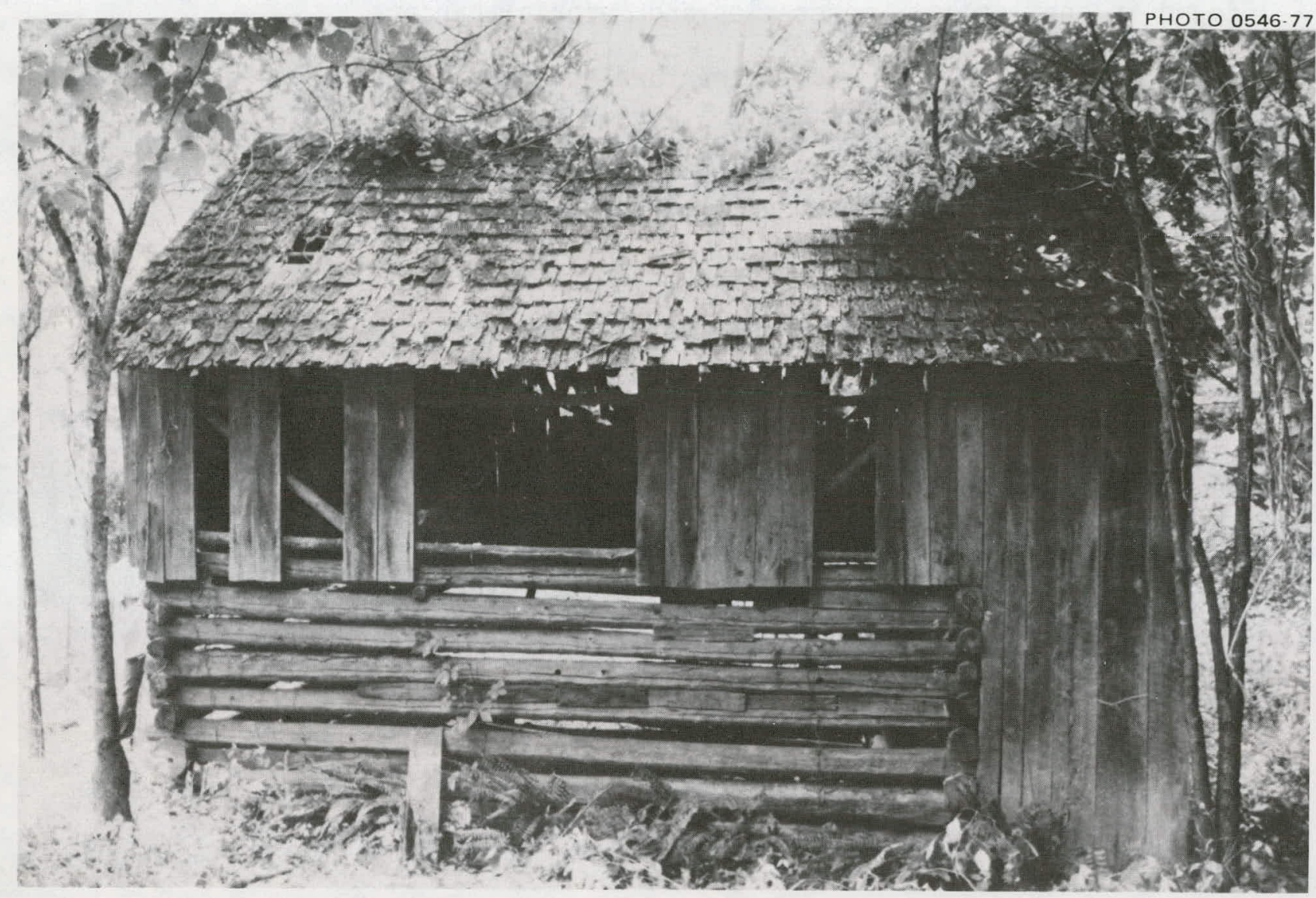

Fig. 12. Structure 39C, Single Crib Barn with Shake Roof. 
It does not appear to meet the criteria for nomination to the National Register.

Structure 57A. This structure is a rectangular-log-construction gravehouse built surrounding three grave markers. The fieldstone markers, two headstones and one footstone (two graves), are plain without any inscriptions. The gravehouse was constructed from partially hewn logs joined at the corners with a saddle V-notch (Figs. 13 and 14). It is in good condition and only the roof has collapsed. The cemetery associated with this structure is designated No. 14.

It is highly recommended that the structure be restored by replacing the roof and that it be maintained in a good state of repair as part of the routine cemetery maintenance. This unusual building warrants preservation due to the very small number of $\log$ gravehouses remaining in Tennessee.

Structure 153A. This structure is a good example of the style of $\log$ houses built in the 1930's and 1940's. Constructed of round small logs saddle notched at the corner, it is basically a double-pen house with an ell to the rear (Fig. 15). The building is presently posted as an ecological study area.

It is not necessary to maintain this structure in its present condition; however, it should not be razed. If it is to be razed in the future due to construction or other reasons, a set of detailed drawings and photographs should be prepared to record an example of twentiethcentury log construction.

Structure 753A. This was the only stone building encountered during the survey. Built using fieldstone bonded with cement mortar, it has a rectangular plan and a gabled roof (Fig. 16). The field party 


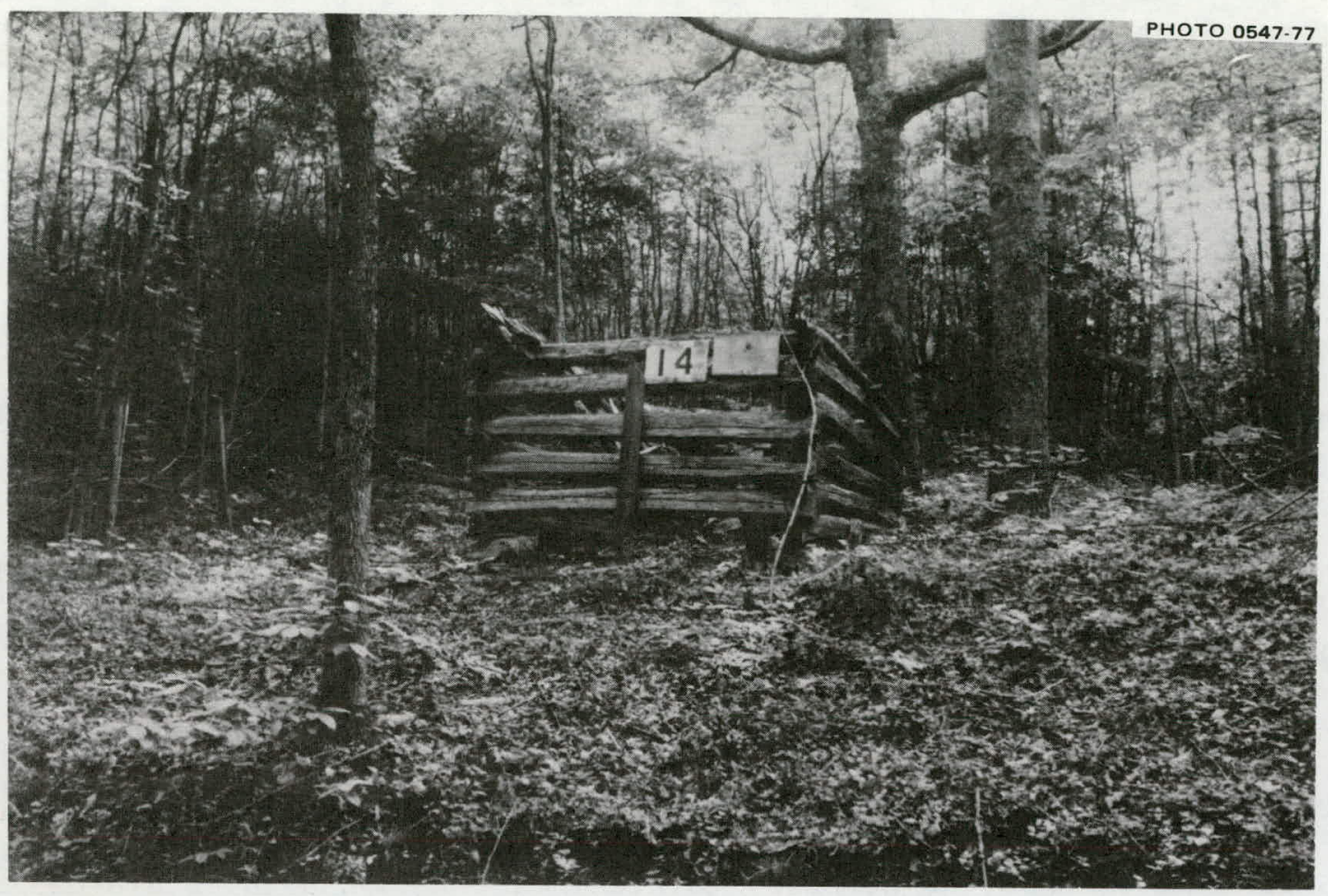

Fig. 13. Structure 57A, Log Construction Grave House Surrounding Two Graves.

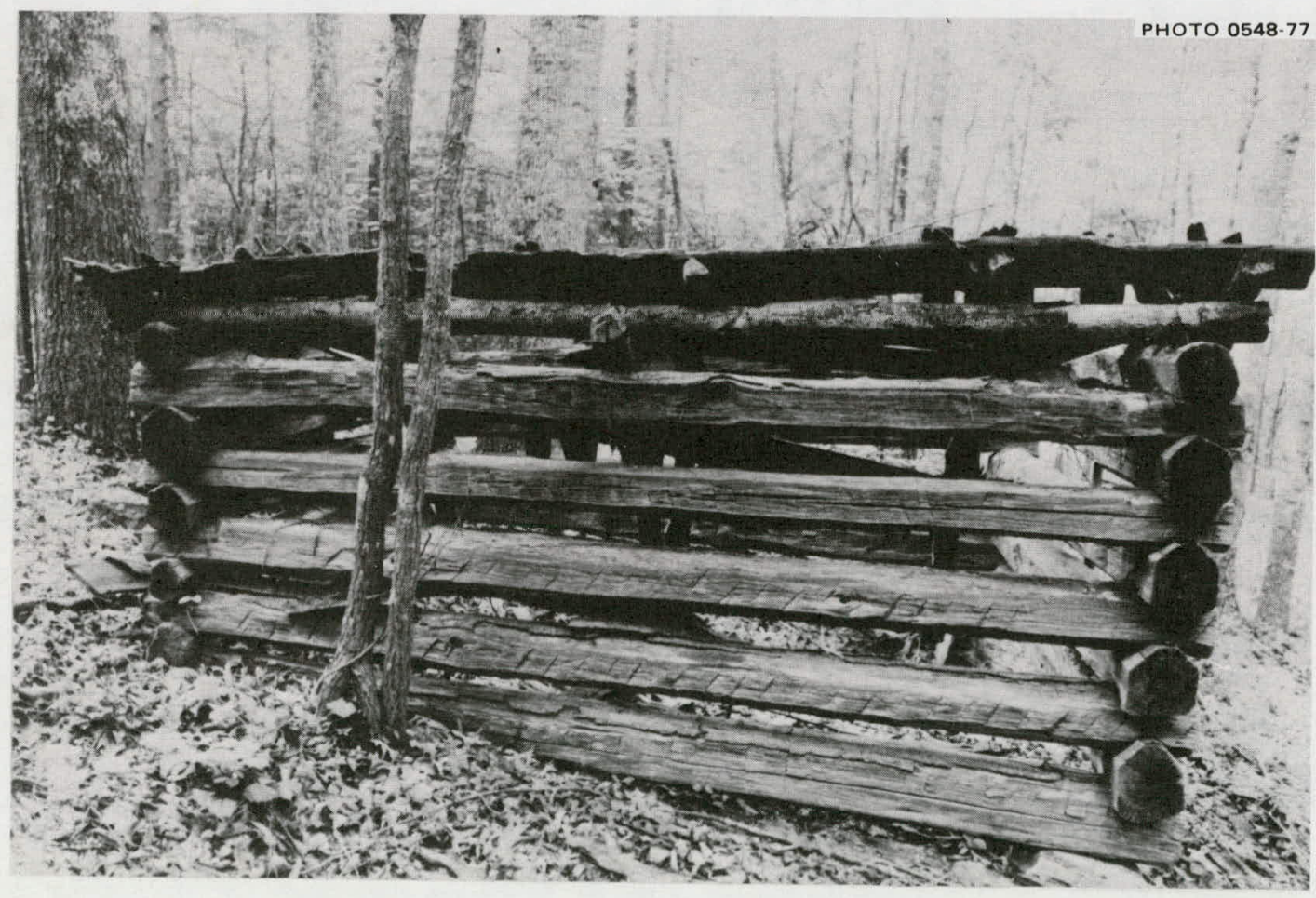

Fig. 14. Side View of Structure 57A. 


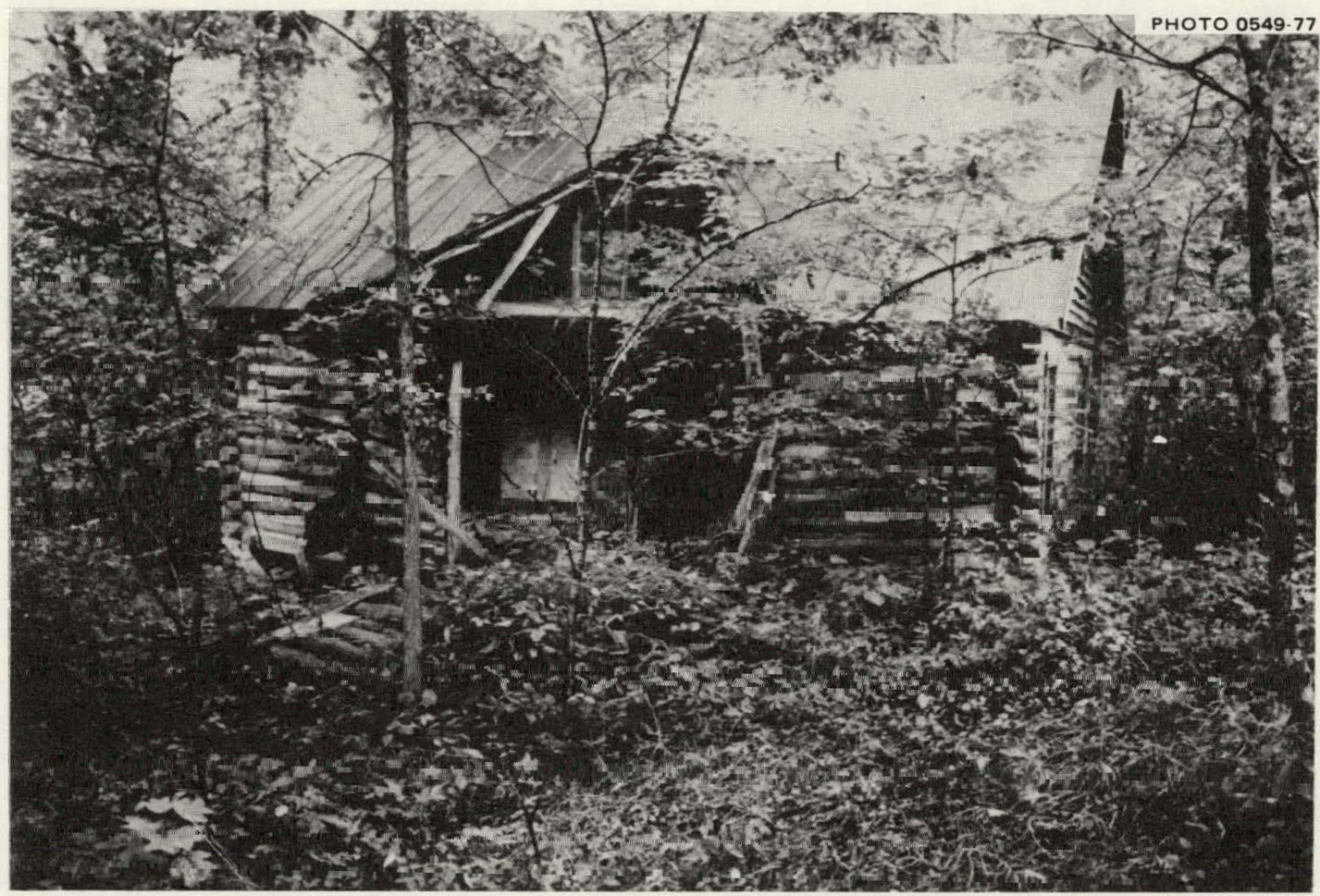

Fig. 15. Rear Elevation of Structure 153A, Round Log Constructed House.

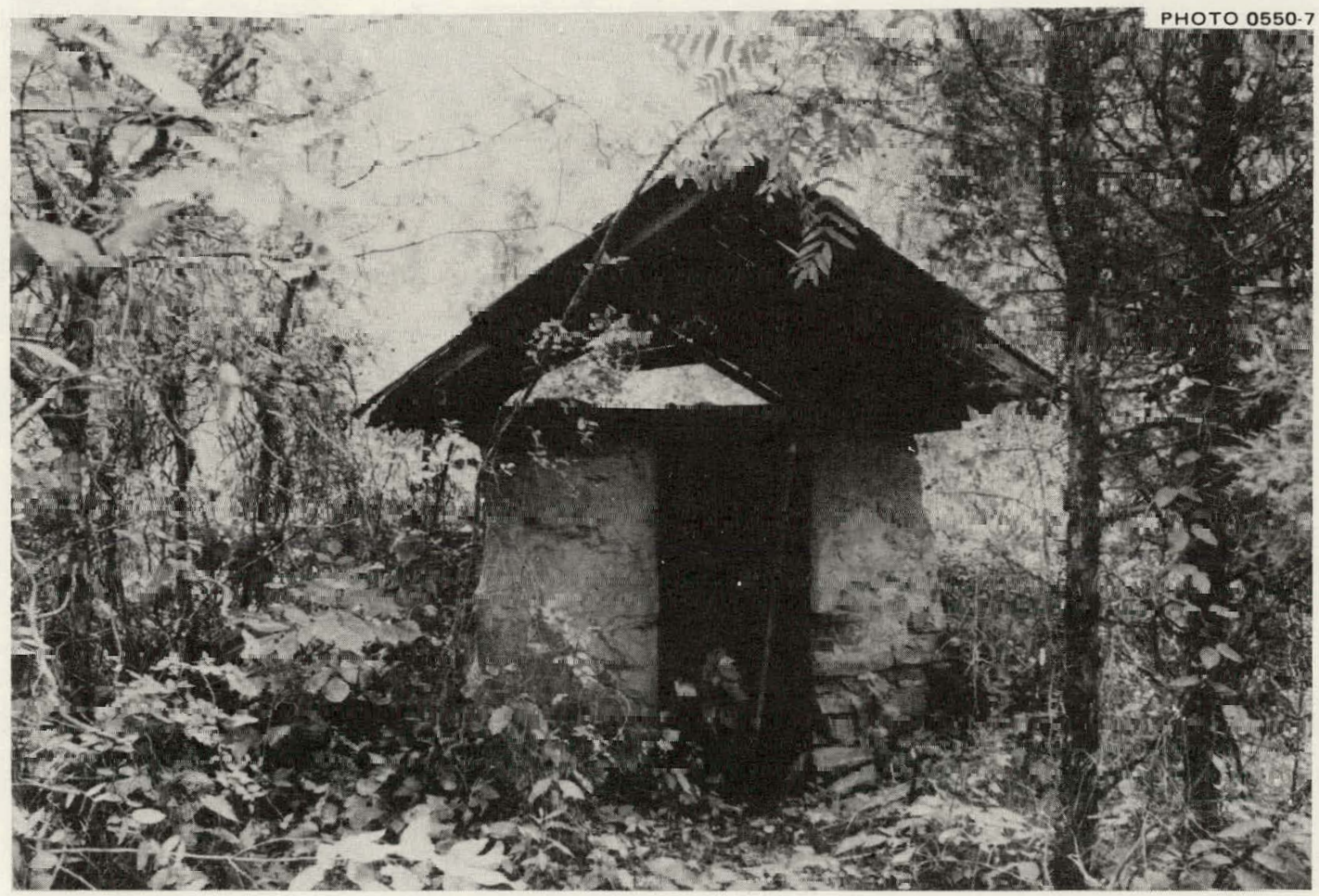

Fig. 16. Field Stone Construction Building, Structure 753A. 
did not determine the function of this structure. Measured drawings and detailed photographs should be prepared of this building if it is threatened with destruction.

Structure 853A. Excluding the Freels Cabin, the best example of $\log$ architecture recorded by the survey party is Structure $853 \mathrm{~A}$, a singlepen rectangular-plan house with one external limestone block chimney Figs. 17 and 18). The date of construction has not been determined from documentary sources; but based on the construction methods, size and location of windows, and type of chimney construction, it was possibly built in the first half of the nineteenth century. One end of the structure has been removed to accommodate a frame addition. The structure should be maintained in its present condition until historical research can establish a factual date of construction. 


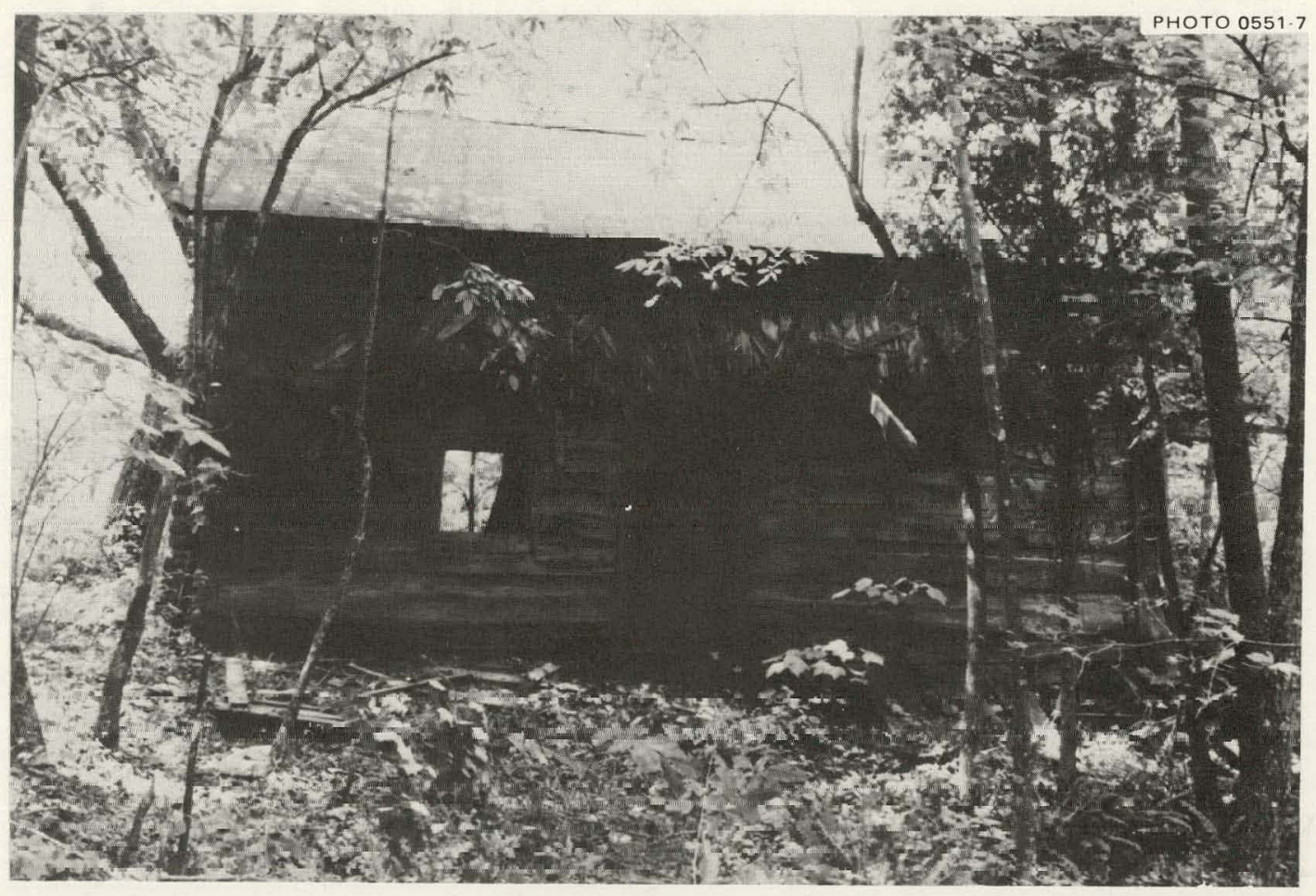

Fig. 17. Front Elevation, Structure 853A.

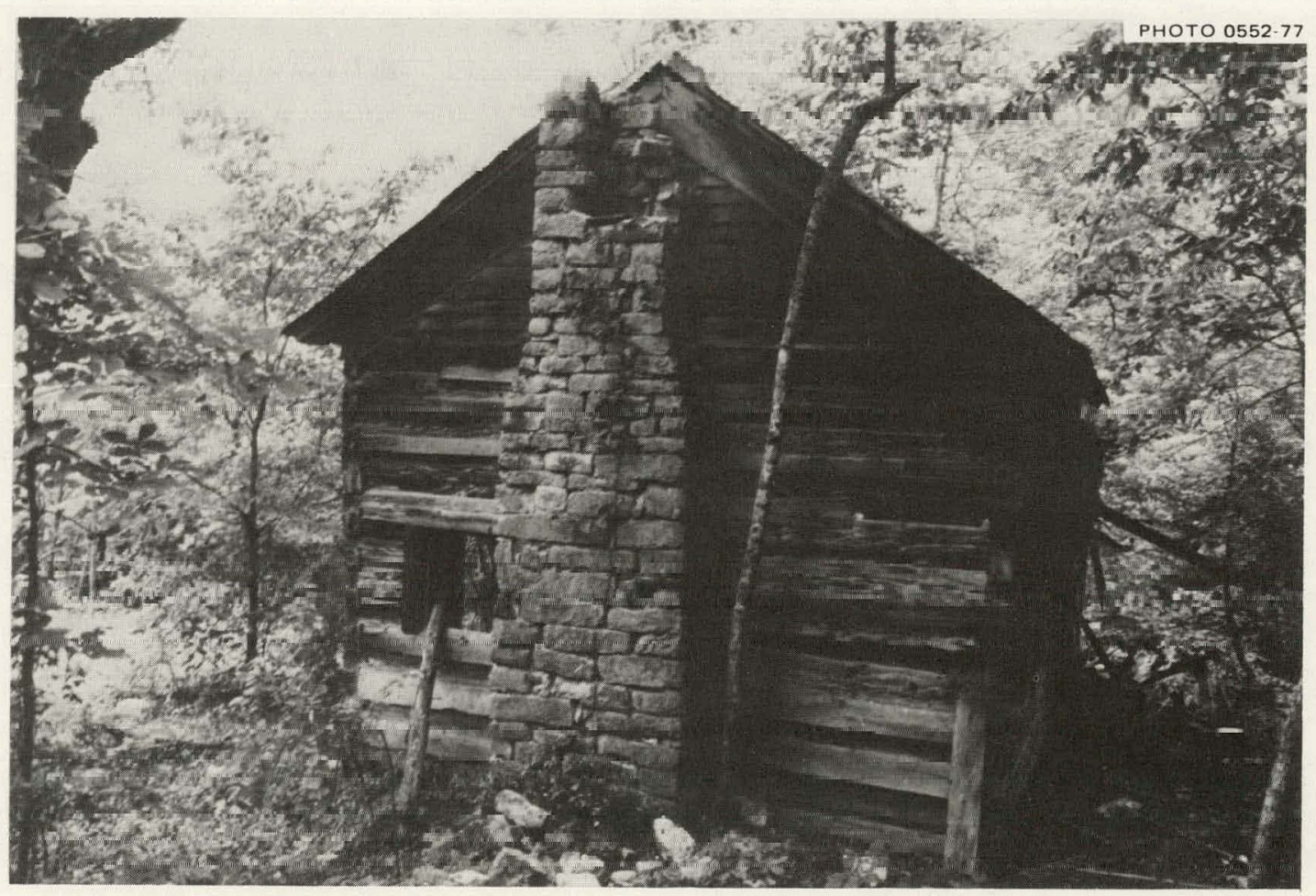

Fig. 18. Chimney Detail, Structure 853A. 


\section{CONCLUSIONS}

1. The reconnaissance obtained detailed information on historicperiod Euroamerican sites and structures within the Federally controlled Oak Ridge reservation.

2. Four hundred fifteen structures and/or structure locations were located, described, and evaluated with regard to their architectural and historical merits.

3. The reconnaissance determined that 215 structures have no physical evidence extant, 115 are only represented by foundations, 46 are partially standing, and 41 are standing structures.

4. Adaptive restoration, possible relocation, and on-site preservation through periodic monitoring and maintenance of selected structures are the preferred means of preserving the historical information represented by thesc examples of traditional architecture.

5. One structure, the Freels Cabin $(640 \mathrm{~A})$, an excellent example of early nineteenth century log architecture, should be nominated to the National Register of Historic Places.

6. The reconnaissance, although not a study in folk culture in itself, generated data that can be incorporated into local and regional syntheses of traditional cultural practices. 


\section{RECOMMENDATIONS}

1. The Freels Cabin (Structure 640A) should be nominated to the National Register of Historic Places. Located on lands administered by University of Tennessee Comparative Animal Research Laboratory (UT-CARL), the double-pen house is an excellent example of early nineteenth century log architecture (Fig. 19). The workmanship is of the highest caliber, and the floor plan (Fig. 20) is very similar to that of another early nineteenth century eastern Tennessee log house at Exchange Place, Kingsport. Exchange Place, built in 1820 , is a National Register property.

2. The structures currently used for housing UT-CARL personnel should be maintained in their present condition and use.

3. The date of construction of Structure $853 \mathrm{~A}$, a log house with limestone chimney, whould be determined through historical research. The type of construction and other structural details indicate the house was possibly built in the mid-nineteenth century or before.

4. Three gravehouses, Structures 16B, 16C, and 57A, are unusual cultural features and should be maintained in good repair in conjunction with periodic cemetery maintenance. Structure 57A, a log gravehouse, should have the roof repaired to insure against further structural deterioration.

5. The following structures should be considered for relocation and adaptive restoration or interpretive restoration. The preferred place of relocation and maintenance is at the University of Tennessee Arboretum, which is located on the eastern end of the Oak RIdge reservation. This area is typical of the setting of the 


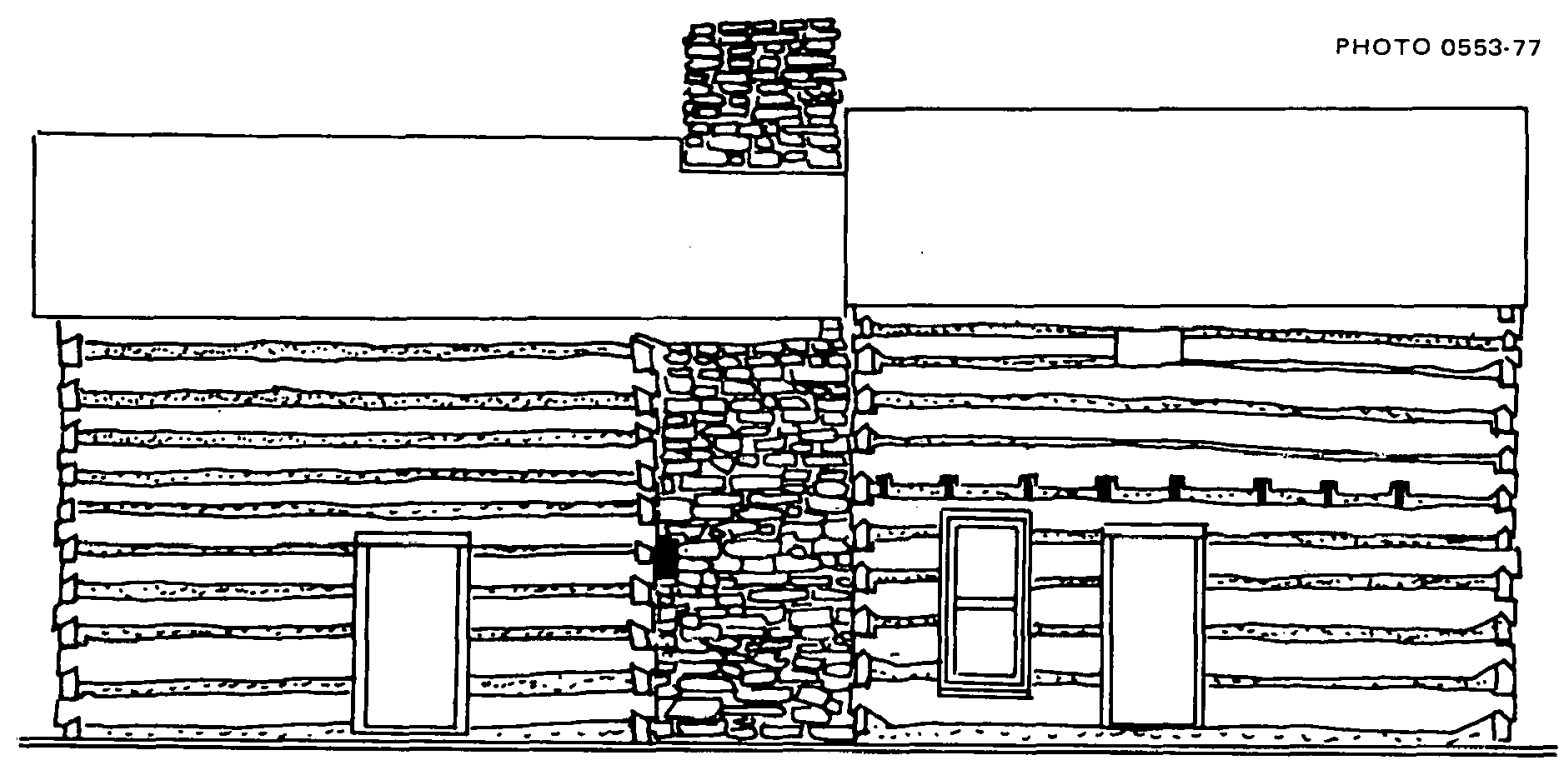

Fig. 19. North Elevation, Freels Cabin (Structure 640A).

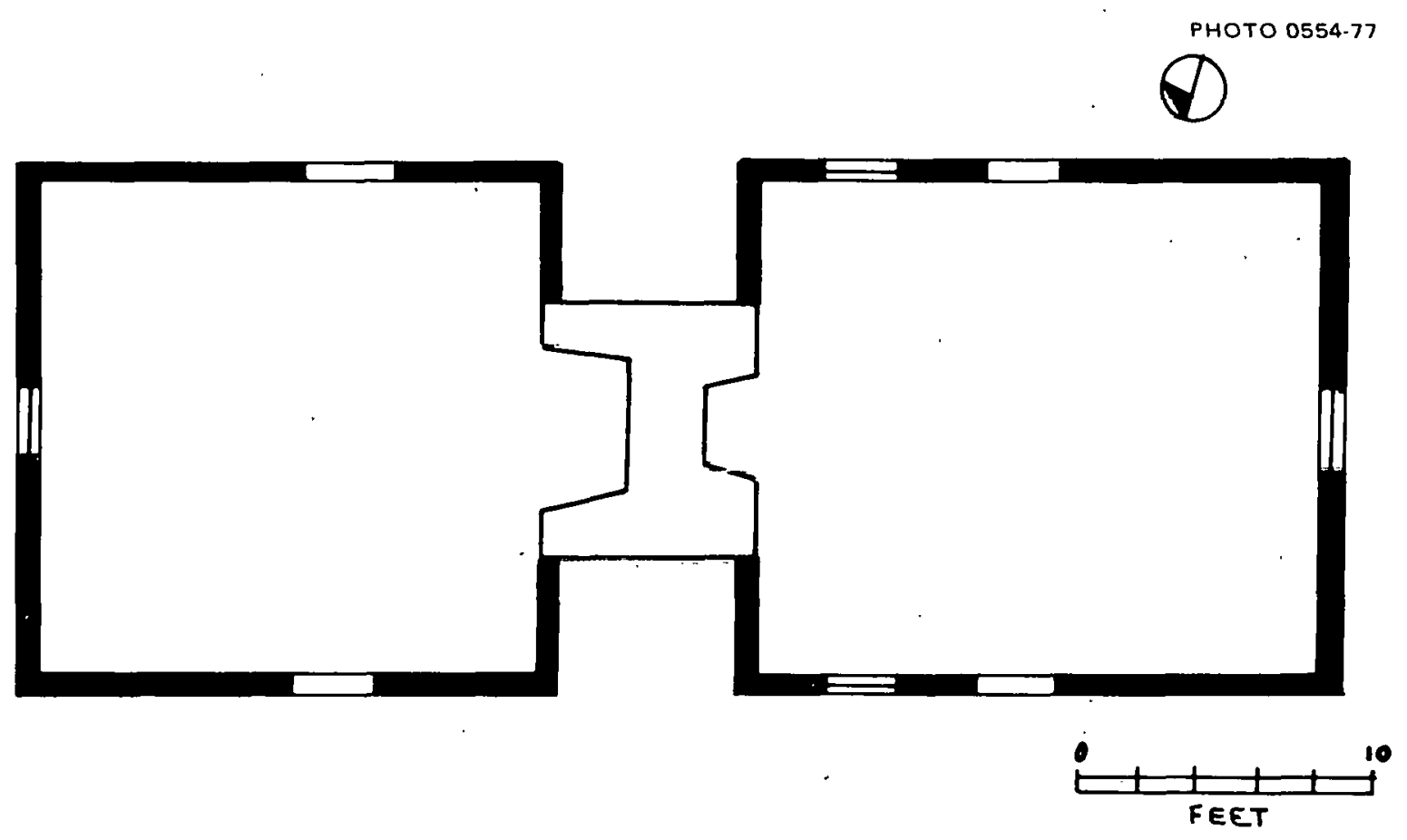

Fig. 20. Ground Floor Plan, Freels Cabin (Structure 640A). 
structures' original location and would provide for public access.

Houses: Structure 853A, a $\log$ house with limestone chimney (see Figs. 17 and 18).

Barn: Structure $39 \mathrm{C}$, a small single-crib log barn with splitshake roof (Fig. 12).

Crib: Structure $643 \mathrm{~B}$ is a rectangular crib constructed from round logs (see Fig. 10). Structure $32 B$ is a good example of a $\log$ crib with partially hewn logs (see Fig. 8). The restoration of this structure would require the installation of a shake roof.

6. Selected sites contain structural materials that could be used in other historic restoration and reconstruction projects. Should such projects be proposed and approved at any future date this material could be utilized if appropriate records are maintained. The recipient party should provide for the recording of structural information prior to removing the remains. This could be accomplished through the preparation of measured drawings and detailed photographic documentation of the existing condition of the remains before they are disturbed. Such information should be transmitted to the senior author or desginated person within ERDA. It would be added to the field records obtained by reconnaissance and substantially supplement the information concerning folk-building practices on the Oak Ridge reservation. 


\section{FURTHER RESEARCH}

The senior author plans to use the results of the present and prior research to prepare a research paper on the traditional architecture of the Oak Ridge area. In addition to the field data collected herein, interviews with former residents and historic photographic documentation of buildings made prior to Federal construction should be included. 


\section{REFERENCES CITED}

Fenneman, Nevin M.

1938 Physiography of the Easterm United States. New York:

McGraw Hi11.

Fielder, George F., Jr.

1974 Archaeological Survey with Emphasis on Prehistoric Sites of the Oak Ridge Reservation, Oak Ridge, Tennessee. ORNL-TM-4694, Oak Ridge National Laboratory, Oak Ridge, Tennessee.

1975a Cultural Resource Survey of the Exxon Nuclear Facility, Oak Ridge, Tennessee: An Interim Report. Department of Anthropology, University of Tennessee, Knoxville, Xeroxed.

1975b Evaluation of Archaeological and Historical Resources at the Proposed Expansion Area at ORGDP Site, Oak Ridge Reservation. Department of Anthropology, University of Tennessee, Knoxville. Xeroxed.

Roberts, Snyder

1969 The Roberts Families of Roane County, Tennessee 1794-1969.

Clinton, Tennessee: Creative Quill Publishing Company.

Robinson, George 0., Jr.

1950 The Oak Ridge Story. Kingsport, Tennessee: Southern Publishers, Inc.

Schroed1, Gerald F.

1972 Archaeological Reconnaissance and Test of Excavations in the Clinch River Liquid Metal Fast Breeder Reactor Plant Site Area. Report submitted to Tennessee Valley Authority by Department of Anthropology, University of Tennessee, Knoxville.

1974 Historic Sites Reconnaissance in the Clinch River Breeder Reactor Plant Area. Report submitted to Tennessee Valley Authority and Project Management Corporation by Department of Anthropology, University of Tennessee, Knoxville.

Seeber, Clifford

1928 A History of Anderson County, Tennessee. Unpublished Master's thesis, University of Tennessee, Knoxville.

Thomas, Prentice $M$.

1973 A Map of Two Historic Sites in the Clinch River Liquid Metal Fast Breeder Reactor Plant Area, Roane County, Tennessee. A report submitted to the Tennessee Valley Authority, Knoxville.

U.S. Tennessee Valley Authority

1942 Kingston Demolition Range Map.

U.S. War Department

1943-45 Final Ownership Maps. 


\section{APPENDIX A \\ INVENTORY OF RECORDED INVESTIGATED STRUCTURES}

This inventory is arranged numerically by acquisition tract number and structure number. Information concerning previous ownership and tract acreage is taken from U.S. War Department Final Land Acquisition Maps dated 1942-45. Structure location is given both in latitude and longitude and by reference to the appropriate Oak Ridge Administrative Grid Block determined from Oak Ridge Area Map S-16A (1974). Reconnaissance data on present condition and structure function is also presented.

Structure sites that were investigated but contained no physical evidence of the structure are not included in this inventory. 


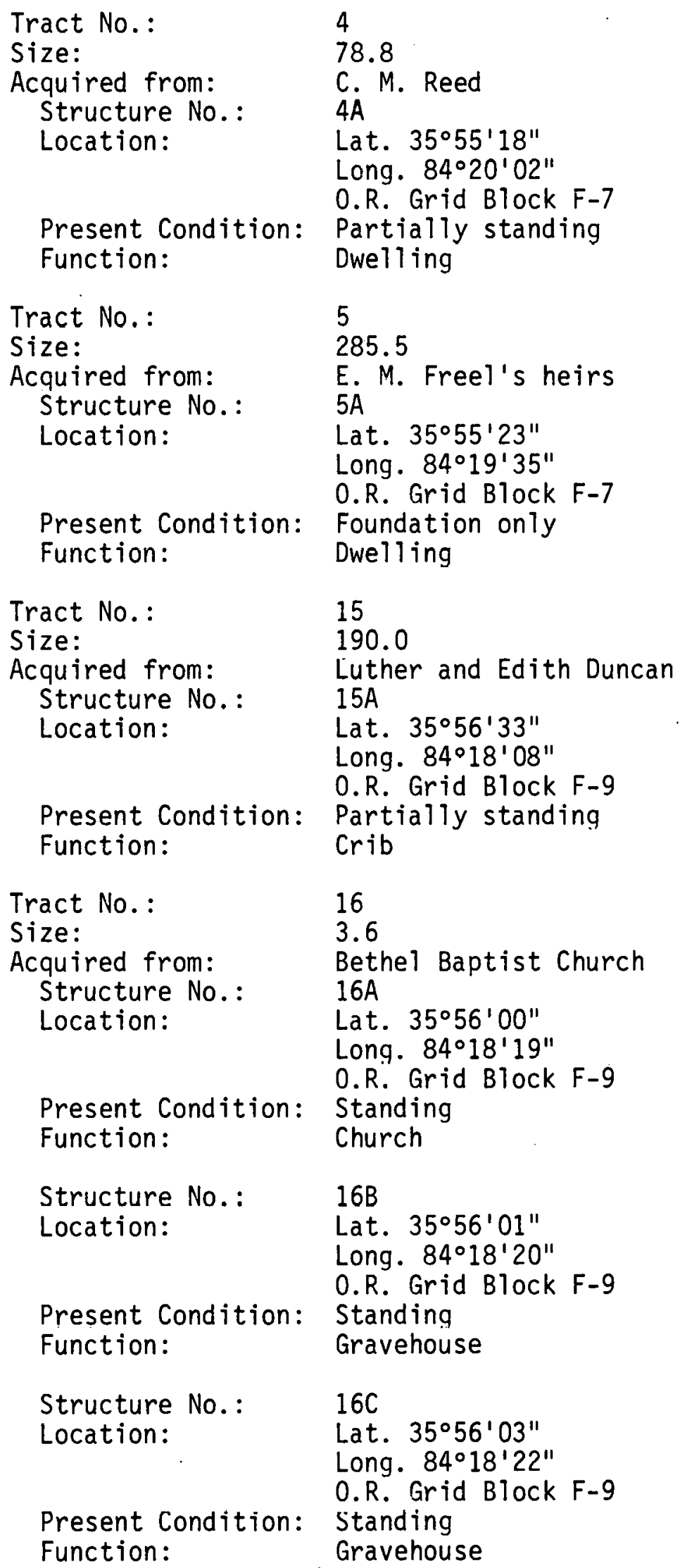


Tract No.:

Size:

Acquired from:

Structure No.:
Location:

24

264.2

A. L. Justice

24A

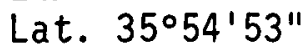

Long. $84^{\circ} 18^{\prime} 22^{\prime \prime}$

$0 . R$. Grid Block G-8

Present Condition: Partially standing

Function:

Dwelling

Structure No.: $\quad 24 B$

Location:

Lat. $35^{\circ} 54^{\prime} 53^{\prime \prime}$

Long. $84^{\circ} 18^{\prime} 24^{\prime \prime}$

$0 . R$. Grid Block G-8

Present Condition:

Function:

Standing

Barn

Tract No.:

Size:

Acquired from:

Structure No.:

Location:

30

159.3

E. W. Mckinney et al. $30 \mathrm{~A}$

Lat. $35^{\circ} 54^{\prime}$ '? ?"

Lurly. 84 $20^{\circ} 16^{\prime \prime}$

O.R. Grid Block G-6

Present Condition: Foundation only

Function:

Dwelling

Structure No.: $\quad 30 B$

Location:

Lat. $35^{\circ} 54^{\prime} 22^{\prime \prime}$

Long. $84^{\circ} 20^{\prime} 16^{\prime \prime}$

0. R. Grid Block G-6

Present Condition:

Function:

Foundation only

Undetermined

Structure No.: $\quad 30 \mathrm{C}$

Location: Lat. 35n54'22"

Long. 84 $20^{\circ} 16^{\prime \prime}$

$0 . R$. Grid Block G-6

Present Condition: Foundation only

Function:

Crib

Tract No.:

Size:

Acquired from:

Structure No.:

Location:

31

1.0

Board of Education

$31 \mathrm{~A}$

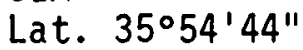

Long. 84०19'54"

$0 . R$. Grid Block F-6

Present Condition:

Function:
Foundation only

School 
Tract No.:

Size:

Acquired from:

Structure No.:

Location:

Present Condition:

Function:

Structure No.:

Location:

Present Condition:

Function:

Structure No.:

Location:

Present Condition:

Function:

Structure No.: Location:

Present Condition:

Function:

Structure No.:

Location:

Present Condition:

Function:

Structure No.:

Structure
Location:

Present Condition:

Function:

Structure No.: Location:

Present Condition: Function:
32

127.0

M. A. Wallace

$32 \mathrm{~A}$

Lat. $35^{\circ} 54^{\prime} 29^{\prime \prime}$

Long. $84^{\circ} 20^{\prime} 08^{\prime \prime}$

$0 . R$. Grid Block G-6

Foundation only

Dwel 1 ing

$32 B$

Lat. $35^{\circ} 54^{\prime} 29^{\prime \prime}$

Long. $84^{\circ} 20^{\prime} 08^{\prime \prime}$

$0 . R$. Grid Block G-6

Standing

Crib

$32 \mathrm{C}$

Lat. $35^{\circ} 54^{\prime} 29^{\prime \prime}$

Long. $84^{\circ} 20^{\prime} 08^{\prime \prime}$

O.R. Grid Block G-6

Foundation only

Smokehouse

$32 D$

Lat. $35^{\circ} 54^{\prime} 29^{\prime \prime}$

Long. 84 $4^{\circ} 20^{\prime} 08^{\prime \prime}$

$0 . R$. Grid Block G-6

Partially standing

Henhouse

$32 \mathrm{E}$

Lat. $35^{\circ} 54^{\prime} 27^{\prime \prime}$

Long. $84^{\circ} 20^{\prime} 09^{\prime \prime}$

0. R. Grid Block G-6

Foundation only

Dwelling.

$32 \mathrm{~F}$

Lat. $35^{\circ} 54^{\prime} 27^{\prime \prime}$

Long. $84^{\circ} 20^{\prime} 09^{\prime \prime}$

$0 . R$. Grid Block G-6

Partially standing

Undetermined

$32 G$

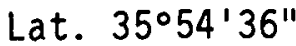

Long. 84 $4^{\circ} 19^{\prime} 48^{\prime \prime}$

$0 . R$. Grid Block G-6

Foundation only

Dwelling 
Tract No.

Size:

Acquired from:

Structure No.:

Location:

Present Condition:

Function:

Structure No.: Location:

Present Condition: Function:

Tract No.:

Size:

Acquired from:

Structure No.

Location:

Present Condition Function:

Structure No.: Location:

Present Condition:

Function:

Structure No.: Location:

Present Condition:

Function:

Structure No.:

Location:

Present Condition: Function:

Structure No.: Location:

Present Condition: Function:
33

276.7

H. M. Robertson heirs $33 \mathrm{~A}$

Lat. $35^{\circ} 54^{\prime} 10^{\prime \prime}$

Long. $84^{\circ} 19^{\prime} 51^{\prime \prime}$

$0 . R$. Grid Block G-6

Foundation only

Dwelling

$33 B$

Lat. $35^{\circ} 54^{\prime} 03^{\prime \prime}$

Long. 84 $19^{\prime} 52^{\prime \prime}$

$0 . R$. Grid Block G-6

Foundation only

Dwelling

37

37.8

Carl and Maggie McKeehan

$37 \mathrm{~A}$

Lat. $35^{\circ} 53^{\prime} 42^{\prime \prime}$

l.ong. $844^{\circ} 18158^{\prime \prime}$

0.R. Grid Block H-6

Standing

Dwelling

$37 \mathrm{~B}$

Lat. $35^{\circ} 53^{\prime} 49^{\prime \prime}$

Long. $84^{\circ} 14^{\prime} 00^{\prime \prime}$

0. R. Grid Block H-6, H-7

Foundation only

Dwelling

$37 \mathrm{C}$

Lat. $35^{\circ} 53^{\prime} 50^{\prime \prime}$

Long. $84^{\circ} 19^{\prime} 00^{\prime \prime}$

$0 . R$. Grid Block H-6, H-7

Partially standing

Storage

370

Lat. $35^{\prime \prime} 53^{\prime} 50^{\prime \prime}$

Long. $84^{\circ} 19^{\prime} 00^{\prime \prime}$

$0 . R$. Grid Block $H-6, H-7$

Foundation only

Undetermined

$37 \mathrm{E}$

Lat. $35^{\circ} 53^{\prime} 52^{\prime \prime}$.

Long. 81'18'58"

$0 . R$. Grid Block $\mathrm{H}-6, \mathrm{H}-7$

Partially standing

Barn 
Tract No.:

Size:

Acquired from:

Structure No.:

Location:

Present Condition:

Function:

Location:
Structure No.:

38

37.0

A. L. Babb

$38 \mathrm{~A}$

Lat. $35^{\circ} 53^{\prime} 50^{\prime \prime}$

Long. $84^{\circ} 18^{\prime} 54^{\prime \prime}$

$0 . R$. Grid Block H-7

Standing

Barn

38B

Lat. $35^{\circ} 53^{\prime} 53^{\prime \prime}$

Long. $84^{\circ} 18^{\prime} 56^{\prime \prime}$

$0 . R$. Grid Block H-7

Present Condition: Standing

Function:

Undetermined

Structure No.:

$38 \mathrm{C}$

Location:

Lat. $35^{\circ} 53^{\prime} 51^{\prime \prime}$

Long. $84^{\circ} 18^{\prime} 50^{\prime \prime}$

$0 . R$. Grid Block $\mathrm{H}-7$

Present Condition: Partially standing

Function:

Dwelling

Structure No.: $\quad 380$

Location:

Lat. $35^{\circ} 53^{\prime} 51^{\prime \prime}$

Long. $84^{\circ} 18^{\prime} 53^{\prime \prime}$

$0 . \mathrm{R}$. Grid Block $\mathrm{H}-7$

Present Condition: Partially standing

Function:

Crib

Structure No.: $\quad 38 \mathrm{E}$

Location:

$38 \mathrm{E}$

Lat. $35^{\circ} 53^{\prime} 49^{\prime \prime}$

Long. $84^{\circ} 18^{\prime} 52^{\prime \prime}$

$0 . R$. Grid Block H-7

Present Condition:

Standing

Function:

Barn

Structure No.:

$38 \mathrm{~F}$

Location:

Lat. $35^{\circ} 53^{\prime} 50^{\prime \prime}$

Long. 84 $18^{\prime} 53^{\prime \prime}$

$0 . R$. Firid Block H-7

Present Condition:

Function:

Standing

Fence

Tract No.:

39

Size:

Acquired from:

Structure No.:

Location:

109.0

James Comer

$39 \mathrm{~A}$

Lat. $35^{\circ} 53^{\prime} 51^{\prime \prime}$

Long. $84^{\circ} 18^{\prime} 40^{\prime \prime}$

$0 . R$. Grid Block H-7

Present Condition:

Function:
Foundation only

Dwelling 


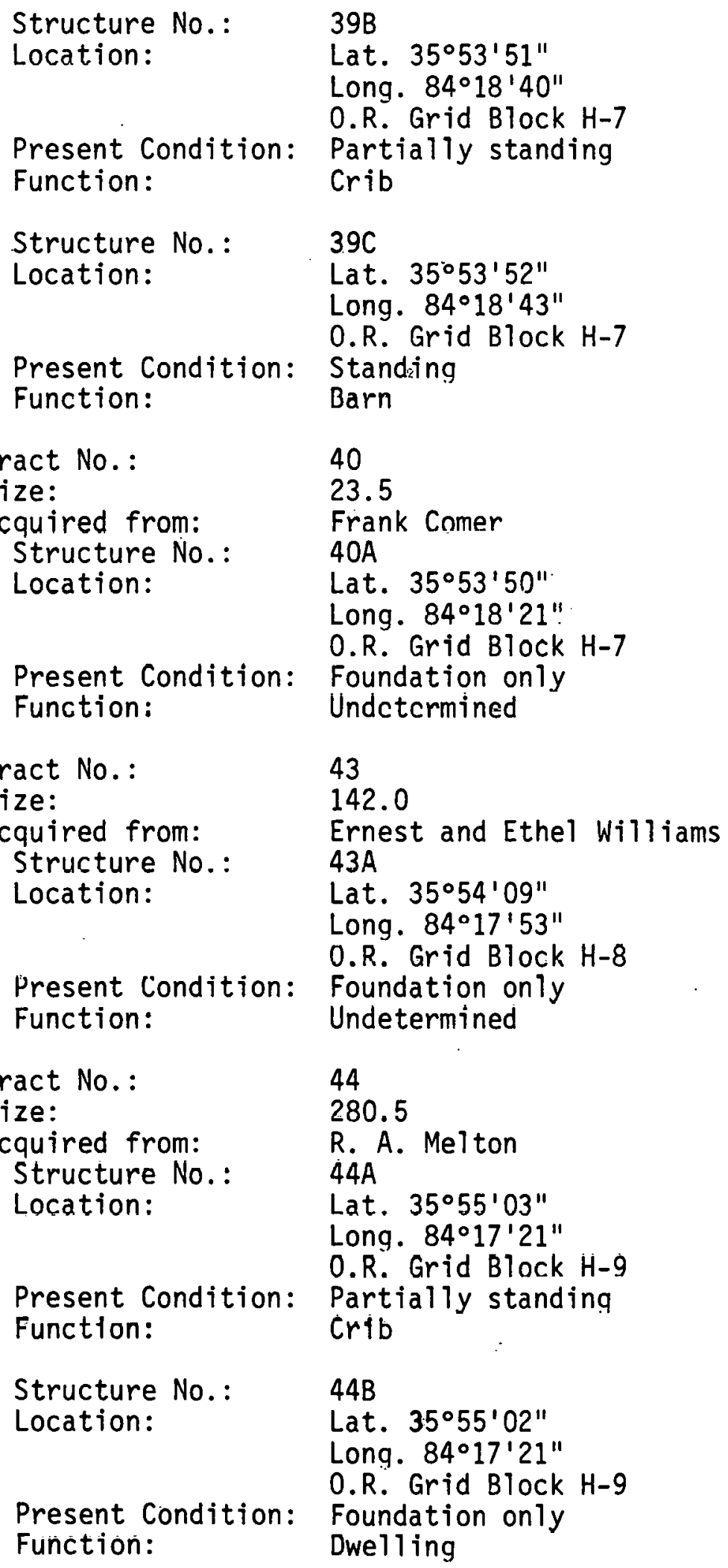




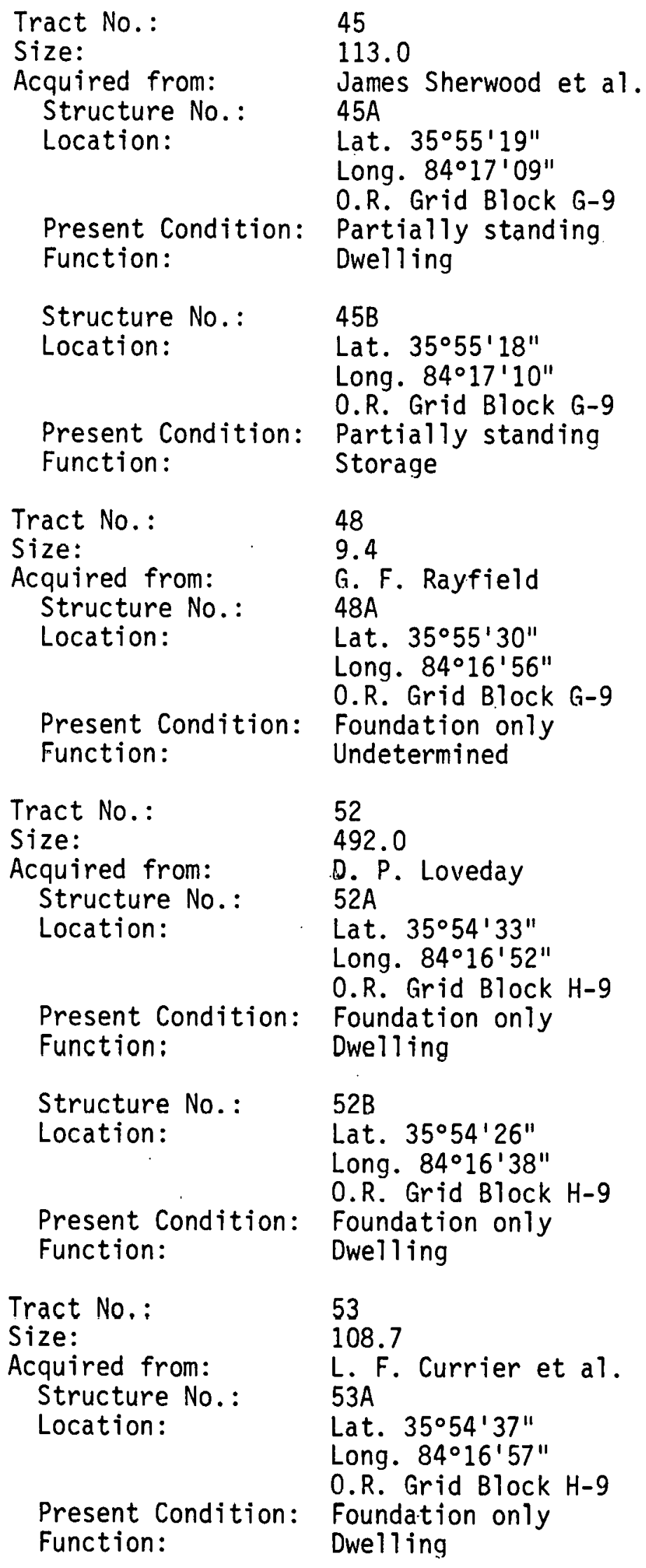




$\begin{array}{ll}\text { Structure No.: } & 53 \mathrm{~B} \\ \text { Location: } & \text { Lat. } 35^{\circ} 54^{\prime} 37^{\prime \prime} \\ & \text { Long. } 84^{\circ} 16^{\prime} 57^{\prime \prime} \\ & \text { O.R. Grid Block H-9 } \\ \text { Present Condition: } & \begin{array}{l}\text { Partially standing } \\ \text { Cunction: }\end{array} \\ \text { Crib }\end{array}$

Structure No.: $\quad 53 \mathrm{C}$

Location: Lat. $35^{\circ} 54^{\prime} 37^{\prime \prime}$

Long. $84^{\circ} 16^{\prime} 57^{\prime \prime}$

Present Condition: Grid Block H-9

Function: Foundation only

Tract No.: $\quad 54$

Size: $\quad 89.5$

Acquired from: Kent McLain

Structure No.: $\quad 54 \mathrm{~A}$

Location: Lat. $\quad 35^{\circ} 54^{\prime} 32^{\prime \prime}$

Long. $84 \circ 17 ! 37 ! \prime$

0.R. Grid Block $H-8$

Present Condition: Partially standing

Function:

Dwelling

Structure No.: $\quad 54 \mathrm{~B}$

Location: $\quad$ Lat. $35^{\circ} 54^{\prime} 32^{\prime \prime}$

Long. $84^{\circ} 17^{\prime} 37^{\prime \prime}$

O.R, Grid Block $\mathrm{H}-8$

Present Condition: Partially standing

Function: Crib

Tract No.: 55

Size: $\quad 146.3$

Acquired from: Allison Clough

Structure No.: $\quad 55 \mathrm{~A}$

Location: lat. $35^{\circ} 54^{\prime} 13^{\prime \prime}$

Long. $84^{\circ} 17^{\prime} 26^{\prime \prime}$

$0 . R$. Grid Block H-8

Present Condition: Partially standing

Function: Dwelling

Structure No.: $\quad 55 B$

Location: Lat. $35^{\circ} 54^{\prime} 12^{\prime \prime}$

Long. $84^{\circ} 17^{\prime} 22^{\prime \prime}$

$0 . \mathrm{R}$. Grid Block H-8

Present Condition: Partially standing

Function: Barn

Structure No.: $\quad 55 \mathrm{C}$

Location: Lat. $35^{\circ} 54^{\prime} 03^{\prime \prime}$

Long. $84^{\circ} 17^{\prime} 15^{\prime \prime}$

O.R. Grid Block I-8

Present Condition: Partially standing

Function:

Dwelling 


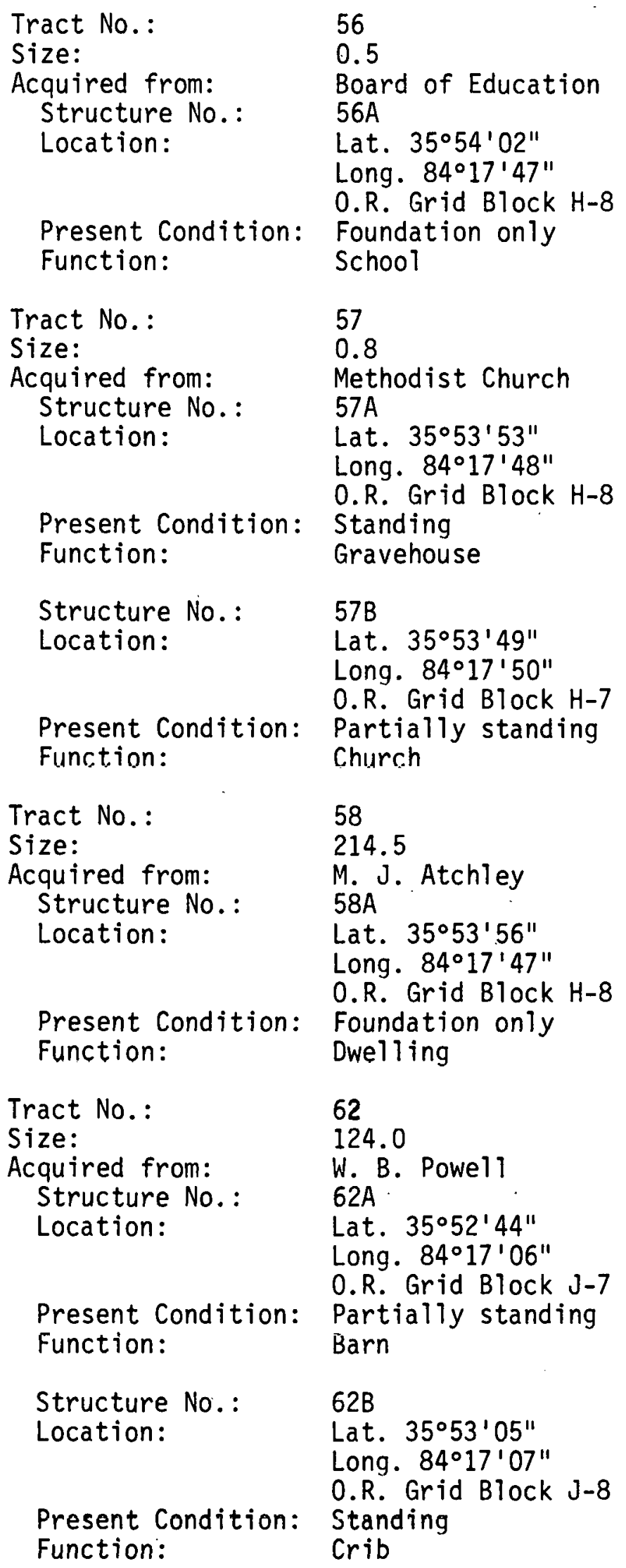


Tract No.:

Size:

Acquired from:

Structure No.:

Location:

Present Condition:

Function:

Tract No.:

Size:

Acquired from:

Structure No.:

Location:

Present Condition:

Function:

Structure No.:

Location:

Present Condition:

Function:

Structure No.: Location:

Present Condition: runction:

Tract No.:

Size:

Acquired from:

Structure No.: Location:
64

105.6

R. R. Atchley

$64 \mathrm{~A}$

Lat. $35^{\circ} 53^{\prime} 15^{\prime \prime}$

Long. 84 $14^{\circ} 26^{\prime \prime}$

0.R. Grid Block I-7

Partially standing

Dwelling

67

20.9

J. E. and Elza Loposser

$67 A$

Lat. $35^{\circ} 53^{\prime} 26^{\prime \prime}$

Long. $84^{\circ} 17^{\prime} 34^{\prime \prime}$

0. R. Grid Block I-7

Foundation only

Dwelling

67B

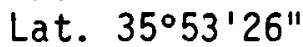

Long. 84'17'34"

0.R. Grid Block I-7

Partially standing

Undetermined

$67 C$

Lat. $35^{\circ} 53^{\prime} 26^{\prime \prime}$

Long. 84 $14^{\circ} 34^{\prime \prime}$

0.R. Grid Block I-7

Foundation only

Undetermined

68

36.3

J. A. and J. D. Peterson $68 \mathrm{~A}$

Lat. $35^{\circ} 53^{\prime} 33^{\prime \prime}$

Long. $84^{\circ} 17^{\prime} 42^{\prime \prime}$

0.R. Grid Block I-7

Present Condition: Foundation only Function:

Dwelling

Tract No.:

70

Size:

Acquired from:

Structure No.: Location:

138.5

Charles Powel1

$70 \mathrm{~A}$

Lat. $35^{\circ} 53^{\prime} 27^{\prime \prime}$

Long. $84^{\circ} 17^{\prime} 59^{\prime \prime}$

0. R. Grid Block I-7

Present Condition: Function:
Foundation only

Dwelling 


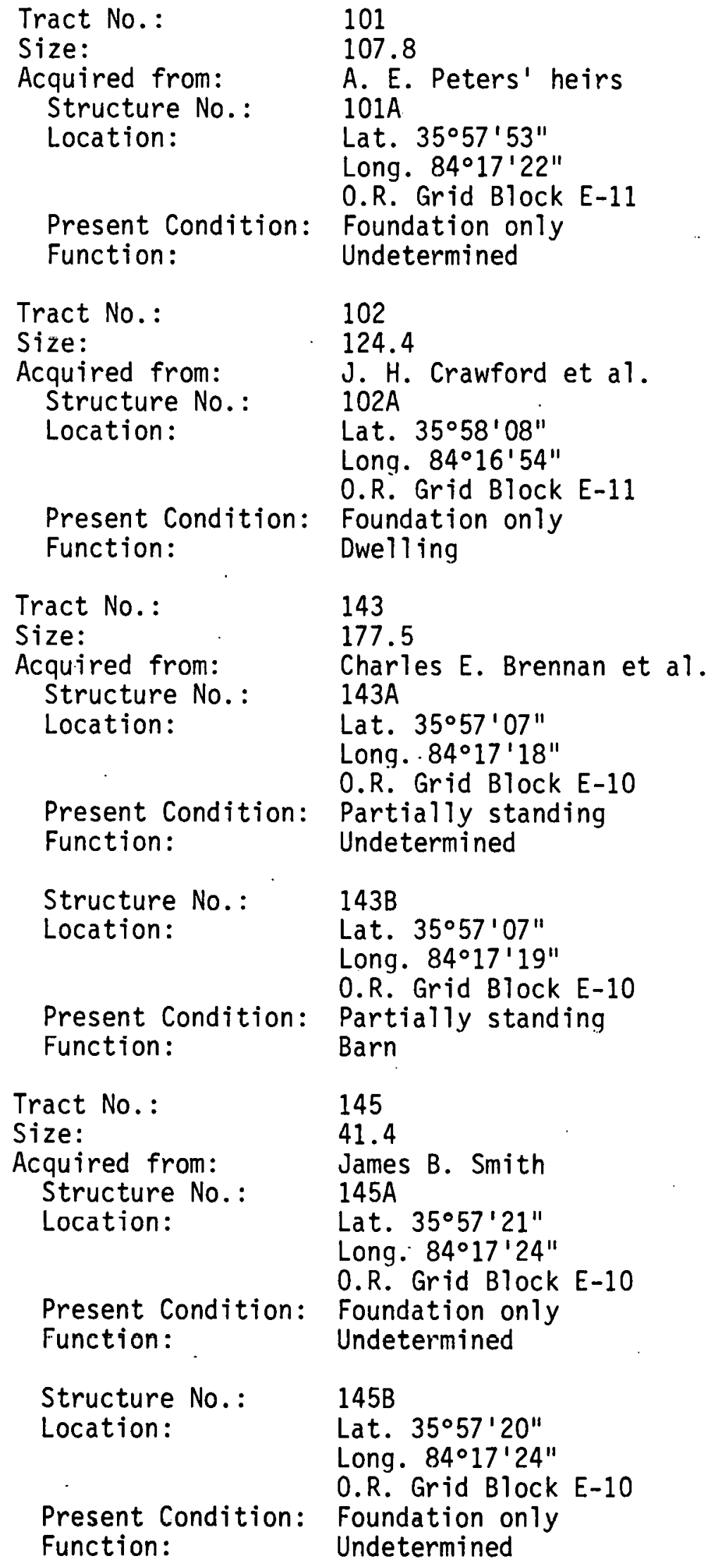




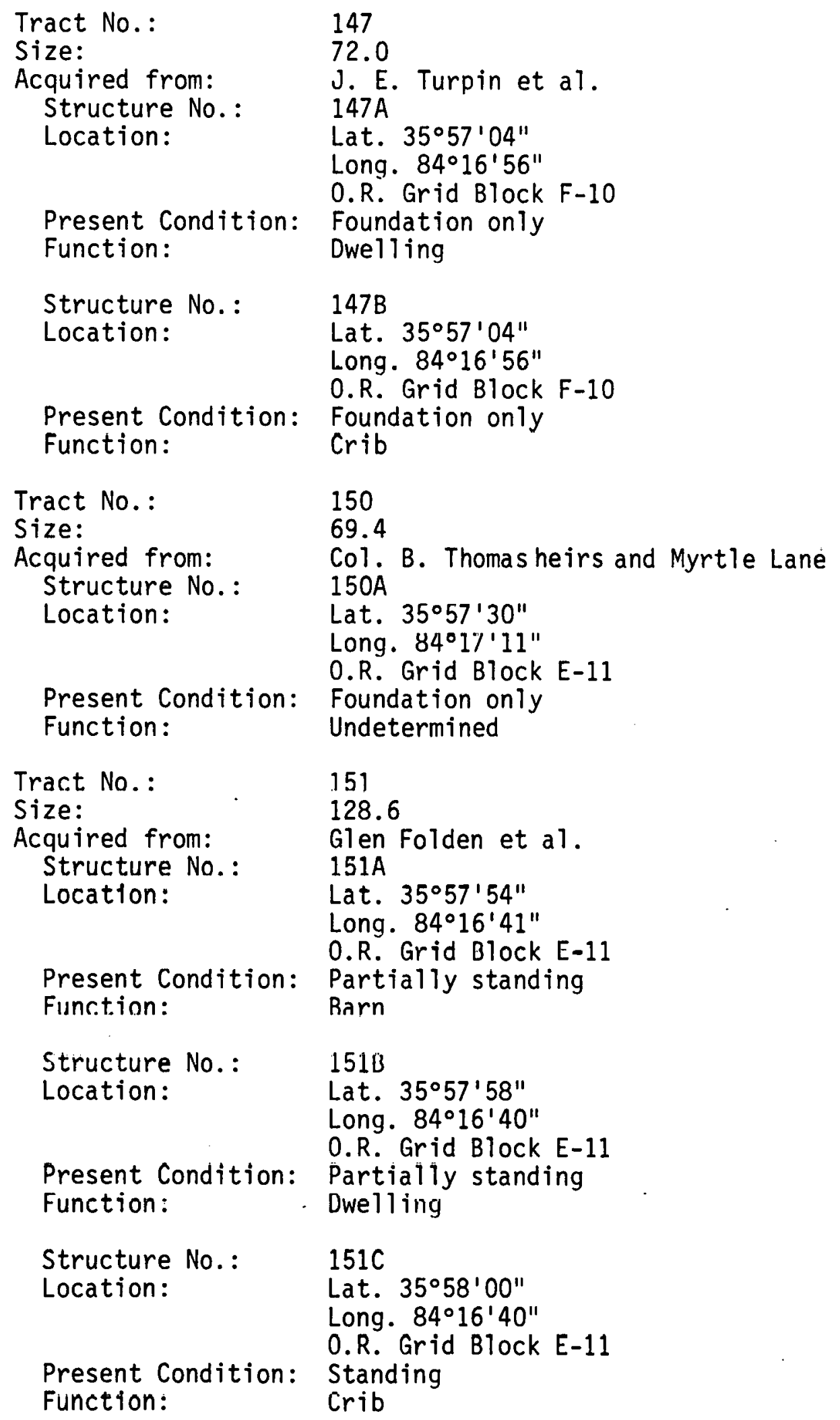


Structure No.: $\quad 1510$

Location: $\quad$ Lat. $35^{\circ} 57^{\prime} 56^{\prime \prime}$

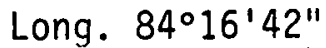

Present Condition: Standing

Function:

Henhouse

\begin{tabular}{|c|c|}
\hline $\begin{array}{l}\text { Tract No.: } \\
\text { Size: } \\
\text { Acquired from: } \\
\text { Structure No.: } \\
\text { Location: }\end{array}$ & $\begin{array}{l}152 \\
103.6 \\
\text { West L. Dunaway } \\
152 A \\
\text { Lat. } 35^{\circ} 58^{\prime} 16^{\prime \prime} \\
\text { Long. } 84^{\circ} 16^{\prime} 09^{\prime \prime} \\
\text { O.R. Grid Block E-12 } \\
\text { Foundation only } \\
\text { Dwelling }\end{array}$ \\
\hline $\begin{array}{l}\text { Tract No.: } \\
\text { Size: } \\
\text { Acquired from: } \\
\text { Structure No.: } \\
\text { Location: }\end{array}$ & $\begin{array}{l}153 \\
41.1 \\
\text { Charles and John Allison } \\
153 A \\
\text { Lat. } 35^{\circ} 58^{\prime} 05^{\prime \prime} \\
\text { Long. } 84^{\circ} 16^{\prime} 08^{\prime \prime} \\
\text { O.R. Grid Block E-12 } \\
\text { Standing } \\
\text { Dwelling }\end{array}$ \\
\hline $\begin{array}{l}\text { Present Condition: } \\
\text { Function: }\end{array}$ & $\begin{array}{l}\text { 153B } \\
\text { Lat. } 35^{\circ} 58^{\prime} 05^{\prime \prime} \\
\text { Long. } 84^{\circ} 16^{\prime} 08^{\prime \prime} \\
\text { 0.R. Grid Block E-12 } \\
\text { Foundation only } \\
\text { Undetermined }\end{array}$ \\
\hline $\begin{array}{l}\text { Tract No.: } \\
\text { Size: } \\
\text { Acquired from: } \\
\text { Structure No.: } \\
\text { Location: }\end{array}$ & $\begin{array}{l}173 \\
34.9 \\
\text { llerman Jenkins } \\
173 A \\
\text { Lat. } 35^{\circ} 57^{\prime} 46^{\prime \prime} \\
\text { Long. } 84^{\circ} 15^{\prime} 46^{\prime \prime} \\
\text { 0.R. Grid Block F-12 } \\
\text { Partially standing } \\
\text { Dwelling }\end{array}$ \\
\hline $\begin{array}{l}\text { Tract No.: } \\
\text { Size: } \\
\text { Acquired from: } \\
\text { Structure No.: } \\
\text { Location: }\end{array}$ & $\begin{array}{l}174 \\
112.6 \\
\text { Ida B. Holloway } \\
174 A \\
\text { Lat. } 35^{\circ} 57^{\prime} 46^{\prime \prime} \\
\text { Long. } 84^{\circ} 15^{\prime} 46^{\prime \prime} \\
\text { 0.R. Grid Block F-12 } \\
\text { Foundation only } \\
\text { Dwelling }\end{array}$ \\
\hline
\end{tabular}




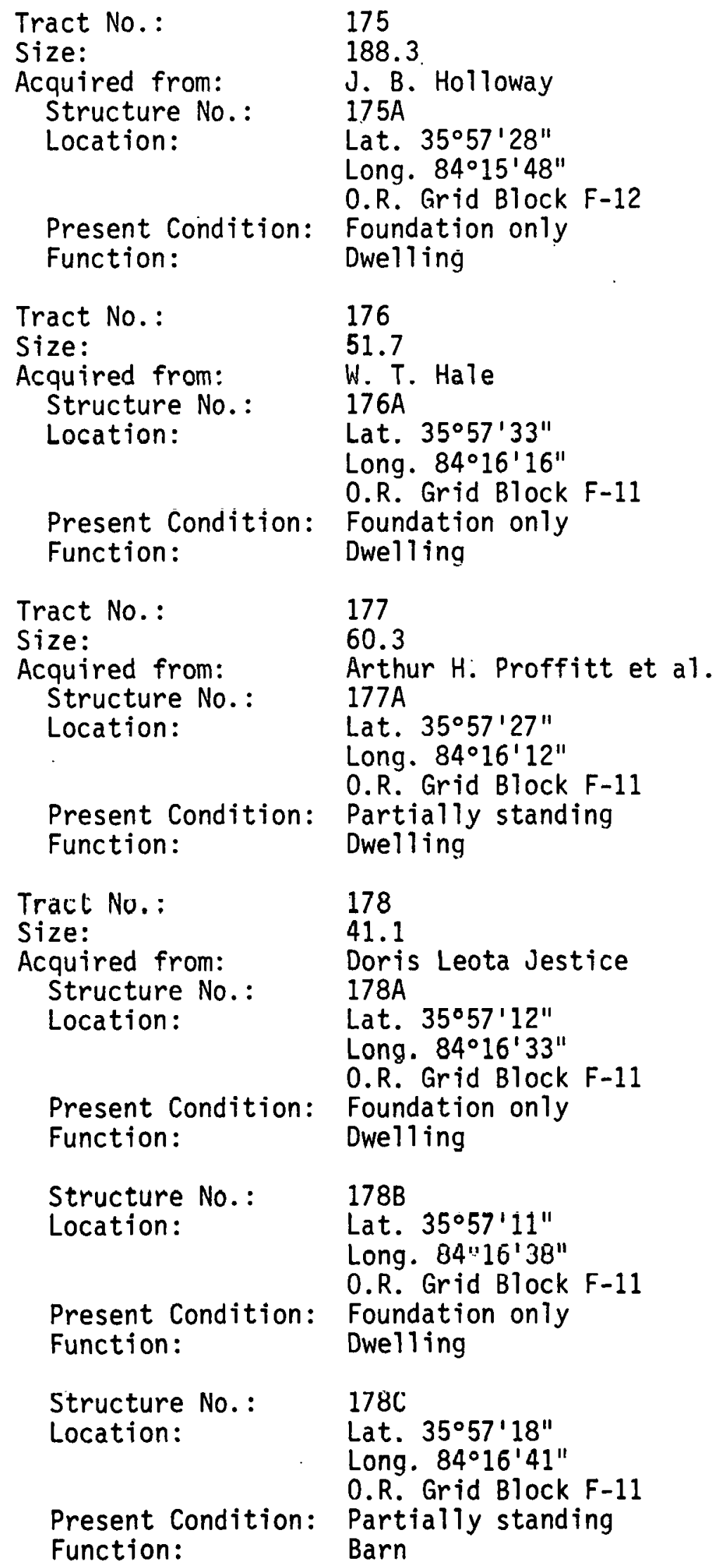




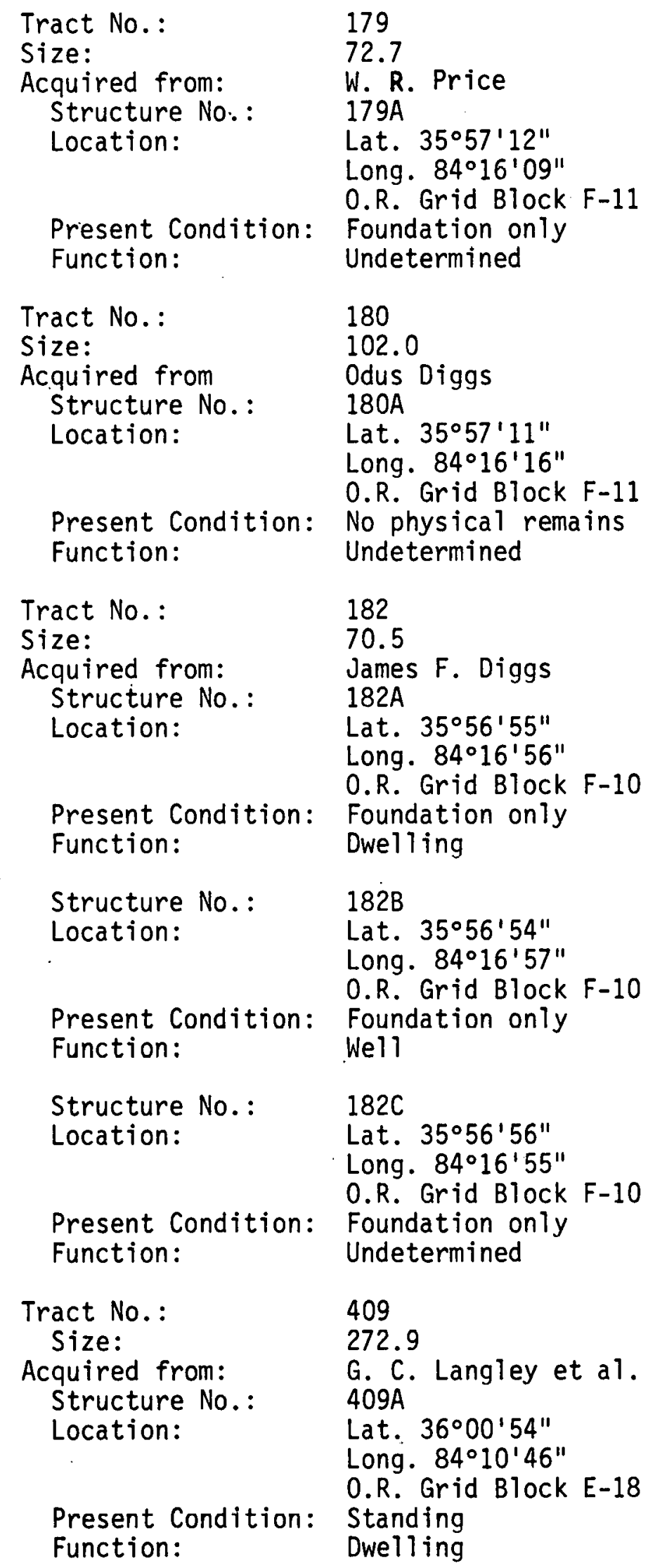


Structure No.: $\quad 409 B$

Location:

Lat. $36^{\circ} 00^{\prime} 53^{\prime \prime}$

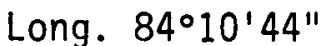

$0 . R$. Grid Block E-18

Present Condition: Standing

Function:

Garage and chicken coop

Structure No.: $\quad 409 \mathrm{C}$

Location:

Lat. $36^{\circ} 00^{\prime} 53^{\prime \prime}$

Long. $84^{\circ} 10^{\prime} 45^{\prime \prime}$

Present Condition: Standing

$0 . R$. Grid Block E-18

Function:

Storage

Structure No.: $\quad 4090$

Location:

Lat. $36^{\circ} 00^{\prime} 53^{\prime \prime}$

Long. $84^{\circ} 10^{\prime} 44^{\prime \prime}$

Present Condition: Standing

Function:

Privy

Tract No.:

413

S1zé:

Acquired from:

Structure No.:

418.5

J. L. Hockworth et al. $413 A$

Location:

Lat. $36^{\circ} 00^{\prime} 06^{\prime \prime}$

Long. $84^{\circ} 11^{\prime} 18^{\prime \prime}$

$0 . R$. Grid Block F-17

Present Condition: Standing

Function:

Dwelling

Structure No.:

413B

Location:

Lat. $36^{\circ} 00^{\prime} 08^{\prime \prime}$

Long. $84^{\circ} 11^{\prime} 16^{\prime \prime}$

0. R. Grid Block F-17

Present Condition: Standing

Function:

Barn-henhouse

Structure No.:

$413 C$

Location:

Lat. $36^{\circ} 00^{\prime} 03^{\prime \prime}$

Long. $84^{\circ} 11^{\prime} 12^{\prime \prime}$

$0 . R$. Grid Block F-17

Present Condition: Standing

Function:

Springhouse

Tract No.:

415

Size:

Acquired from:

Structure No.:

145.0

T. W. Fox

415A

Location:

Lat. $35^{\circ} 00^{\prime} 24^{\prime \prime}$

Long. $84^{\circ} 10^{\prime} 52^{\prime \prime}$

Present Condition:

$0 . R$. Grid Block F-18

Function:

Standing

Barn 


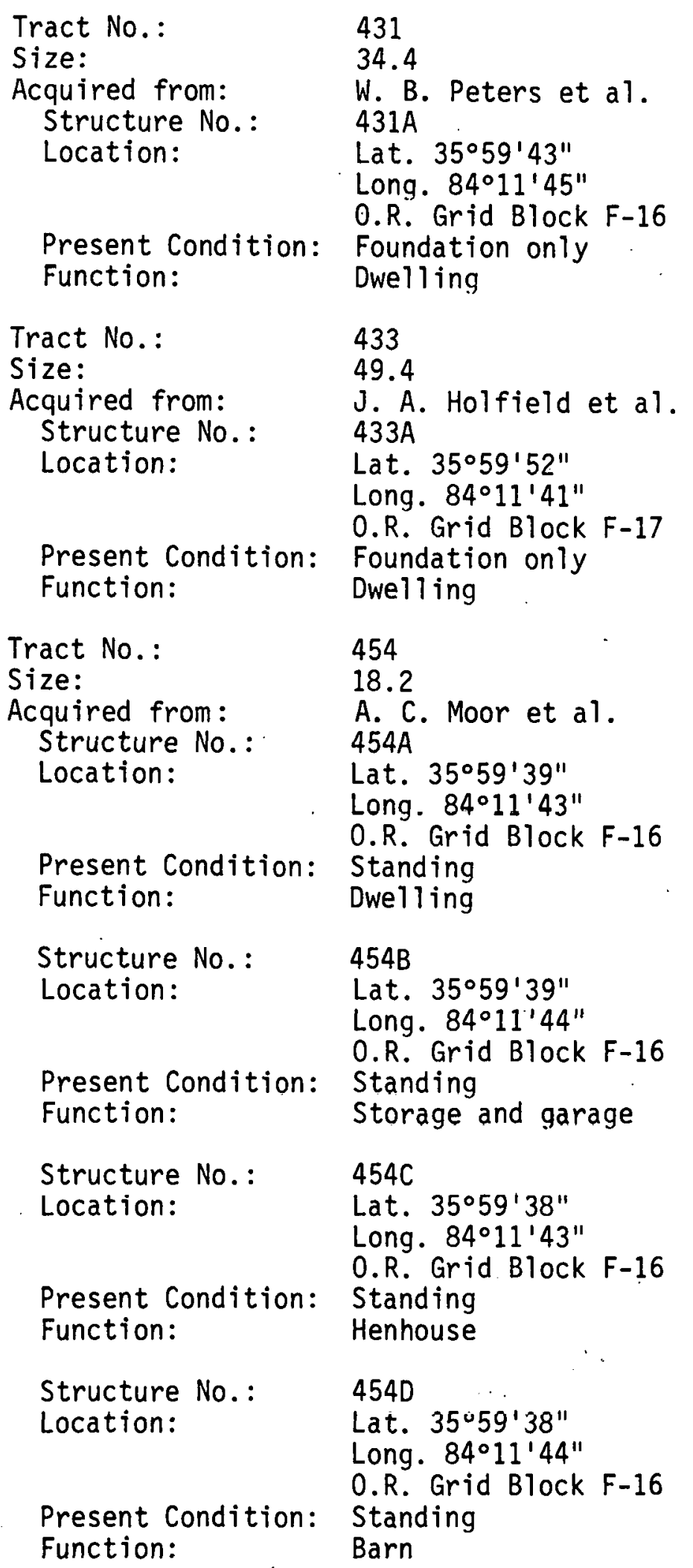


Tract No.:

Size:

Acquired from:

Structure No.:

Location:
601

390.0

Hiram P. Carter

$601 \mathrm{~A}$

Lat. $35^{\circ} 56^{\prime} 43^{\prime \prime}$

Long. $84^{\circ} 17^{\prime} 20^{\prime \prime}$

$0 . R$. Grid Block F-10

Present Condition:

Function:

Foundation only

Dwelling

Structure No.:

$601 \mathrm{~B}$

Location:

Lat. $35^{\circ} 56^{\prime} 43^{\prime \prime}$

Long. $84^{\circ} 17^{\prime} 20^{\prime \prime}$

$0 . R$. Grid Block F-10

Present Condition: Partially standing

Function:

Crib

Structure No.:

$601 \mathrm{C}$

Location:

Lat. $35^{\circ} 57^{\prime} 00^{\prime \prime}$

Long. $84^{\circ} 17^{\prime} 12^{\prime \prime}$

$0 . R$. Grid Block F-10

Present Condition:

Function:

Foundation only

Dwelling

Structure No.:

Location:

6010

Lat. $35^{\circ} 56^{\prime} 59^{\prime \prime}$

Long. $84^{\circ} 17^{\prime} 12^{\prime \prime}$

0.R. Grid Block F-10

Present Condition:

Function:

Partially standing

Crib

Structure No.:

Location:

Present Condition:

Function:

Trart. No.:

Size:

Acquired from:

Structure No.:

Location:

Present Condition:

Function:

Tract No.:

Size:

Acquired from:

Long. $84^{\circ} 17^{\prime} 11^{\prime \prime}$
601E

Lat. 35056 '40"

$0 . \bar{R}$. Grid Block F-10

Foundation only

Undetermined

602

16.8

Walter Huskey et al.

602A

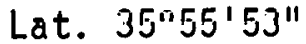

Long. $84^{\circ} 17^{\prime} 10^{\prime \prime}$

0.R. Grid Block G-9

Foundation only

Dwelling

603

0.4

Trustees of the Friendship Baptist Church 
Structure No.:

$603 A$

Location:

Lat. $35^{\circ} 55^{\prime} 48^{\prime \prime}$

Long. $84^{\circ} 17^{\prime} 04^{\prime \prime}$

0.R. Grid Block G-9

Present Condition: Foundation only

Function:

Church

Tract No.:

606

Size:

15.0

Acquired from:

Structure No.:

G. F. Rayfield

Location:

$606 \mathrm{~A}$

Lat. $35^{\circ} 55^{\prime} 26^{\prime \prime}$

Long. $84^{\circ} 16^{\prime} 46^{\prime \prime}$

$0 . R$. Grid Block G-9

Present Condition: No physical remains

Function:

Undetermined

Tract No.:

607

Size:

27.2

Acquired from:

Structure No.:

Pollie A. Whaley

$607 \mathrm{~A}$

Location:

Lat. $35^{\circ} 55^{\prime} 23^{\prime \prime}$

Long. $84^{\circ} 16^{\prime} 26^{\prime \prime}$

O.R. Grid Block H-10

Present Condition: Foundation only

Function:

Undetermined

Tract No.:

609

Size:

62.3

Acquired from:

Structure No.:

Location:

D. P. Loveday et ux, et al. 609A

Lat. $35^{\circ} 54^{\prime} 53^{\prime \prime}$

Long. $84^{\circ} 16^{\prime} 22^{\prime \prime}$

$0 . R$. Grid Block H-9

Present Condition: Partially standing

Function:

Barn

Tract No.:

610

Size:

176.2

Acquired from:

Structure No.:

Henry Price

Location:

610A

Lat. $35^{\circ} 55^{\prime} 13^{\prime \prime}$

Long. $84^{\circ} 16^{\prime} 07^{\prime \prime}$

$0 . R$. Grid Block H-10

Present Condition:

Foundation only

Function:

Dwelling

Structure No.: $\quad$ 610B

Location:

Lat. $35^{\circ} 55^{\prime} 07^{\prime \prime}$

Long. $84^{\circ} 16^{\prime} 08^{\prime \prime}$

$0 . R$. Grid Block H-10

Present Condition: Foundation only

Function:

Dwelling 
Structure No.: $\quad 610 \mathrm{C}$

Location:

Lat. $35^{\circ} 55^{\prime} 07^{\prime \prime}$

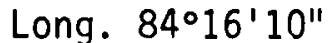

$0 . R$. Grid Block $\mathrm{H}-10$

Present Condition: Partially standing

Function:

Barn

Structure No.: $\quad 6100$

Location: Lat. $35^{\circ} 55^{\prime} 01^{\prime \prime}$

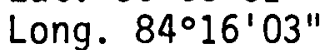

$0 . R$. Grid Block $H-10$

Present Condition: Foundation only

Function: Dwelling

Structure No.: $\quad 610 \mathrm{E}$

Location: Lat. $35^{\circ} 54^{\prime} 54^{\prime \prime}$

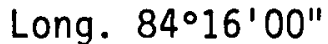

$0 . R$. Grid Block $\mathrm{H}-10$

Present Condition: Foundation only

Function:

Barn

Structure No.: $\quad 610 \mathrm{~F}$

Location: Lát. 35'54'54"

Long. $84^{\circ} 16^{\prime} 00^{\prime \prime}$

$0 . R$. Grid Block $H-10$

Present Condition: Foundation only

Function: Undetermined

Structure No.: $\quad 610 \mathrm{G}$

Location: Lat. $\quad 35^{\circ} 54^{\prime} 49^{\prime \prime}$

Luny. $84^{\circ} 16^{\prime} 12^{\prime \prime}$

$0 . R$. Grid Block H-9

Present Condition: Foundation only

Function: Dwelling

Tract No.: $\quad 611$

Size:

Acquired from:

Structure No.:

146.8

Location:

Earl Stringfield

$611 A$

Lat. $35^{\circ} 55^{\prime} 10^{\prime \prime}$

Long. $84^{\circ} 15^{\prime} 37^{\prime \prime}$

$0 . R$. Grid Block H-10

Present Condition: Standing

Function: Dwelling

Structure No.: $\quad 611 B$

Location: Lat. $35^{\circ} 55^{\prime} 10^{\prime \prime}$

Long. $8^{\circ} 15^{\prime} 37^{\prime \prime}$

0.R. Grid Block H-10

Present Condition: Foundation only

Function: Undetermined 


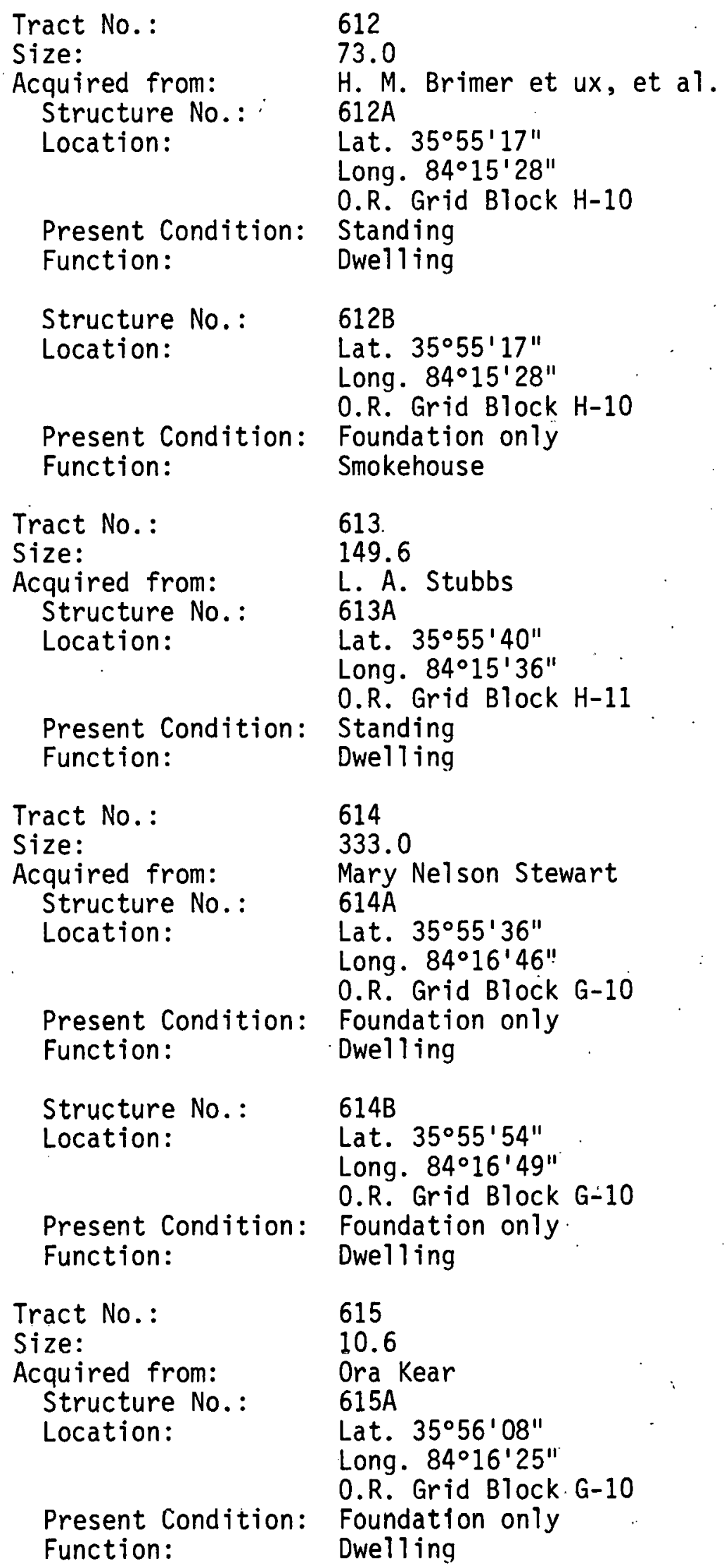




\begin{tabular}{|c|c|}
\hline $\begin{array}{l}\text { Present Condition: } \\
\text { Function: }\end{array}$ & $\begin{array}{l}615 B \\
\text { Lat. } 35^{\circ} 56^{\prime} 06^{\prime \prime} \\
\text { Long. } 84^{\circ} 16^{\prime} 27^{\prime \prime} \\
0 . R \text {. Grid Block G-10 } \\
\text { Foundation only } \\
\text { Storage and garage }\end{array}$ \\
\hline $\begin{array}{l}\text { Tract No.: } \\
\text { Size: } \\
\text { Acquired from: } \\
\text { Structure No.: } \\
\text { Location: }\end{array}$ & $\begin{array}{l}616 \\
27.7 \\
\text { C. C. Green et ux. } \\
616 \mathrm{~A} \\
\text { Lat. } 35^{\circ} 56^{\prime} 02^{\prime \prime} \\
\text { Long. } 84^{\circ} 16^{\prime} 31^{\prime \prime} \\
\text { O. R. Grid Block G-10 } \\
\text { Foundation only } \\
\text { Dwelling. }\end{array}$ \\
\hline $\begin{array}{l}\text { Tract No.: } \\
\text { Size: } \\
\text { Acquired from: } \\
\text { Structure No.: } \\
\text { Location: }\end{array}$ & $\begin{array}{l}617 \\
68.7 \\
\text { Tom Rayfield } \\
617 \text { A } \\
\text { Lat. } 35^{\circ} 56^{\prime} 08^{\prime \prime} \\
\text { Long. } 84^{\circ} 16^{\prime} 52^{\prime \prime} \\
0 . \text { R. Grid Block G-10 } \\
\text { Foundation only } \\
\text { Dwelling }\end{array}$ \\
\hline $\begin{array}{l}\text { Tract No.: } \\
\text { Size: } \\
\text { Acquired from: } \\
\text { Structure No.: } \\
\text { Location: }\end{array}$ & $\begin{array}{l}619 \\
21.6 \\
\text { Fred Kear et ux. } \\
619 A \\
\text { Lat. } 35^{\circ} 56^{\prime} 21^{\prime \prime} \\
\text { Long. } 84^{\circ} 16^{\prime} 32^{\prime \prime} \\
\text { O.R. Grid Block G-10 } \\
\text { Foundation only } \\
\text { Undetermined }\end{array}$ \\
\hline $\begin{array}{l}\text { Present Condition: } \\
\text { Function: }\end{array}$ & $\begin{array}{l}619 B \\
\text { Lat. } 35^{\circ} 56^{\prime} 21^{\prime \prime} \\
\text { Long. } 84^{\circ} 16^{\prime} 29^{\prime \prime} \\
\text { O.R. Grid Block G-10 } \\
\text { Foundation only } \\
\text { Dwelling }\end{array}$ \\
\hline $\begin{array}{l}\text { Tract No: : } \\
\text { Size: } \\
\text { Acquired from: } \\
\text { Structure No.: } \\
\text { Location: }\end{array}$ & $\begin{array}{l}622 \\
36.0 \\
\text { Isham Proffitt } \\
622 \mathrm{~A} \\
\text { Lat. } 35^{\circ} 56^{\prime} 28^{\prime \prime} \\
\text { Lung. } 84^{\circ} 16^{\prime} 30^{\prime \prime} \\
0 . \text {. Grid Block G-10 } \\
\text { Standing } \\
\text { Henhouse }\end{array}$ \\
\hline
\end{tabular}




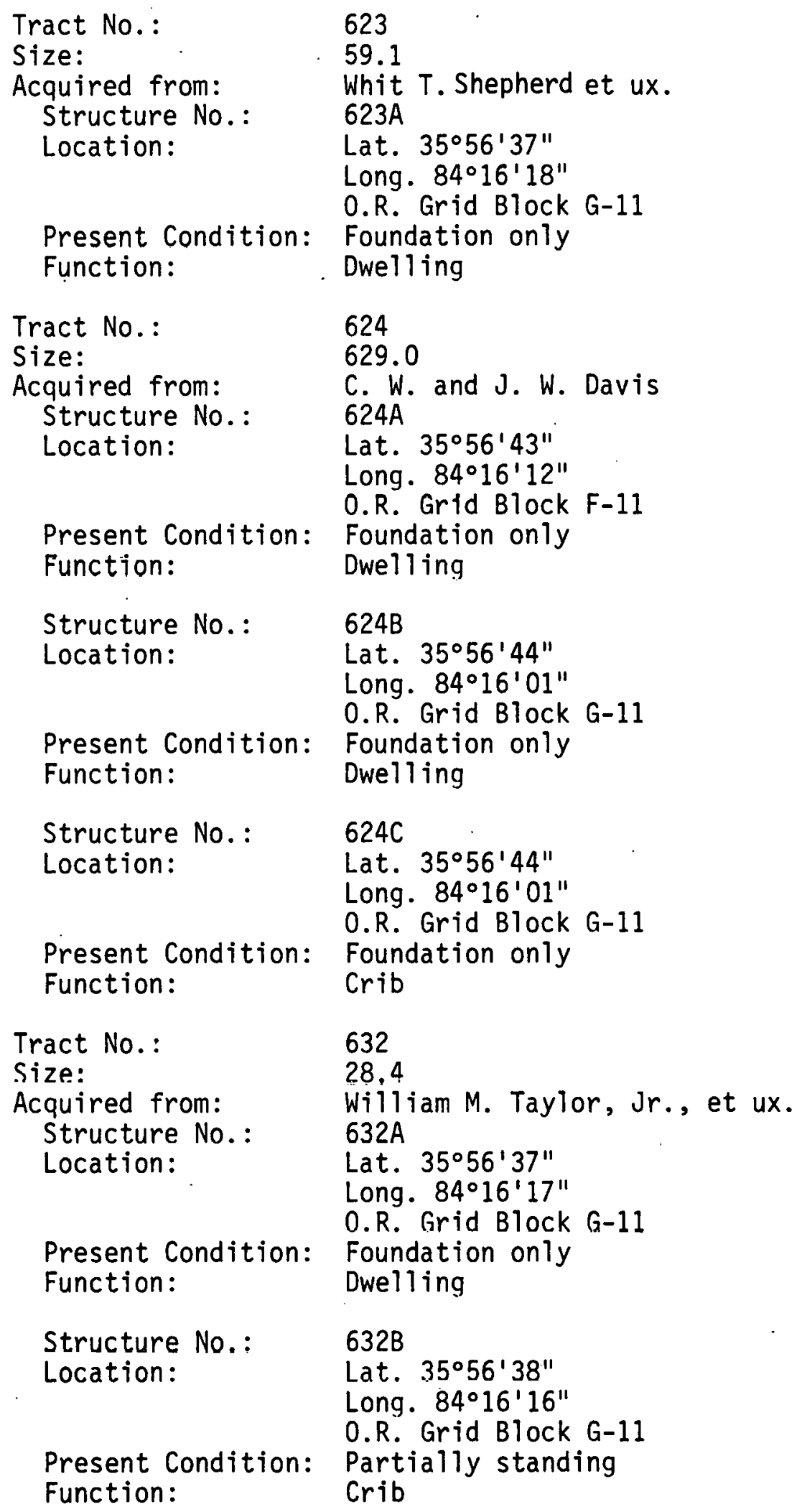




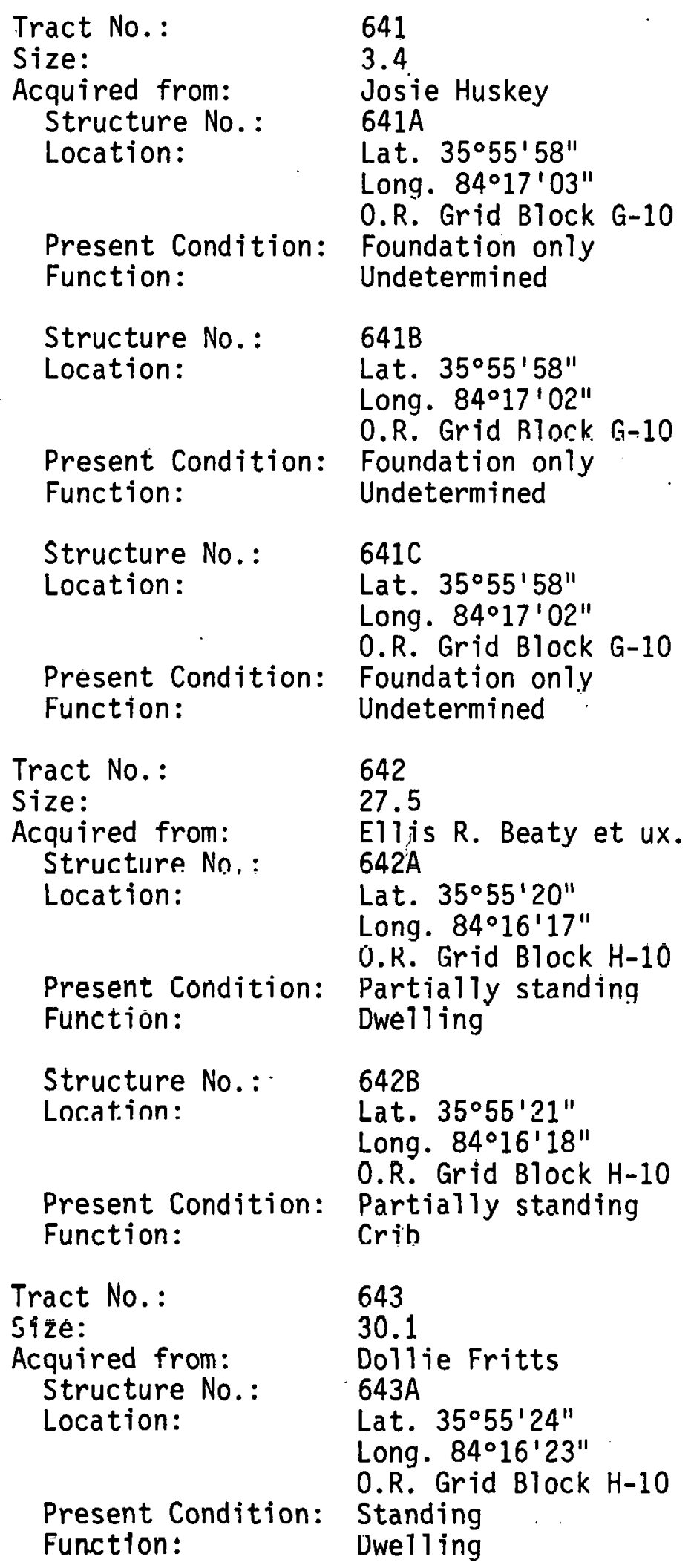




\begin{tabular}{|c|c|}
\hline $\begin{array}{l}\text { Present Condition: } \\
\text { Function: }\end{array}$ & $\begin{array}{l}643 B \\
\text { Lat. } 35^{\circ} 55^{\prime} 23^{\prime \prime} \\
\text { Long. } 84^{\circ} 16^{\prime} 24^{\prime \prime} \\
\text { O.R. Grid Block H-10 } \\
\text { Standing } \\
\text { Crib }\end{array}$ \\
\hline $\begin{array}{l}\text { Tract No.: } \\
\text { Size: } \\
\text { Acquired from: } \\
\text { Structure No.: } \\
\text { Location: }\end{array}$ & $\begin{array}{l}702 \\
72.6 \\
\text { D.M. Jones } \\
702 A \\
\text { Lat. } 35^{\circ} 56^{\prime} 46^{\prime \prime} \\
\text { Long. } 84^{\circ} 22^{\prime} 53^{\prime \prime} \\
\text { O.R. Grid Block C-5 } \\
\text { Foundation only } \\
\text { Dwelling }\end{array}$ \\
\hline $\begin{array}{l}\text { Present Condition: } \\
\text { Function: }\end{array}$ & $\begin{array}{l}\text { 702B } \\
\text { Lat. } 35^{\circ} 56^{\prime} 51^{\prime \prime} \\
\text { Long. } 84^{\circ} 22^{\prime} 54^{\prime \prime} \\
0 . R \text {. Grid Block C-5 } \\
\text { Foundation only } \\
\text { Dwelling }\end{array}$ \\
\hline $\begin{array}{l}\text { Tract No.: } \\
\text { Size: } \\
\text { Acquired from: } \\
\text { Structure No.: } \\
\text { Location: }\end{array}$ & $\begin{array}{l}704 \\
79.0 \\
\text { Charles McKinney } \\
704 \mathrm{~A} \\
\text { Lat. } 35^{\circ} 56^{\prime} 52^{\prime \prime} \\
\text { Long. 84 } 22^{\prime} 15^{\prime \prime} \\
\text { 0.R. Grid Block C-6 } \\
\text { Foundation only } \\
\text { Dwelling }\end{array}$ \\
\hline $\begin{array}{l}\text { Tract No.: } \\
\text { Size: } \\
\text { Acquired from: } \\
\text { Structure No.: } \\
\text { Location: }\end{array}$ & $\begin{array}{l}707 \\
122.0 \\
\text { T.j. J. Moneymaker } \\
707 \mathrm{~A} \\
\text { Lat. } 35^{\circ} 56^{\prime} 47^{\prime \prime} \\
\text { Long. } 84^{\circ} 21^{\prime} 43^{\prime \prime} \\
0 . \text { R. Grid Block C-6 } \\
\text { Foundation only } \\
\text { Dwelling }\end{array}$ \\
\hline $\begin{array}{l}\text { Tract No.: } \\
\text { Size: } \\
\text { Acquired from: } \\
\text { Structure No.: } \\
\text { Location: }\end{array}$ & $\begin{array}{l}712 \\
22.7 \\
\text { Julia Waller } \\
712 A \\
\text { Lat. } 35^{\circ} 56^{\prime} 28^{\prime \prime} \\
\text { Long. } 84^{\circ} 22^{\prime} 07^{\prime \prime} \\
0 . R \text {. Grid Block C-6 } \\
\text { Foundation only } \\
\text { Well house }\end{array}$ \\
\hline
\end{tabular}


Tract No.:

Size:

Acquired from:

Structure No.:

Location:
714

6.0

Nancy and Roy May

$714 \mathrm{~A}$

Lat. $35^{\circ} 56^{\prime} 39^{\prime \prime}$

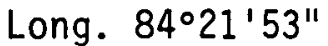

0.R. Grid Block C-6

Present Condition: Foundation only

Function:

Dwelling

Tract No.:

Size:

Acquired from:

Structure No.:

Location:

Present Condition:

Function:

Tract No.:

Size:

Acquired from:

Structure No.:

Location:

Present Condition:

Function:

Tract No.:

Slze:

Acquired from:

Structure No.:

Location:

Present Condition:

Functionn:

Tract No.:

Size:

Acquired froulll:

Structure No.:

Location:

Present Condition:

Function:
748

0.5

Board of Education

748A

Lat. $35^{\circ} 55^{\prime} 01^{\prime \prime}$

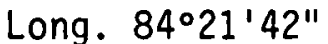

$0 . R$, Grid Block E-5

Foundation only

Dwelling

750

1.5

New Zion Baptist Church

$750 \mathrm{~A}$

Lat. $35^{\circ} 54^{\prime} 53^{\prime \prime}$

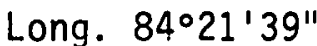

O.R. Grid Block E-5

Foundation only

Church

762

171.0

J. A. and Cora Cooper

$762 \mathrm{~A}$

Lat. $35^{\circ} 54^{\prime} 16^{\prime \prime}$

Long. $84^{\circ} 21^{\prime} 10^{\prime \prime}$

$0 . R$. Grid Block F-5

Partially standing

Crib

\section{3}

41.7

E. B. Thacker

$763 A$

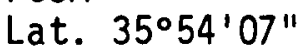

Long. $84^{\circ} 21^{\prime} 16^{\prime \prime}$

$0 . R$. Grid Block F-5

Standing

Smokehouse 
Tract No.:

Size:

Acquired from:

Structure No.:

Location:

Present Condition:

Function:

Tract No.:

Size:

Acquired from:

Structure No.:

Location:
801

133.0

A. L. Robinette

$801 \mathrm{~A}$

Lat. $35^{\circ} 57^{\prime} 26^{\prime \prime}$

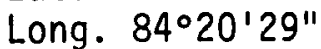

$0 . R$. Grid Block C-8

Foundation only

Dwelling

802

59.0

Anna Freels

802A

Lat. $35^{\circ} 57^{\prime} 25^{\prime \prime}$

Long. $84^{\circ} 19^{\prime} 30^{\prime \prime}$

O.R. Grid Block D-9

Present Condition: Partially standing.

Function:

Crib

Tract No.:

Size:

Acquired from:

Structure No.:

Location:

Present Condition:

Function:

804

11.0

Sarah H. Silvey heirs

804A

Lat. $35^{\circ} 57^{\prime} 45^{\prime \prime}$

Long. $84^{\circ} 19^{\prime} 32^{\prime \prime}$

0.R. Grid Block D-9

Foundation only

Dwelling

808

128.0

John and Rebecca Brown

808A

Lat. $35^{\circ} 58^{\prime} 02^{\prime \prime}$

Long. $84^{\circ} 18^{\prime} 57^{\prime \prime}$

O.R. Grid Block D-9

Present Condition:

Function:

No physical remains

Undetermined

811

Tract No.:

Size:

Acquired from:

Structure No.:

Location:

52.1

J. T. Gamble heirs

$811 \mathrm{~A}$

Lat. $35^{\circ} 58^{\prime} 17^{\prime \prime}$

Long. $84^{\circ} 18^{\prime} 33^{\prime \prime}$

O.R. Grid Block D-10

Present Condition: Foundation only

Function:
Dwelling 


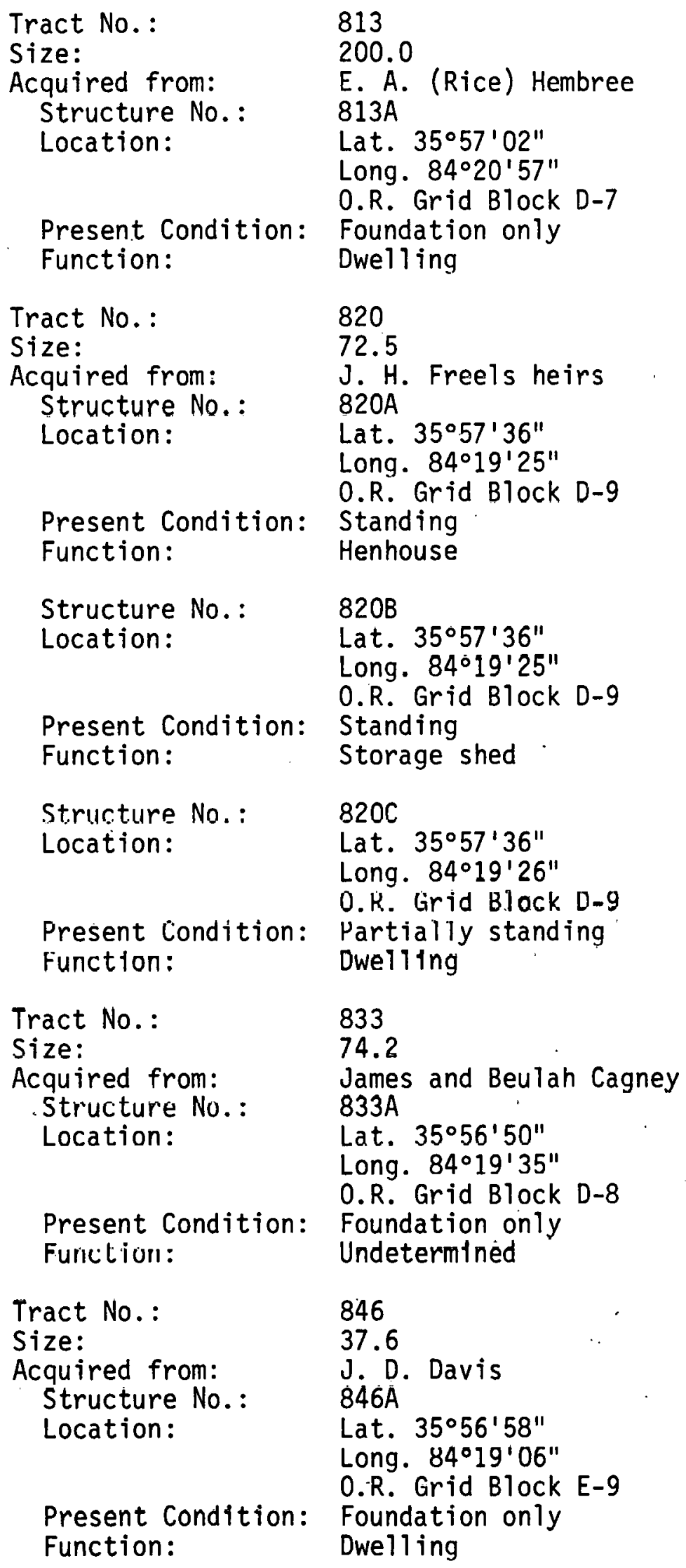


Tract No.:

849

Size:

Acquired from:

Structure No.:

108.7

Location:

W. L. and Sara Weaver

$849 A$

Lat. $35^{\circ} 57^{\prime} 13^{\prime \prime}$

Long. $84^{\circ} 18^{\prime} 48^{\prime \prime}$

O.R. Grid Block E-9

Present Condition: Foundation only

Function:

Dwelling

Structure No.:

$849 \mathrm{~B}$

Location:

Lat. $35^{\circ} 57^{\prime} 16^{\prime \prime}$

Long. 84०18'50"

O.R. Grid Block E-9

Present Condition: No physical remains

Function:

Undetermined

Tract No.:

850

Size:

201.5

Acquired from:

Structure No.:

P. G. and Zola Kite

Location:

$850 A$

Lat. $35^{\circ} 57^{\prime} 24^{\prime \prime}$

Long. $84^{\circ} 18^{\prime} 34^{\prime \prime}$

$0 . R$. Grid Block E-9

Present Condition: Foundation only.

Function:

Dwelling

Tract No.:

852

Size:

Acquired from:

Structure No.:

34.1

Location:

P. S. Beal

$852 \mathrm{~A}$

Lat. $35^{\circ} 57^{\prime} 24^{\prime \prime}$

Long. $84^{\circ} 18^{\prime} 19^{\prime \prime}$

O.R. Grid Block E-9

Present Condition: Foundation only

Function:

Undetermined

Tract No.:

853

Size:

Acquired from:

Structure No.:

53.7

J. C. Beck, Trustee

$853 \mathrm{~A}$

Location:

Lat. $35^{\circ} 56^{\prime} 51^{\prime \prime}$

Long. $84^{\circ} 18^{\prime} 41^{\prime \prime}$

Present Condition:

$0 . R$. Grid Block E-9

Function:

Standing

Dwelling

Structure No.:

853B

Location:

Lat. $35^{\circ} 56^{\prime} 51^{\prime \prime}$

Long. $84^{\circ} 18^{\prime} 41^{\prime \prime}$

0.R. Grid Block E-9

Present Condition:

Function:

Partially standirig

Crib 


\begin{tabular}{|c|c|}
\hline $\begin{array}{l}\text { ire No.: } \\
\text { on: }\end{array}$ & $\begin{array}{l}33 C \\
\text { ot. } 35^{\circ} 56^{\prime} 51^{\prime \prime} \\
\text { ong. } 84^{\circ} 18^{\prime} 41^{\prime \prime} \\
\text { R. Grid Block E-9 } \\
\text { oundation only } \\
\text { arn }\end{array}$ \\
\hline $\begin{array}{l}\text { : } \\
\text { from: } \\
\text { ire No.: } \\
\text { on: }\end{array}$ & $\begin{array}{l}856 \\
3.4 \\
\text { W. M. Currier heirs } \\
856 \mathrm{~A} \\
\text { Lat. } 35^{\circ} 55^{\prime} 23^{\prime \prime} \\
\text { Long. } 84^{\circ} 19^{\prime} 48^{\prime \prime} \\
\text { o.R. Grid Block E-6 } \\
\text { Foundation only } \\
\text { Dwelling }\end{array}$ \\
\hline $\begin{array}{l}\text { ract No.: } \\
\text { ize: } \\
\text { cquired from: } \\
\text { Structure No.: } \\
\text { Location: }\end{array}$ & $\begin{array}{l}859 \\
66.5 \\
\text { S. S. Ownby } \\
859 A \\
\text { Lat. } 35^{\circ} 55^{\prime} 15^{\prime \prime} \\
\text { Lnng. } 84^{\circ} 21^{\prime} U 7^{\prime \prime} \\
\text { 0.R. Grid Block E-6 } 6 \\
\text { Partially standing } \\
\text { Undetermined }\end{array}$ \\
\hline n: & $\begin{array}{l}859 \mathrm{~B} \\
\text { Lat. } 35^{\circ} 55^{\prime} 04^{\prime \prime} \\
\text { Long. } 84^{\circ} 21^{\prime} 01^{\prime \prime} \\
\text { 0.R. Grid Block E-6 } 6 \\
\text { Partially standing } \\
\text { Dwelling }\end{array}$ \\
\hline $\begin{array}{l}\text { ract No.: } \\
\text { ize: } \\
\text { cquired from: } \\
\text { Structure No.: } \\
\text { Location: }\end{array}$ & $\begin{array}{l}863 \\
500.0 \\
\text { R. L. Gallaher } \\
863 \mathrm{~A} \\
\text { Lat. } 35^{\circ} 57^{\prime} 08^{\prime \prime} \\
\text { Long. } 84^{\circ} 21^{\prime} 35^{\prime \prime} \\
0 . \text { R. Grid Block C-7 } \\
\text { Partially standing } \\
\text { Dwelling }\end{array}$ \\
\hline $\begin{array}{l}\text { Structure No.: } \\
\text { Location: }\end{array}$ & $\begin{array}{l}\text { 863B } \\
\text { Lat. } 35^{\circ} 57^{\prime} 16^{\prime \prime} \\
\text { Long. } 84^{\circ} 21^{\prime} 40^{\prime \prime} \\
\text { O.R. Grid Block C- } \\
\text { Foundation only } \\
\text { Dwelling }\end{array}$ \\
\hline
\end{tabular}




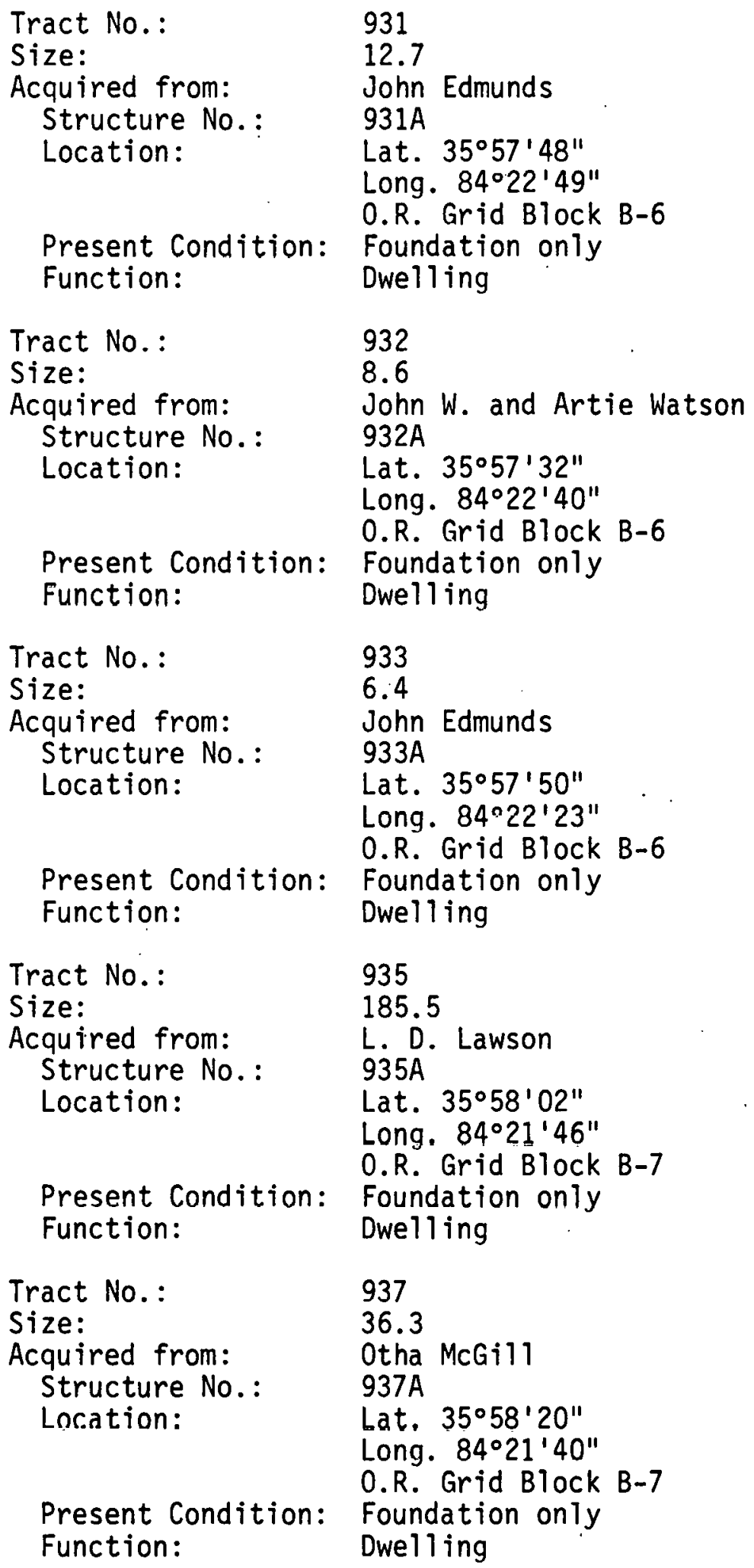


Tract No.:

939

Size:

585.6

Acquired from:

Structure No.:

Lucy E. Mountcastle

Location:

939A

Lat. $35^{\circ} 58^{\prime} 20^{\prime \prime}$

Long. $84^{\circ} 21^{\prime} 03^{\prime \prime}$

$0 . R$. Grid Block B-8

Present Condition:

Function:

Partially standing

Barn

Tract No.:

941

Size:

Acquired from:

110.0

Structure No.:

Ben and Jean Freels

Location:

\section{A}

Lat. $35^{\circ} 58^{\prime} 27^{\prime \prime}$

Long. $84^{\circ} 20^{\prime} 38^{\prime \prime}$

$0 . R$. Grid Blnck B-8

Present Condition: Foundation only

Function:

Dwelling

Structure No.:

Location:

$941 B$

Lat. $35^{\circ} 58^{\prime} 28^{\prime \prime}$

Long. $84^{\circ} 20^{\prime} 44^{\prime \prime}$

0. R. Grid Block B-8

Present Condition: Foundation only

Function:

Dwelling

Tract $\mathrm{Nn}$, :

942

Size:

Acquired from:

Structure No.:

214.7

Ed C. Browder

942A

Location:

Lat. $35^{\circ} 58^{\prime} 52^{\prime \prime}$

Long. $84^{\circ} 20^{\prime} 28^{\prime \prime}$

$0 . R$. Grid Blnck $B-9$

Present Condition: Foundation only

Function:

Dwelling

Structure No.:

942B

Location:

Lat. $35^{\circ} 58^{\prime} 47^{\prime \prime}$

Long. $84^{\circ} 20^{\prime} 55^{\prime \prime}$

$0 . R$. Grid Blnck B-B

Present Condition:

Function:

Foundation only

Dwelling

Tract No.:

953

Size:

213.2

Acquired from:

Structure No.:

Clarence Lawson 953A

Location:

Lat. $35^{\circ} 57^{\prime} 53^{\prime \prime}$

Long. $84^{\circ} 21^{\prime} 14^{\prime \prime}$

0.R. Grid Block B-7

Present Condition:

Function:

Foundation only

Dwelling 


\begin{tabular}{|c|c|}
\hline $\begin{array}{l}\text { Present Condition: } \\
\text { Function: }\end{array}$ & $\begin{array}{l}953 \mathrm{~B} \\
\text { Lat. } 35^{\circ} 57^{\prime} 55^{\prime \prime} \\
\text { Long. } 84^{\circ} 21^{\prime} 50^{\prime \prime} \\
\text { 0.R. Grid Block B-7 } \\
\text { Foundation only } \\
\text { Dwelling }\end{array}$ \\
\hline $\begin{array}{l}\text { Present Condition: } \\
\text { Function: }\end{array}$ & $\begin{array}{l}953 \mathrm{C} \\
\text { Lat. } 35^{\circ} 57^{\prime} 55^{\prime \prime} \\
\text { Long. } 84^{\circ} 21^{\prime} 50^{\prime \prime} \\
\text { O.R. Grid Block. B-7 } \\
\text { Foundation only } \\
\text { Barn }\end{array}$ \\
\hline $\begin{array}{l}\text { Tract No.: } \\
\text { Size: } \\
\text { Acquired from: } \\
\text { Structure No.: } \\
\text { Location: }\end{array}$ & $\begin{array}{l}954 \\
4.8 \\
\text { T.V. Christopher } \\
954 A \\
\text { Lat. } 35^{\circ} 58^{\prime} 05^{\prime \prime} \\
\text { Long. } 84^{\circ} 21^{\prime} 31^{\prime \prime} \\
\text { O.R. Grid Block } B-7 \\
\text { Foundation only } \\
\text { Dwelling }\end{array}$ \\
\hline $\begin{array}{l}\text { Tract No.: } \\
\text { Size: } \\
\text { Acquired from: } \\
\text { Structure No.: } \\
\text { Location: }\end{array}$ & $\begin{array}{l}961 \\
17.5 \\
\text { J. K. Rather } \\
961 A \\
\text { Lat. } 35^{\circ} 58^{\prime} 23^{\prime \prime} \\
\text { Long. } 84^{\circ} 20^{\prime} 51^{\prime \prime} \\
\text { 0.R. Grid Block B-8 } \\
\text { Foundation only } \\
\text { Dwelling }\end{array}$ \\
\hline $\begin{array}{l}\text { Tract No.: } \\
\text { Size: } \\
\text { Acquired from: } \\
\text { Structure No.: } \\
\text { Location: }\end{array}$ & $\begin{array}{l}965 \\
166-9 \\
\text { M. J. and Hoyle Low } \\
965 A \\
\text { Lat. } 35^{\circ} 58^{\prime} 36^{\prime \prime} \\
\text { Long. } 84^{\circ} 20^{\prime} 21^{\prime \prime} \\
\text { O.R. Grid Block B-9 } \\
\text { Foundation only } \\
\text { Dwelling }\end{array}$ \\
\hline $\begin{array}{l}\text { Tract No.: } \\
\text { Size: } \\
\text { Acquired from: } \\
\text { Structure No.: } \\
\text { Location: }\end{array}$ & $\begin{array}{l}973 \\
121.0 \\
\text { B. E. Crowe } \\
973 A \\
\text { Lat. } 35^{\circ} 57^{\prime} 54^{\prime \prime} \\
\text { Long. } 84^{\circ} 21^{\prime} 29^{\prime \prime} \\
\text { O.R. Grid Block B-7 } \\
\text { Foundation only } \\
\text { Undetermined }\end{array}$ \\
\hline
\end{tabular}


80

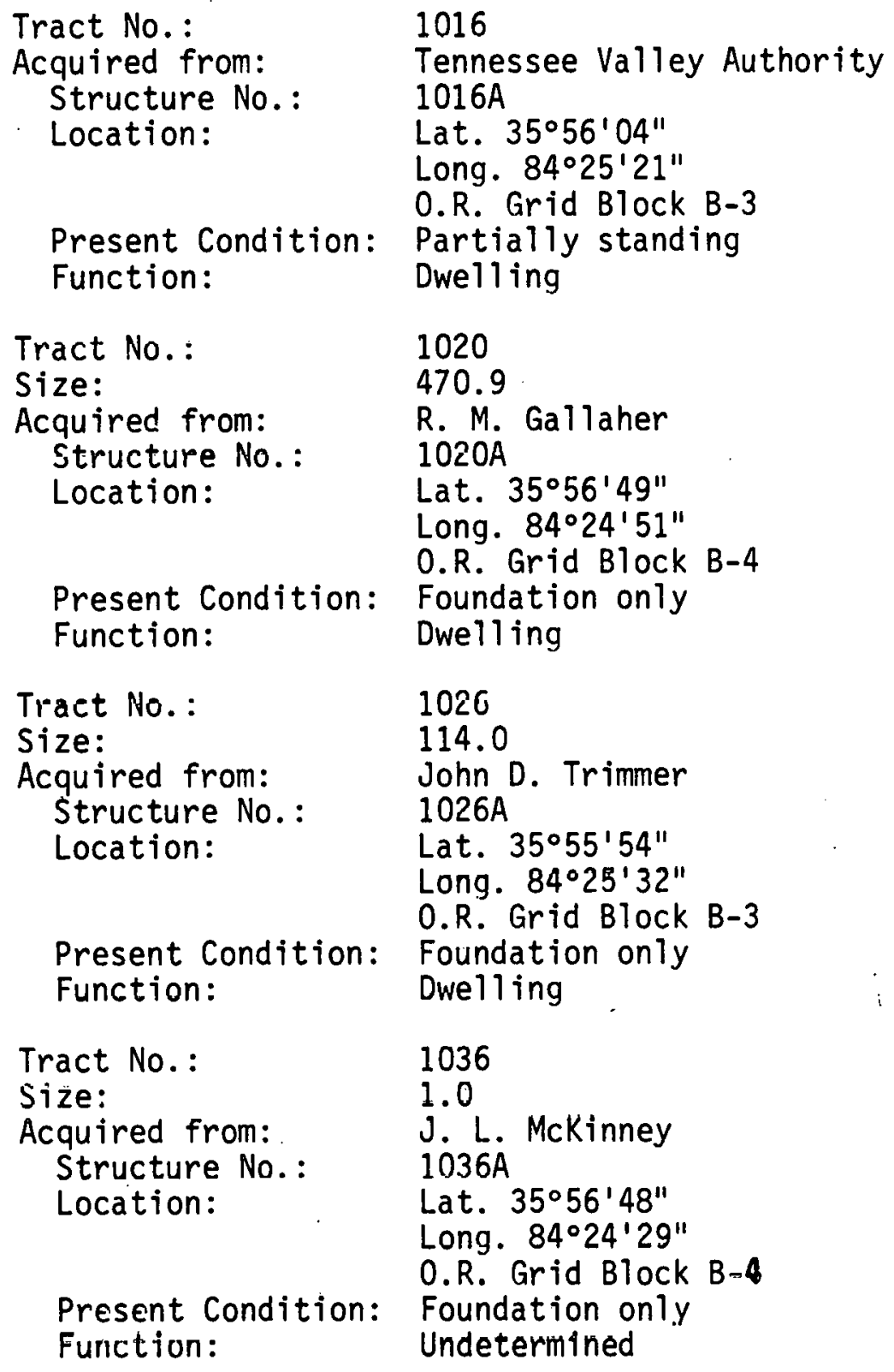




\section{APPENDIX B}

\section{COPY OF THE RECONNAISSANCE RECORDING FORM}

Reproduced below is a reduced copy of the field recording form used in this reconnaissance. It is adapted from a Canadian Inventory of Historic Buildings form kindly provided by Karlis Karklins, Canadian Historic Sites Service, National Historic Parks and Sites Branch. It is included to illustrate the detail of field information recorded. 
UNIVERSITY OF TENNESSEE

Sheet 1

HISTORIC STRUCTURES SURVEY

State:

County:

Tract:

Structure number:

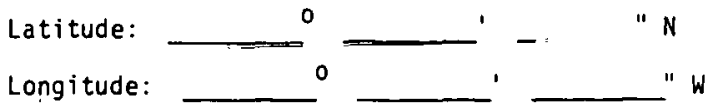

Owner:

Tenont:

Photuyraph numbers:

Date form completed:

Recurder: 
Sheet 2

Structure number:

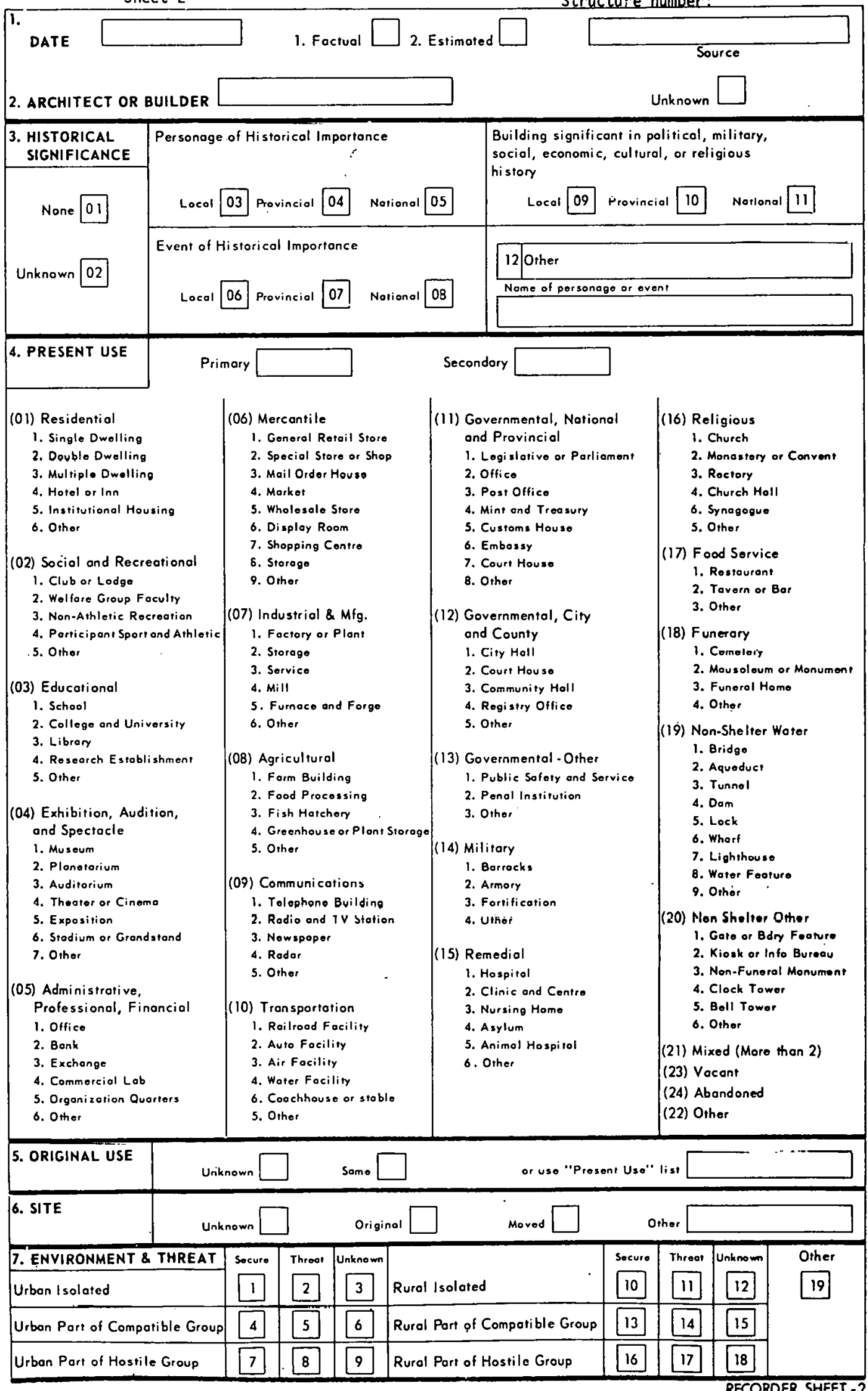


Sheet 3

Structure number:

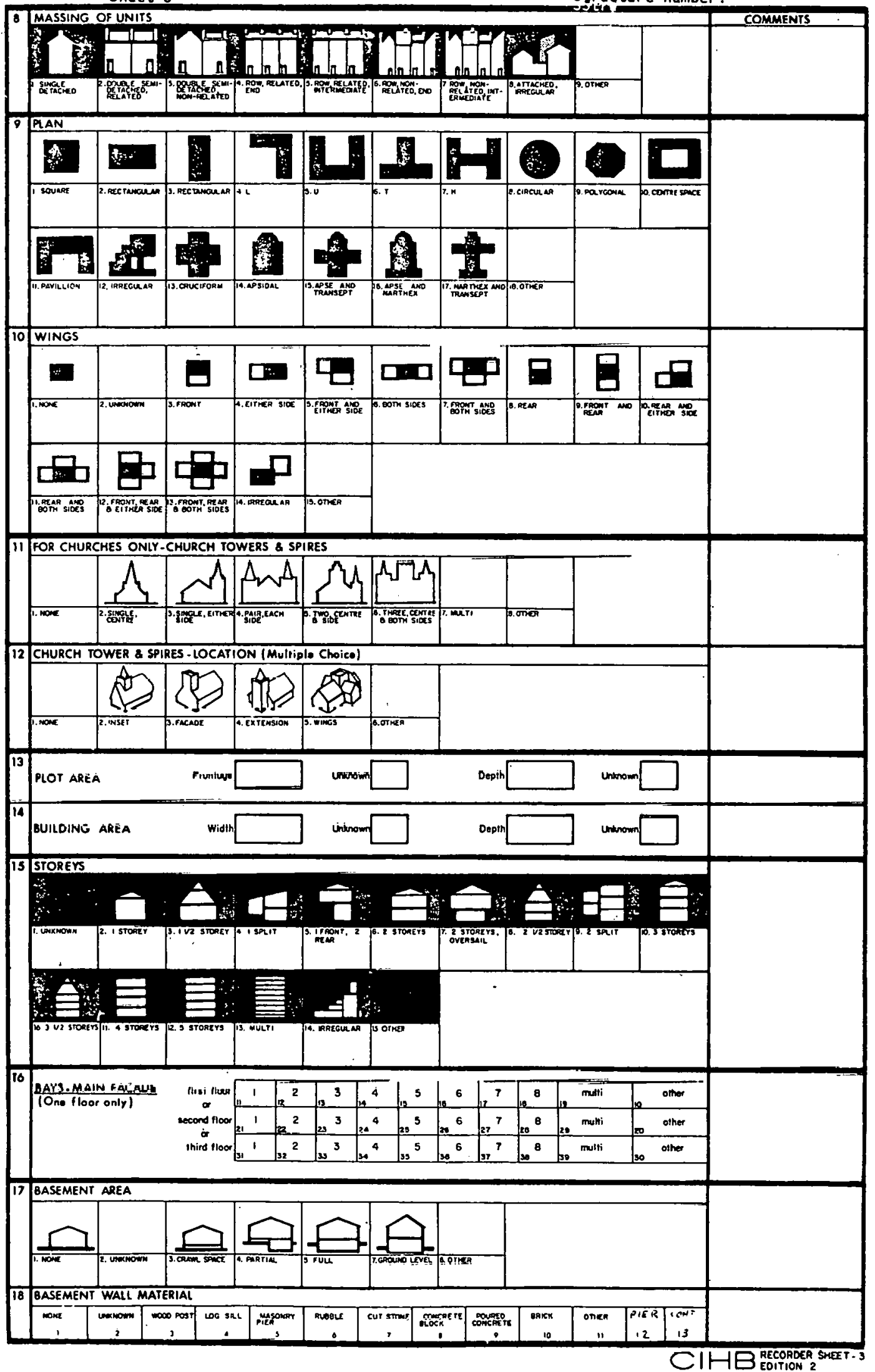


Sheeet 4

Structure number:

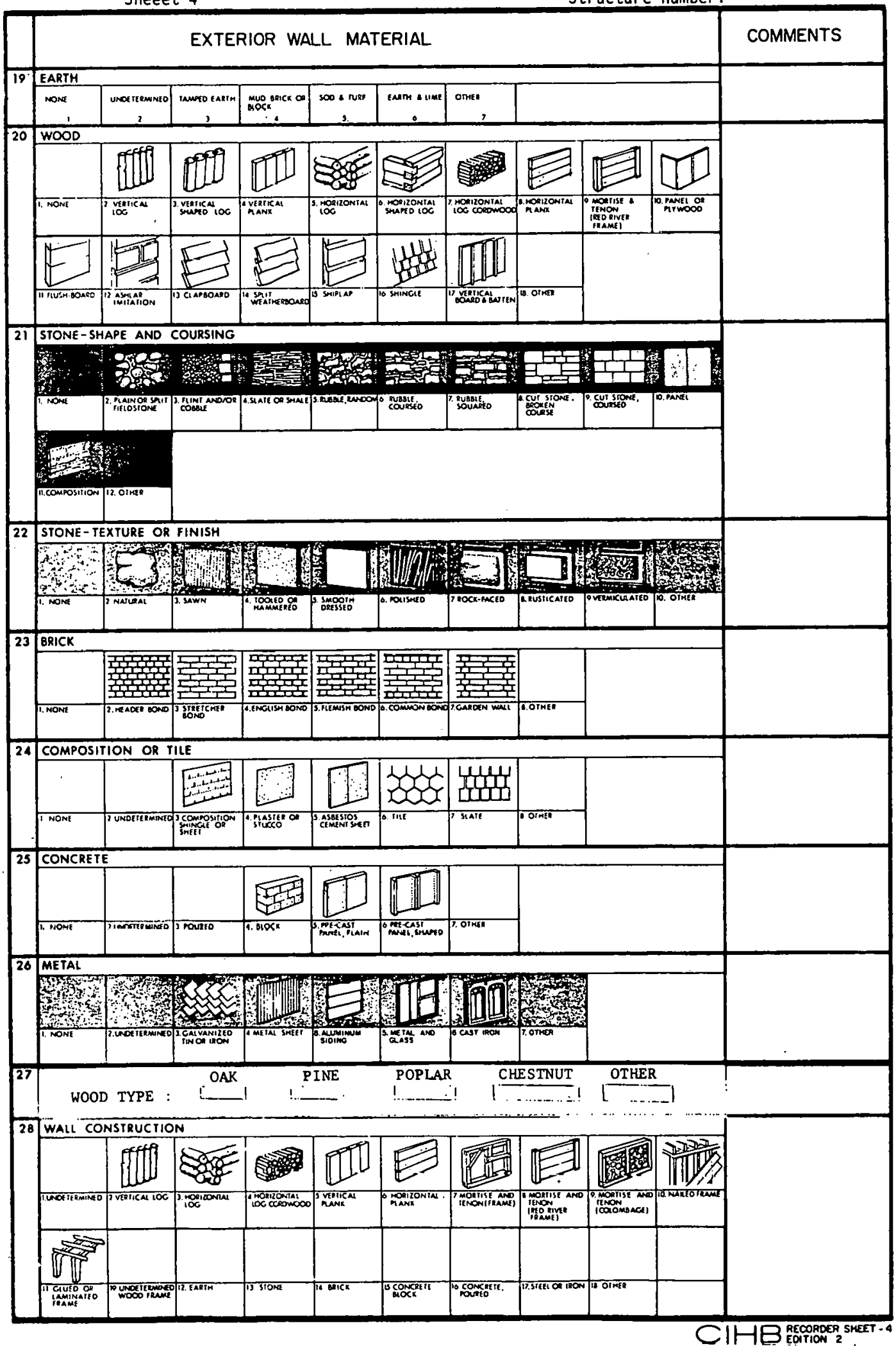


Sheet 5

Struature number

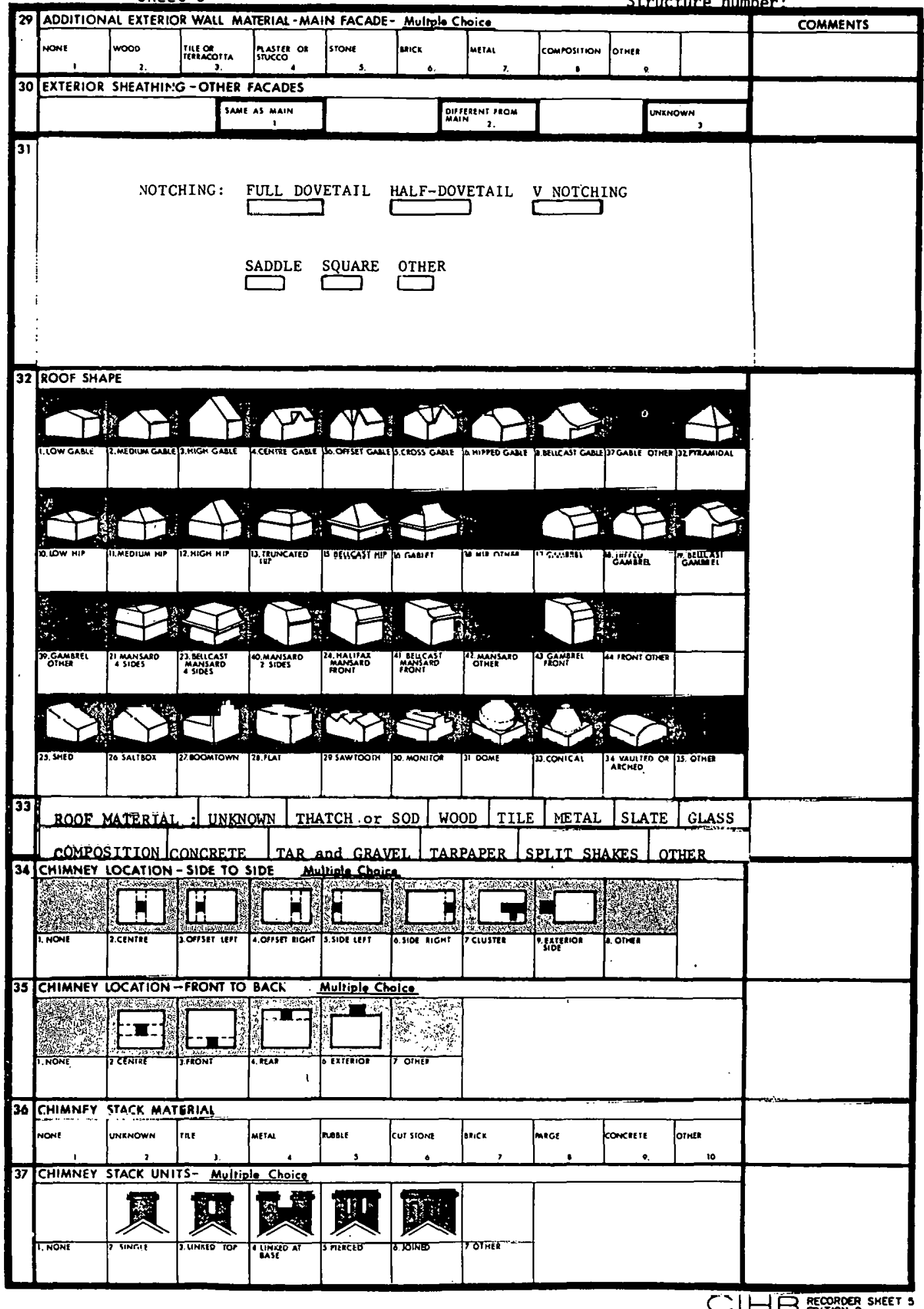

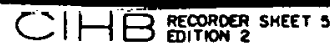


Sheet 6

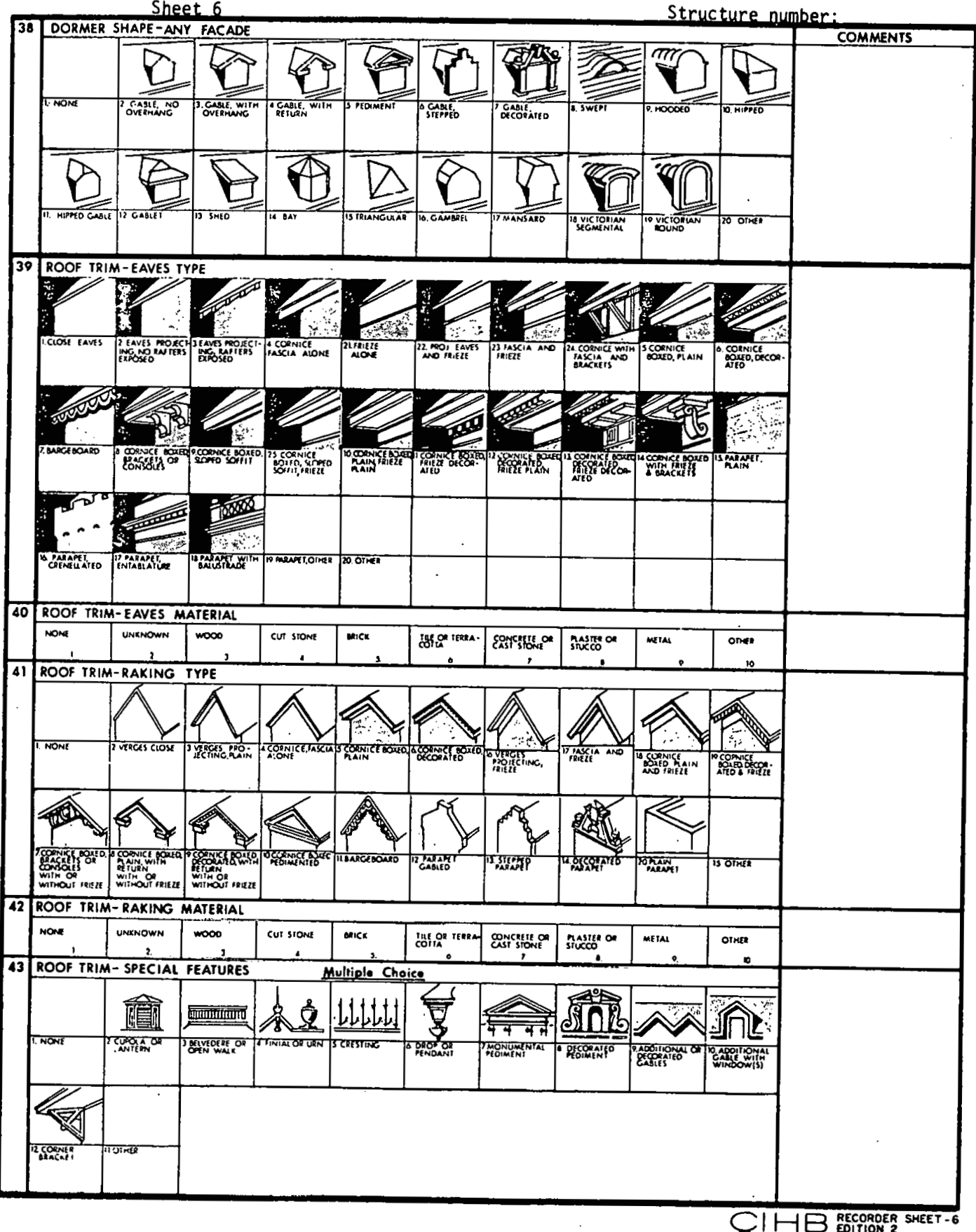


Sheet 7

Structure number:

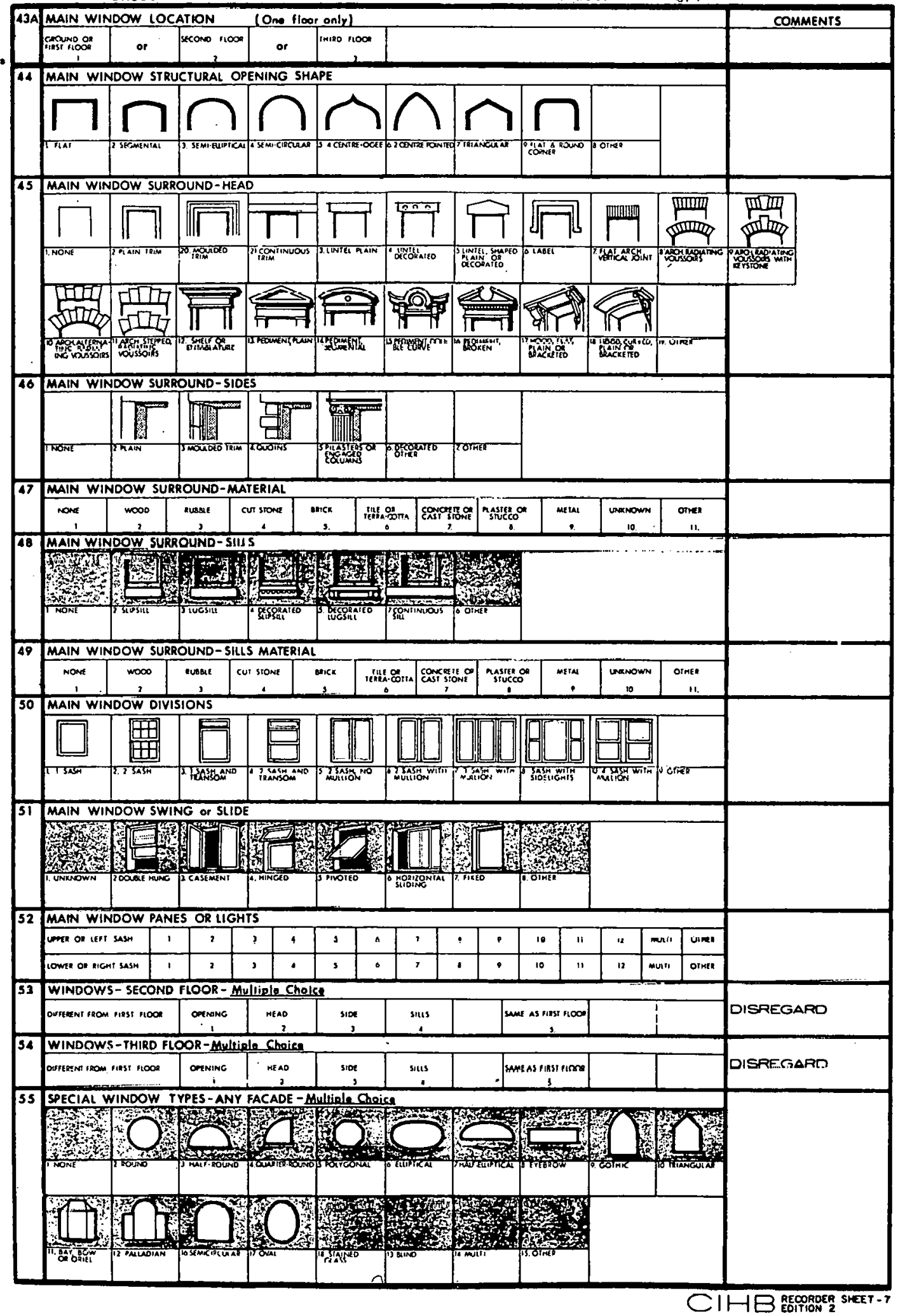


Sheet 8

Structure number:

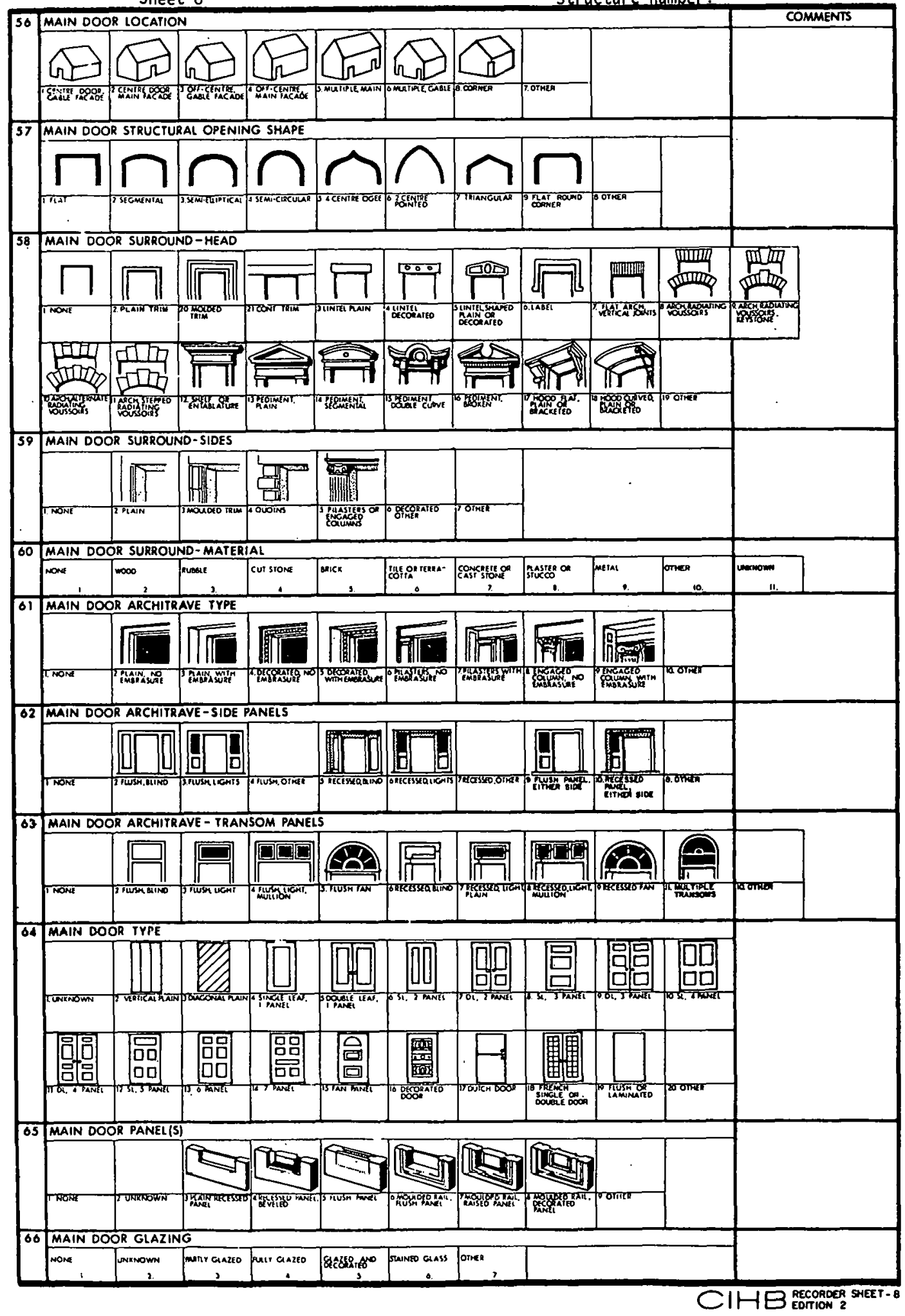


Sheet 9 Structure number:

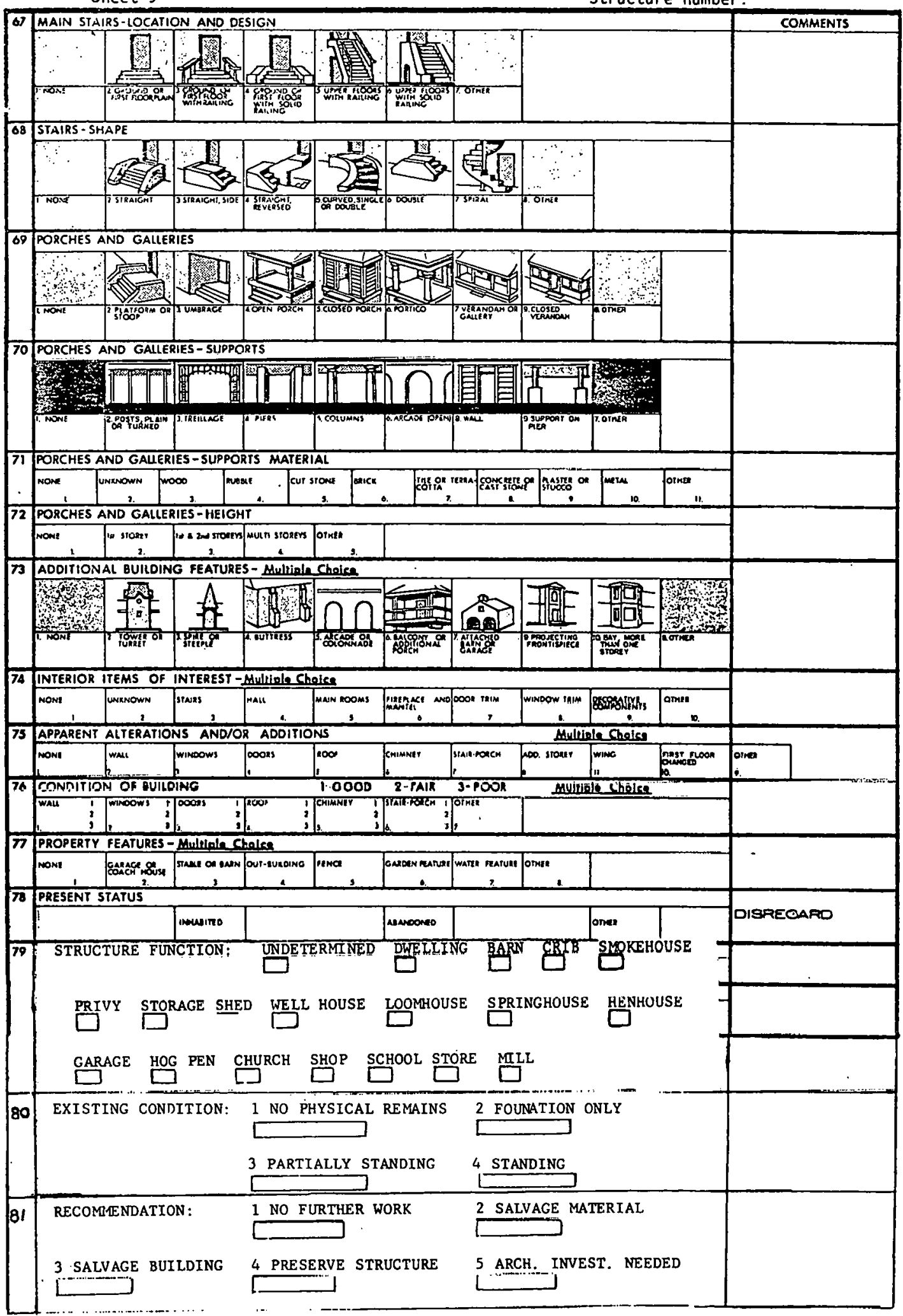


¿FOR OFFICE USE ONLY,

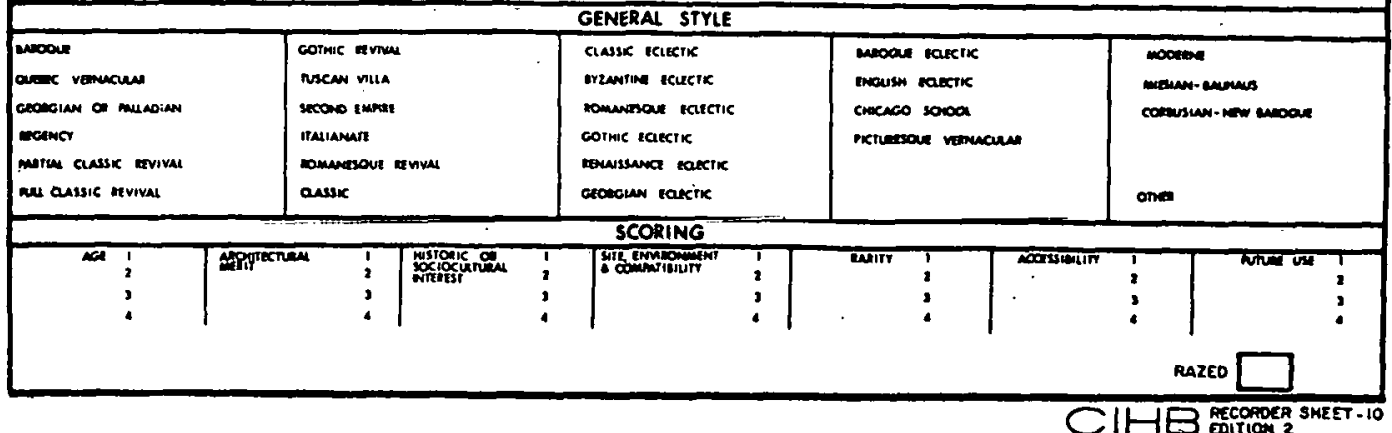


THIS PAGE

\section{WAS INTENTIONALLY LEFT BLANK}


ORNL/TM-5811

\section{INTERNAL DISTRIBUTION}

1. Biology Library

2-4. Central Research Library

5. ORNL-Y-12 Technical Library Document Reference Section

6-55. Laboratory Records Department

56. Laboratory Records, ORNL RC

57. H. H. Abee (UCC-ND)

58. H. I. Adler

59. R. G. Affel

60. H. G. Arnold

61. S. I. Auerbach

62. J. A. Auxier

63. P. C. Baker (Paducah)

64. J. A. Barker.

65. S. E. Beal1

66. M. Bender (UCC-ND)

67. D. Billen

68. C. J. Borkowski

69. C. R. Boston

70. R. W. Brocksen

71. F. K. Bruce

72-73. J. R. Buchanan

74. G. C. Cain

75. R. S. Carlsmith

76. C. M. Carter

77. J. M. Case $(Y-12)$

78. J. F. Clarke

79. W. B. Cottrell

80. J. A. Cox

81. R. B. Craig

82. F. L. C11ller

83. G. G. Fee

84. D. E. Ferguson

85. W. Fulkerson

86. J. H. Gillet te

87. R. E. Greene

88. W. F. Harris

89. R. M. Hill

90. N. E. Hinkle

91. D. G. Tarohs

92. C. Jasny (UCC-ND)

93-98. R. G. Jordan (UCC-ND)

99. S. V. Kaye

100. G. W. Keilholtz

101. J. T. Kitchings
102. D. M. Lang

103. T. A. Lincoln

104. R. S. Livingston

105. F. C. Maienschein

106. H. F. McDuffie

107. J. R. McGuffey

108. L. R. McKay

109. H. A. McLain

110. L. E. McNeese

111. J. R. McWherter

112-113. M. E. Mitchell (ORGDP)

114. J. A. Parsons $(\mathrm{Y}-12)$

115. J. H. Pashley (ORGDP)

116. E. Peelle

117. H. Postma

118. W. R. Ragland

119. D. E. Reichle

120-124. J. E. Rich

125. C. R. Richmond

126. M. W. Rosenthal

127-156. T. H. Row

157. R. M. Rush

158-159. Merwyn Sanders (Y-12)

160. H. E. Seagren

161. M. J. Skinner

162. I. G. Speas

163. R. L. Spore

164-165. S. S. Stief (ORGDP)

166. W. G. Stockdale

167. J. F. Strickland (Y-12)

168. J. W. Strohecker $(Y-12)$

169. E. G. Struxness

170. R. E. Thoma

171. D. B. Trauger

172-173. G. U. U1rickson

174. P. R. Vanstrum (UCC-ND)

175. J. R. Weir, Jr.

176. W. H. Wilcox

177. M. K. Wilkinson

178. R. A. Winkel (ORGDP)

179. E. J. Witkowski

180. H. E. Zitte1

181. A. Zucker 
EXTERNAL DISTRIBUTION

182. William Bass, Department of Anthropology, University of Tennessee, Knoxville, TN 37916

183. Merle Byrd, UT-ERDA, CARL, Oak Ridge, TN 37830

184. J. D. Cape, Technical Information Center, Oak Ridge, TN 37830

185. Jefferson Chapman, Department of Anthropology, University of Tennessee, Knoxville, TN 37916

186-187. Stephen Cooper, Department of Anthropology, University of Tennessee, Knoxville, TN 37916

188. J. J. Davis, Office of Nuclear Regulatory Research, U.S. NRC, Washington, $D C 20555$

189. B. Dixon, Department of Anthropology, University of Témuessee, Knoxville, 'l'N 37916

190. V. S. Emler, Goodyear Atomic Corporation, P.0. Box 628, Piketon, $\mathrm{OH} 45661$

191. C. H. Faulkner, Department of Anthropology, University of Tennessee, Knoxville, TN. 37916

192-193. Richard Faust, Department of Anthropology, University of Tennessee, Knoxville, TN 37916

194-208. George Fielder, State of Tennessee, 170 2nd Avenue N, Nashville, TN 37201

209. F. A. Gartrell, Tennessee Valley Authority, Chattanooga, TN

210. F. A. Gifford, NOAA, Oak Ridge, TN 37830

211. I. T. Glover, Oak Ridge Associated Universities, Oak Ridge, TN 37830

212. A. K. Guthe, עeparrtmènt of Anthropology, University of Tennessee, Knoxville, TN 37916

213. T. H. Hardin, U,S. ERDA, Oak Ridge, TN 378.30

214. B. Harrington, Department of Anthropolngy, Iniversity of Tennessee, Knoxville, TN 37916

215-216. Victor Hood, Department of Anthropology, University of Tennessee, Knoxvilie, TN 37916

217. R. Jantz, Department of Anthropology, University of Tennessee, Knoxville, TN 37916

218. E. B, Kiser, U.S. ERDA, Oak. Ri.dge, TN 37830

219. E. A. Kraemer, Rust Engineering Company, Oak Ridge, TN 37830

220. J. A. Lenhard, U.3. ERDA, Odk Rldge, TN 37830

221. R. C. Lipman, Rust Engineering Company, Oak Ridge, TN 37830

222. J. L. Liverman, Assistant Administrator for Environmental Safety, U.S. ERDA, Washington, DC 20545

223. T. W. Martin, Oak Ridge Associated Universities, Oak Ridge, TN 37830

224-225. M. C. R. McCollough, Department of Anthropology, University of Tennessee, Knoxville, TN 37916

226-227. D. Muller, Office of Nuclear Reactor Regulation, U.S. NRC; Washington, DC 20555

228. P. Parmalee, Department of Anthropology, University of Tennessee, Knoxville, TN 37916 
229. A. F. Pennak, National Lead Company of Ohio, P.0. Box 39158, Cincinnati, OH 45239

230. W. H. Pennington, Division of Biomedical Environmental Research, U.S. ERDA, Washington, DC 20545

231. R. P. Polhemus, Department of Anthropology, University of Tennessee, Knoxville, TN 37916

232. W. G. Pollard, Oak Ridge Associated Universities, Oak Ridge, TN 37830

233. W. Range, U.S. ERDA, Oak Ridge, TN 37830

234. N. F. Riedl, Department of Anthropology, University of Tennessee, Knoxville, TN 37916

235. Donald Robie, UT-ERDA, CARL, Oak Ridge, TN 37830

236. I. C. Roberts, Office of Standards Development, U.S. NRC, Washington, DC 20555

237-246. J. W. Ruch, Oak Ridge Historical Society, Oak Ridge, TN 37830

247. G. F. Schroedl, Department of Anthropology, University of Tennessee, Knoxville, TN 37916

248. D. D. Sheahan, Rust Engineering Company, Oak Ridge, TN 37830

249. R. Sprague, Department of Anthropology, University of Tennessee, Knoxville, TN 37916

250. P. M. Thomas, Department of Anthropology, University of Tennessee, Knoxville, TN 37916

251. W. H. Travis, U.S. ERDA, Oak Ridge, TN 37830

252. Peter S. Van Nort, General Manager, Project Management Corp., CRBRP, Oak Ridge, TN 37830

253. H. E. Walburg, UT-ERDA, CARL, Oak Ridge, TN 37830

254. M. Warde11, Catalytic Construction Co., Oak Ridge, TN 37830

255. J. F. Wing, U.S. ERDA, Oak Ridge, TN 37830

256. C. L. Yarbro, Jr., U.S. ERDA, Oak Ridge, TN 37830

257-258. Department of Anthropology, Library, University of Tennessee, Knoxville, TN 37916

259. Museum of Atomic Energy Commission, Oak Ridge, TN 37830

260-263. Oak Ridge Public Library, Oak Ridge, TN 37830

264-290. Technical Information Center, U.S. ERDA, Oak Ridge, TN 37830 